\title{
Compelled Expression and the Public Forum Doctrine
}

Howard M. Wasserman

Florida State University, howard.wasserman@fiu.edu

Follow this and additional works at: https://ecollections.law.fiu.edu/faculty_publications

Part of the Constitutional Law Commons, First Amendment Commons, and the Legal History Commons

\section{Recommended Citation}

Howard M. Wasserman, Compelled Expression and the Public Forum Doctrine, 77 Tul. L. Rev. 163 (2002). Available at: https://ecollections.law.fiu.edu/faculty_publications/74 


\section{HEINONLINE}

Citation: 77 Tul. L. Rev. 163 2002-2003

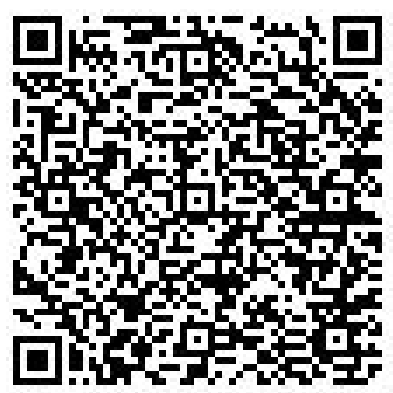

Content downloaded/printed from

HeinOnline (http://heinonline.org)

Tue Nov 11 18:11:07 2014

-- Your use of this HeinOnline PDF indicates your acceptance of HeinOnline's Terms and Conditions of the license agreement available at http://heinonline.org/HOL/License

-- The search text of this PDF is generated from uncorrected OCR text.

-- To obtain permission to use this article beyond the scope of your HeinOnline license, please use:

https://www.copyright.com/ccc/basicSearch.do?

\&operation $=$ go\&search $\mathrm{Type}=0$

\&lastSearch $=$ simple\&all=on\&titleOrStdNo=0041-3992 


\title{
Compelled Expression and the Public Forum Doctrine
}

\author{
Howard M. Wasserman*
}

\begin{abstract}
This Article analyzes the theory underlying the First Amendment protection against being compelled by government to utter, present, or fund unwanted expression. The author creates a three-part model for determining when the free speech rights of an objecting payer have been triggered. Under that model, First Amendment rights are implicated when there has been an actual government compulsion requiring an individual to give money to, or for the express benefit of, a specific private speaker for some use that, in itself, should be understood as expressive. This model strikes a necessary balance between the important theoretical underpinnings of the protection against being compelled financially to support private speech and the First Amendment commitment to the dissemination of the maximum amount of individual expression.

The model shows how to resolve First Amendment challenges to the use of governmentcompelled funding of public forums-including streets and parks, public University student activities fee programs, and the National Endowment for the Arts-when those forums are used by objectionable speakers or for offensive speech. The key is that the payer is not compelled to fund any objectionable speech or speaker. The payer funds only the public forum, the physical place and services associated with that place or the pool of money in the subsidy program, none of which is expressive. Under this model, all compelled-expression challenges to the establishment and funding of public fonms must fail.
\end{abstract}

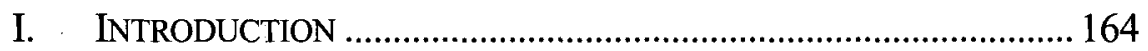

II. COMPELLED EXPRESSION: AN OVERVIEW ………...................... 169

A. Categories of Compelled Expression ................................. 169

1. Compelled Utterance or Presentation of Message ..................................................................... 169

2. Compelled Subsidization of Private Expression...... 174

3. Compelled Subsidization of Expression Pursuant to Government Programs.

4. Compelled Subsidization of Government's Expressive and Nonexpressive Activities 182

B. Theoretical Bases of Compelled Expression .....................190

1. Individual Liberty ....................................................... 190

2. Marketplace of Ideas .................................................... 193

C. Limiting the Category of Compelled Expression.............. 196

1. Funds Used for Expression .......................................201

* Visiting Assistant Professor, Florida State University College of Law. B.S. 1990, J.D. 1997, Northwestern University. My thanks to Steven Gey, Paul LeBel, Peter Oh, Martin Redish, and Nat Stern for their reviews and comments on earlier drafts of this Article. 
2. Disagreement with the Message Funded 202

3. Public Connection Between the Funder and the Message 204

III. A LIMITING TEST FOR COMPELLED EXPRESSION ........................206

IV. OBJECTORS' RIGHTS IN A NEW CONTEXT ..................................210

A. Background and Lower Courts.......................................210

B. Southworth in the Supreme Court.....................................2213

C. Problems with the Court's Approach to Southworth .........215

V. OBJECTING PAYERS' RightS IN THE PUBLIC ForUM ....................220

A. Student Activities Funds as Public Forums.......................220

1. Southworth Reconsidered .........................................220

2. Objector's Rights in the Public Forum........................ 228

B. Application of the Compelled-Expression Doctrine to Public Forums................................................................... 231

C. Other Explanations for the Denial of Objector's

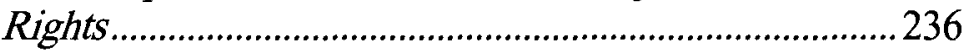

1. Justice Souter ........................................................2236

2. Robert Kamenshine................................................... 238

3. Lackland Bloom ......................................................241

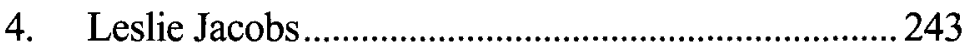

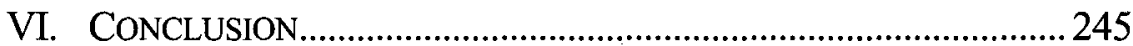

\section{INTRODUCTION}

Hard cases make bad law. ${ }^{1}$ So do easy cases, ${ }^{2}$ particularly when no one realizes that they are easy. ${ }^{3}$ Board of Regents of the University of Wisconsin System v. Southworth (Southworth)" resides in that last neighborhood.

Several students at the University of Wisconsin challenged the University's mandatory student fee system, under which each student was required to pay a fee to the University, which money was placed in a common pool, administered by the student government, and distributed to registered student organizations for various political,

1. See Bd. of County Comm'rs v. Umbehr, 518 U.S. 668, 710 (1996) (Scalia, J., dissenting) ("They say hard cases make bad law.").

2. See Hudson v. United States, 522 U.S. 93, 106 (1997) (Stevens, J., concurring) ("The maxim that 'hard cases make bad law' may also apply to easy cases."); see also H.L.A. HART, THE CONCEPT OF LAW 129 (2d ed. 1994) (warning that in "plain case[s]" flexibility and social goals may be sacrificed when rules are applied formalistically).

3. See Ankenbrandt v. Richards, 504 U.S. 689, 717 n.* (1992) (Stevens, J., concurring) ("An easy case is especially likely to make bad law when it is unnecessarily transformed into a hard case.").

4. 529 U.S. 217 (2000), rev'g Southworth v. Grebe, 151 F.3d 717 (7th Cir. 1998). 
ideological, and expressive activities. ${ }^{5}$ The paying students argued that the program violated their First Amendment rights by compelling them to fund offensive or objectionable private speech. ${ }^{6}$ Southworth marked an odd application of the compelled-expression doctrine, which initially prohibited government from requiring individuals to utter or present the government's own political message, and was extended to prohibit government from compelling individuals to utter or present the message of a private speaker ${ }^{8}$ or to pay money to private speakers so they may present that message.' The United States Supreme Court largely rejected the plaintiffs' free speech claims, holding that as long as the university student activities fund was operated in a viewpointneutral manner, as Wisconsin's program unquestionably was, the free speech rights of the objecting students were sufficiently protected. ${ }^{10}$

The conclusion was undoubtedly correct. But the Court failed to recognize a key point. The university student activities fund was a metaphysical public forum, akin to a street, park, or municipal auditorium, established by government for use by private speakers."

5. See Southworth, 529 U.S. at 220-26; Grebe, 151 F.3d at 718-21.

6. See Southworth, 529 U.S. at 220-27.

7. See Wooley v. Maynard, 430 U.S. 705, 717 (1977) (“[W]here the State's interest is to disseminate an ideology, no matter how acceptable to some, such interest cannot outweigh an individual's First Amendment right to avoid becoming the courier for such message."); W. Va. State Bd. of Educ. v. Barnette, 319 U.S. 624, 635-36 (1943) (striking down state-imposed requirement of school flag salute and recitation of Pledge of Allegiance in public schools, where ceremony touches on matters of opinion and political attitude); David B. Gaebler, First Amendment Protection Against Government Compelled Expression and Association, 23 B.C. L. Rev. 995, 997-1000 (1982); Leslie Gielow Jacobs, Pledges, Parades, and Mandatory Payments, 52 RUTGERS L. Rev. 123, 131 (1999).

8. See Hurley v. Irish-Am. Gay, Lesbian \& Bisexual Group, Inc., 515 U.S. 557, 559 (1995) (holding that a state violates the First Amendment when it requires private citizens who organize a parade to include among the marchers a group imparting a message that the organizers do not wish to convey).

9. See United States v. United Foods, Inc., 533 U.S. 405, 415 (2001) ("We have not upheld compelled subsidies for speech in the context of a program where the principat object is speech itself."); Keller v. State Bar of Cal., 496 U.S. 1, 4-5 (1990) (holding that the state bar, in which membership was required as a condition of practicing law in the state, could not spend dues on certain ideological and political activities to which individual dues payers were opposed); Abood v. Detroit Bd. of Educ., 431 U.S. 209, 235-36 (1977) (holding that the Constitution prohibits a union from financing nongermane political expenditures with dues, fees, or payments collected from objecting dues payers); Jacobs, supra note 7, at 136-38.

10. See Southworth, 529 U.S. at 233-34; infra notes 268-280 and accompanying text.

11. See Randall P.'Bezanson \& William G. Buss, The Many Faces of Government Speech, 86 IOWA L. REV. 1377, 1424 (2001) (arguing that Southworth involved something that "looked a lot like a public forum"); Norman L. Cantor, Forced Payments to Service Institutions and Constitutional Interests in Ideological Non-Association, 36 RUTGERS L. REV. 3, 46-47 (1983) (arguing that the collected pool of student fees is an expressive forum to which students have access); Leslie Gielow Jacobs, The Link Between Student Activity Fees and Campaign Finance Regulations, 33 IND. L. REv. 435, 455-56 (2000) (arguing that the 
This follows for three reasons. First, the program, designed to provide resources for private student expression, is an instrumentality of communication, a program specifically used for the communication of information and ideas, therefore subject to analysis as a public forum. ${ }^{12}$ Second, this conclusion necessarily follows from the Court's earlier decision in Rosenberger $v$. Rector \& Visitors of University of Virginia, in which the Court held that a student activities fund-one materially identical to the fund at issue in Southworth-was a "forum more in a metaphysical than in a spatial or geographic sense, but the same principles are applicable."13 Third, the conclusion follows from recognizing that the University could have collected the same student fees to build and maintain an on-campus park, stage, or auditorium, unquestionably a public forum, for expressive use by student organizations. $^{14}$ Remarkably, however, the Southworth majority ignored Rosenberger and stated that the student activities fund is "not a public forum in the traditional sense of the term."

The issue in the Southworth litigation should have been defined as whether a payer may object to having her compelled funds used to establish, fund, and maintain a public forum where that forum is used by speakers to whom the payer objects or to present messages with which she disagrees. The answer to that question is no.

This potential application of the compelled speech doctrine provides a vehicle through which to undertake a broad examination of the theory of compelled expression. ${ }^{16}$ The recognition of an objecting payer's right with respect to the student activities fund and other public forums results in burdens on, and the closing of, places and programs designed to broaden public discourse and to facilitate private

university student activities fees fund is a speech forum); infra notes 309-340 and accompanying text.

12. See Steven G. Gey, Reopening the Public Forum-From Sidewalks to Cyberspace, 58 OнIO ST. L.J. 1535, 1576 (1998); infra notes 326-328 and accompanying text.

13. 515 U.S. 819,830 (1995); Gey, supra note 12, at 1603 (arguing for taking the notion of a metaphysical public forum seriously and applying the same reasoning for physical property public forum disputes to public subsidy cases); see infra notes $310-322$ and accompanying text.

14. See Southworth v. Grebe, 157 F.3d 1124, 1129 (7th Cir. 1998) (Wood, D., J., dissenting from denial of rehearing en banc) ("It is the same as if they simply built a large auditorium and held it open for everyone."); infra notes 323-325 and accompanying text.

15. See Southworth, 529 U.S. at 230; Bezanson \& Buss, supra note 11, at 1424 (stating that the Court tried hard to avoid characterizing the student activities fund as a public forum).

16. For purposes of simplicity, the general term "compelled expression" refers both to situations in which an individual is forced to utter or present a particular message and in which she is compelled to fund a private message or messenger. 
expression, resulting in an overall loss of speech in the marketplace. ${ }^{17}$ It is imperative that we sharply, clearly, and narrowly define the contours of the right against compelled expression and of what we understand as instances of compelled funding of expression. ${ }^{18}$ Not every compelled payment from an individual qualifies as compelled expression. Instead we must establish obvious lines to determine when an individual is, in fact, being compelled to utter, present, or support private speech she does not wish to utter, present, or support.

The solution is to devise a test for when the right against compelled financial support for expression has been triggered that incorporates certain necessary limiting principles. This model asks whether the compelled payer is (1) required or compelled by the relevant governmental body (through law, regulation, or fiat), (2) to give money to, or for the express benefit of, a private recipient, (3) for that recipient's expressive activities. The objecting payer's right will be triggered only if the funds are mandated by government and go directly from the payer to, or for the specific and express benefit of, a particular private speaker for immediate uses that are expressive. ${ }^{19}$

17. See Bezanson \& Buss, supra note 11, at 1427 (arguing that recognizing the objecting payer's claim "requires a remedial means that is unworkable because any system requiring optional fees or a way for students to opt out from paying for specified activities would be disruptive and expensive and thus ineffective"); Abner S. Greene, Government of the Good, 53 VAND. L. REv. 1, 13 (2000) ("[W]hile it is possible to issue pro rata refunds of the dues of nonunion members, it would be impossible (i.e., prohibitively costly) to do the same for taxpayer refunds."); see also THOMAS 1. EMERSON, THE SYSTEM OF FREEDOM OF EXPRESSION 645 (1970) ("One important way in which the government can affirmatively promote a system of freedom of expression is by making available to individuals and groups the facilities for engaging in expression."); Leslie Gielow Jacobs, The Public Sensibilities Forum, 95 Nw. U. L. REv. 1357, 1366 (2001) ("The permissible range of government action is different when it promotes speech, rather than restricts it."); Jacobs, supra note 11, at 456 (" $[W]$ here the government creates and structures a public forum, its speech-conscious action may serve rather than thwart free speech clause values.").

18. The First Amendment protection from compelled funding of expression rests on the premise, which we accept, that money, when spent for expressive purposes, is expressive and implicates free speech concerns and that compelling an individual to fund speech is the same as compelling that individual to speak. See Jacobs, supra note 11, at 451-52; see also United States v. United Foods, Inc., 533 U.S. 405, 410 (2001) ("Just as the First Amendment may prevent the government from prohibiting speech, the Amendment may prevent the government from ... compelling certain individuals to pay subsidies for speech to which they object." (internal citation omitted)); Abood v. Detroit Bd. of Educ., 431 U.S. 209, 234 (1977) ("[C]ontributing to an organization for the purpose of spreading a political message ... 'implicate[s] fundamental First Amendment interests."' (quoting Buckley v. Valeo, 424 U.S. 1, 23 (1976))). But see United Foods, 533 U.S. at 425 (Breyer, J., dissenting) ("[The program] does not compel speech itself; it compels the payment of money. Money and speech are not identical.").

19. See discussion infra Part III. 
This model establishes the reasoning that the Court should have used to reject the objecting students' challenge to the public university student activities fund in Southworth, as well as future challenges to mandatory fees and assessments used to fund all public forums, physical and metaphysical, within and without the university setting. No payer in any political community has a right to object to the use of her funds to establish and maintain a physical or metaphysical public forum, regardless of the speech occurring in and through that forum. The reason is that no speech is, in fact, funded with those compelled payments; only the forum, the physical place or the pool of money, is funded. A forum, in and of itself, is not expressive. ${ }^{20}$ Whatever private speech ultimately occurs in and through that forum is irrelevant to the payer's claim. Moreover, the immediate recipient of the funds in public forum cases is the governmental body that establishes and maintains the forum, not the private speaker who uses it; payers have no right to object to any governmental expenditures of compelled funds, whether that expenditure is expressive or nonexpressive. ${ }^{21}$

Part I of this Article reviews the doctrine and theory underlying the First Amendment freedom from compelled expression. We examine four categories of compelled-expression cases, as well as the theoretical issues underlying the protection. We also examine the need for limiting principles on the scope of what is understood as compelled financial support for private speech. Part II establishes our controlling model for determining whether a compelled payer's free speech right has been triggered. Part III discusses the Southworth litigation, considering the problems with, and effects of, the Supreme Court's analysis. Part IV explains how the Court should have addressed and resolved Southworth, based on the recognition that the student activities fund is a public forum and that the First Amendment right to object is not triggered when one is compelled to fund such a public forum. We then apply the three-part model to show why objecting payers' rights are not triggered by the compulsion to fund either the student activities fund in Southworth or any other public forumbecause funding a public forum entails funding not private expression, but a nonexpressive government program, to which a payer may not object on First Amendment grounds.

20. See Greene, supra note 17, at 14 ("It is the open forum that is funded ...."); infra notes 353-366 and accompanying text.

21. See infra notes 115-152 and accompanying text. 


\section{COMPELLED EXPRESSION: AN OVERVIEW}

\section{A. Categories of Compelled Expression}

The jurisprudence and commentary on compelled expression recognize several categories or factual situations potentially implicating the right against compelled expression. All rest on similar underlying premises and justifications, although the applicable rules may differ. We consider four categories:

1. compelled utterance or presentation of a message;

2. compelled subsidization of private expression;

3. compelled subsidization of private expression pursuant to a government program; and

4. compelled subsidization of government's expressive and nonexpressive activities. ${ }^{22}$

\section{Compelled Utterance or Presentation of Message}

The first and most obvious example of compelled expression is actual compulsion to speak - a governmental requirement that an individual utter or present some statement or message to the public, usually a message approved and supported by the government. ${ }^{23}$ This category originated in West Virginia Board of Education v. Barnette, where the Court addressed the constitutionality of a World War II law requiring public school students to salute the flag and recite the Pledge of Allegiance as part of the school's educational program. ${ }^{24}$ The

22. We do not discuss two other compulsion situations raising First Amendment concerns, which are less applicable to the public forum context. One is forced expressive association. See, e.g., Boy Scouts of Am. v. Dale, 530 U.S. 640, 659 (2000) (holding that the Boy Scouts could not be required under state public accommodations law to admit homosexual scoutmaster); see also Martin H. Redish \& Christopher R. McFadden, HUAC, The Hollywood Ten, and the First Amendment Right of Non-Association, 85 MINN. L. REV. 1669, 1689 (2001) (exploring the First Amendment connections between Dale and the blacklisting of the Hollywood Ten in the early 1950s); David E. Bernstein, The Right of Expressive Association and Private Universities' Racial Preferences and Speech Codes, 9 WM. \& MARY BILL RTS. J. 619, 629-38 (2001) (analyzing free speech under university diversity rules). A second is compelled access to privately owned speech forums, such as media outlets. See, e.g., Turner Broad. Sys., Inc. v. FCC, 520 U.S. 180, 185 (1997) (holding that the requirement that cable systems carry broadcast networks is consistent with the First Amendment); Miami Herald Publ'g Co. v. Tornillo, 418 U.S. 241, 258 (1974) (holding that the choice of material to go into a newspaper constitutes editorial discretion not subject to governmental regulation consistent with the First Amendment).

23. See Robert D. Kamenshine, Reflections on Coerced Expression, 34 LAND \& WATER L. REv. 101, 102 (1999) ("[G]overnment had directed human beings to express, by mouth and/or by a communicative physical act, a defined political or religious viewpoint.").

24. 319 U.S. 624, 626-27 \& n.2 (1943); see also Jacobs, supra note 7, at 123 ("It all started with the pledge of allegiance."). 
plaintiffs were parents of students who were Jehovah's Witnesses, who believed that the American flag was an image that their religious beliefs forbade them to salute or otherwise worship. ${ }^{25}$ Three years earlier, the Court had upheld a similar flag-salute requirement. ${ }^{26}$

The Barnette Court began by noting that the sole conflict was between state authority and the right of the individual to selfdetermination in matters that touch individual opinion and personal attitude; there was no interference with the rights of others, who remained free to recite the pledge themselves. ${ }^{27}$ Second, while government could instill patriotism and loyalty to country through education and instruction in the history and structure of government, the issue was whether it could compel the declaration of that loyalty. ${ }^{28}$ Third, the flag had meaning as a symbol of adherence to government and the salute and pledge required the individual to communicate by word and deed the acceptance of the political ideas the flag bespeaks. ${ }^{29}$ Moreover, the Pledge "requires affirmation of a belief and an attitude of mind., ${ }^{, 30}$

The Court then considered and rejected the idea that the Constitution permitted government compulsion of expression as a means of achieving the government's interest in national unity. ${ }^{31}$ Government under the Constitution was by consent of the governed, but the Bill of Rights denied government the power to coerce that consent, as opposed to achieving it through education and persuasion. ${ }^{32}$

25. See Barnette, 319 U.S. at 629-30.

26. See Minersville Sch. Dist. v. Gobitis, 310 U.S. 586, 591-600 (1940); Gaebler, supra note 7, at $997 \& \mathrm{n} .11$; see also Jacobs, supra note 7, at $131 \mathrm{n} .50$ (suggesting that the Court's change three years later was due to the fact that World War II was almost over and the need for statutes compelling national unity was less urgent than it had been). For analysis of the flag salute cases, see generally 1 THE Constitution and the FlaG: The FlaG SaluTE CASES (Michael Kent Curtis ed., 1993).

27. See Barnette, 319 U.S. at 630; Michael Kent Curtis, Introduction to 1 THE Constitution and THE FLAG: The Flag SALuTE CASES, supra note 26, at xxxii; Stephen W. Gard, The Flag Salute Cases and the First Amendment, 31 CLEV. ST. L. REV. 419, 423 (1982), reprinted in 1 The Constitution AND THE FlaG: The FlaG SALUTE CASES, supra note 26, at 293, 293.

28. See Barnette, 319 U.S. at 631; Curtis, supra note 27, at xxxii ("The issue was not about ends but about means."); Gard, supra note 27, at 293 \& n.30 (arguing that the Court stated the question in the case as whether government could "enforce patriotism by the means of compelling an affirmation of belief").

29. See Barnette, 319 U.S. at 633; see also Curtis, supra note 27, at xxxii-xxxiii; Gaebler, supra note 7, at 998 .

30. See Barnette, 319 U.S. at 633.

31. See Curtis, supra note 27, at xxxiii ("At bottom, the Barnette Court rejected the ideas about compelled national unity that were the heart of Gobitis.").

32. See Barnette, 319 U.S. at 641. 
As for the notion that the failure to compel patriotism and national unity, by permitting intellectual and spiritual contrariness, would lead to the disintegration of society, the Court rejected that as resting on "an unflattering estimate of the appeal of our institutions to free minds.",33 The Court closed with a well-known rhetorical flourish:

If there is any fixed star in our constitutional constellation, it is that no official, high or petty, can prescribe what shall be orthodox in politics, nationalism, religion, or other matters of opinion or force citizens to confess by word or act their faith therein. If there are any circumstances which permit an exception, they do not now occur to us. ${ }^{34}$

Barnette laid the ground for free speech protection from government demands that one "express ... acceptance of or agreement with any particular belief.",

The next opportunity for the Court to address direct government compulsion of a message came thirty years later in Wooley $\mathrm{v}$. Maynard. ${ }^{36}$ Two more Jehovah's Witnesses, husband and wife citizens of New Hampshire, objected to displaying the state motto "Live Free or Die" on their license plates; they covered the motto with tape and were arrested three separate times on the misdemeanor charge of obscuring a portion of the license plate from view. ${ }^{37}$

The Court began with the proposition, drawn from Barnette, that the "right of freedom of thought protected by the First Amendment against state action includes both the right to speak freely and the right to refrain from speaking at all," both complementary components of the broader concept of "individual freedom of mind."38 The Court recognized that requiring a person to utter the Pledge created a more serious infringement on personal liberties than the passive act of displaying the state motto on the license plate, but found this to be a difference only in degree. ${ }^{39}$ Instead, Barnette and Wooley both involved state measures that forced an individual to serve as "an

33. See id.

34. Id. at 642 .

35. See Gaebler, supra note 7, at 998.

36. 430 U.S. 705 (1977); see Gard, supra note 27, at 306 (stating that Barnette went unused for years until rediscovered as a major freedom of expression precedent); see also Gaebler, supra note 7, at 998 (suggesting that, prior to Wooley, direct application of a free speech rationale was unnecessary because similar cases either were resolved on grounds of free exercise of religion or on the ground that refusal to salute the flag was an affirmative symbolic expressive act, presented through silence).

37. See Wooley, 430 U.S. at 707-08; Gaebler, supra note 7, at 999.

38. Wooley, 430 U.S. at 714; see also Cantor, supra note 11, at 11; Gaebler, supra note 7 , at 999 .

39. See Wooley, 430 U.S. at 715; Gaebler, supra note 7, at 999. 
instrument for fostering public adherence to an ideological point of view he finds unacceptable., ${ }^{, 40}$ Fundamental free speech interests were implicated by a state attempt to require an unwilling individual to use her private property as a "mobile billboard" for the government's ideological message on threat of criminal penalty.

The Court considered and rejected the state's asserted interest in requiring display of the motto as a way to promote appreciation of history, individualism, and state pride; no matter how legitimate the interest in communicating government ideology, it did not and could not outweigh the individual's First Amendment right to avoid becoming the courier of that message. ${ }^{42}$ New Hampshire's interest in promoting appreciation of its history was no different, and no more sufficient, than West Virginia's interest in promoting patriotism and national unity; Wooley and Barnette thus were "not merely analogous, but doctrinal twins.",33

The most recent example of compelled direct presentation of a message was Hurley v. Irish-American Gay, Lesbian, and Bisexual Group, Inc. ${ }^{44}$ The Massachusetts public accommodations law had been applied to require the private organizers of South Boston's St. Patrick's Day Parade to allow the Gay, Lesbian, and Bisexual Group of Boston (GLIB) to march in the parade under its own banner. ${ }^{45}$ The Court found that a parade is a form of expression, composed of its banners and songs and marked by its overall symbolism. ${ }^{46}$ Moreover, the parade need not have a single, narrow, succinctly articulable message

40. See Wooley, 430 U.S. at 715; Gaebler, supra note 7, at 999-1000; Gard, supra note 27 , at 306 .

41. See Wooley, 430 U.S. at 715; see also Gard, supra note 27 , at $318-19$ ("It is simply contrary to the democratic premise of the first amendment to allow the government to compel the unconsenting to use their person or privately owned property as a "mobile billboard' for the State's ideological message." (internal quotation omitted)).

42. See Wooley, 430 U.S. at 716-17; Jacobs, supra note 7, at 132.

43. Gard, supra note 27, at 318.

44. 515 U.S. 557 (1995). Hurley could be analyzed as a compelled-access case, in which the state law at issue required a private forum owner to provide access to another private speaker. See Jacobs, supra note 7, at 135-36 (discussing Hurley as compelled access case); Martin H. Redish \& Kirk J. Kaludis, The Right of Expressive Access in First Amendment Theory: Redistributive Values and the Democratic Dilemma, 93 Nw. U. L. REv. 1083, 1126 (1999) (same). Because the Hurley Court focused on the parade organizers as particularized speakers presenting a chosen message, it properly may be viewed in this category of compelled-expression cases.

45. See Hurley, 515 U.S. at 560-63; Jacobs, supra note 7, at 135-36.

46. See Hurley, 515 U.S. at 568-69 ("[W]e use the word 'parade' to indicate marchers who are making some sort of collective point, not just to each other but to bystanders along the way."). 
in order to avail itself of First Amendment protection. ${ }^{47}$ It followed that the parade organizer was a distinct private speaker, with the right to assemble its own message by combining nonoriginal, multifarious voices. The selection of those contingents to form the overall parade message was entitled to protection. ${ }^{48}$ Every participating unit affected the content of that message, meaning the forced inclusion of a particular unit inevitably and impermissibly altered the expressive content of the parade and of the parade organizer's message. ${ }^{49}$

Hurley is distinct from Barnette and Wooley in that the compelled message to be presented (GLIB's banner and the group's message of being Irish, gay, and proud) ${ }^{50}$ is not that of government, but of another private speaker. But this does not change the analysis, because in both situations government compels a private speaker to present some message not its own. ${ }^{51}$ The Hurley Court recognized Barnette as establishing a general prohibition on government compulsion of affirmance of beliefs, values, opinions, and facts with which an individual disagrees; ${ }^{52}$ this applied regardless of the source (governmental or private) of the beliefs, values, opinions, and facts compelled. The parade organizer's claim to the benefit of this general principle was "as sound as the South Boston parade is expressive." ${ }^{33}$

The parade organizers had decided to exclude a message they did not like from their parade message, and that was sufficient to invoke their rights as private speakers to shape expression, by speaking on one subject and remaining silent on another. ${ }^{54}$ The right to autonomy over the content of the message would be compromised by any

47. See id. at 569-70.

48. See id. ("Rather like a composer, the [parade organizer] selects the expressive units of the parade from potential participants, and though the score may not produce a particularized message, each contingent's expression in the [organizer's] eyes comports with what merits celebration on that day.").

49. See id. at 570 (stating that the selection of contingents to make a parade is entitled to protection); Jacobs, supra note 7, at 136.

50. The Hurley Court noted:

GLIB was formed for the very purpose of marching in [the parade] . . . in order to celebrate its members' identity as openly gay, lesbian, and bisexual descendents of the Irish immigrants, to show that there are such individuals in the community, and to support the men and women who sought to march in the New York parade.

Hurley, 515 U.S. at 570.

51. Moreover, we may assume that the government agrees with or supports the compelled private message, or at least that the government wants the message to be presented to the public, through the public accommodations law that protects gays and lesbians.

52. See Hurley, 515 U.S. at 573-74.

53. See id. at 574.

54. See id. 
government-imposed requirement that a speaker disseminate a view contrary to its own. ${ }^{5 s}$

\section{Compelled Subsidization of Private Expression}

While Barnette, Wooley, and Hurley reflect the early paradigm of compelled speech - a speaker forced to utter a government-prescribed or government-favored message-modern examples of compelled expression tend to be less obvious, less dramatic, and more complex. ${ }^{56}$ The second category involves government-compelled funding or financial support of political and ideological expression by private speakers and organizations.

Abood v. Detroit Board of Education marked the first time a Court majority ${ }^{57}$ held that the First Amendment rights of objecting nonunion employees were violated by a labor union's use of mandatory member dues payments for political and ideological speech, where nonunion employees were required to pay dues to the union pursuant to an agency-shop agreement established in accordance with state law. ${ }^{58}$ The required payment of such dues was designed (1) to promote labor peace by establishing a single authorized bargaining unit empowered to enter into a single agreement with management and (2) to distribute the costs of union activities among all those workers who benefit, avoiding a free-rider problem. ${ }^{59}$

The Court recognized that compelling employees to support the union financially impacted employees' First Amendment interests. ${ }^{60}$ But in the context of collective bargaining, contract administration, grievance adjustments, and other core union activities, such compelled payments were permissible, justified by those state interests. ${ }^{61}$ As long

55. See id. at 576; Jacobs, supra note 7, at 136.

56. See Kamenshine, supra note 23, at 102.

57. See Cantor, supra note 11, at 8-10 (discussing earlier cases of this type that drew only a plurality or that were decided on statutory rather than constitutional grounds); see also Int'l Ass'n of Machinists v. Street, 367 U.S. 740, 750 (1961) (plurality opinion) (construing statute to prohibit use of objectors' dues to finance political campaigns and to promote political doctrines); Ry. Employees Dep't v. Hanson, 351 U.S. 225, 238 (1956) (same).

58. Abood v. Detroit Bd. of Educ., 431 U.S. 209, 211-12 (1977); Gaebler, supra note 7, at 1000; Jacobs, supra note 7, at 136-37; see also Cantor, supra note 11, at 12 (stating that Abood made a "quantum leap by connecting forced fees payments to a service institution with impermissible, compelled ideological association").

59. See Abood, 431 U.S. at 224; see also Cantor, supra note 11, at 12; Gaebler, supra note 7 , at 1000 .

60. See Abood, 431 U.S. at 222.

61. See id. at 225 ("[I]mportant government interests ... presumptively support the impingement upon associational freedom created by the agency shop here at issue."); see also 
as the union used the fees to promote those causes for which it was formed and for which it brought members together, an individual payer could not withdraw financial support merely because she disagreed with the group's contract strategy. ${ }^{62}$ This was true even if all the union's activities could be regarded, in some sense, as political. ${ }^{63}$

However, the Court drew a "constitutional line." Employees could not be required to contribute funds to those ideological and political causes that the individual payer may oppose. ${ }^{65}$ The union could spend money to support political candidates or political causes or to engage in activities that, in the Court's view, were not "germane" to the union's duties as a collective bargaining representative. ${ }^{66}$ But the union could use only funds collected from those employees who were not required to pay and who did not object to advancing these ideas. ${ }^{67}$ The Court suggested that the remedy would be restitution to the objecting employee of a fraction of her union dues, equal to the fraction of total union expenditures that were made for the impermissible objectionable political purposes. ${ }^{68}$

In Keller v. State Bar of California, the Court extended Abood to an integrated state bar, to which all attorneys must belong and pay dues as a condition of practicing law in the state. ${ }^{69}$ The Court held that the bar could fund from the mandatory dues of its members only those activities "germane" to the bar's goals of regulating the legal profession and improving the quality of legal services, but not expression of an ideological nature that falls outside the scope of those activities. $^{70}$ The Court attempted to define the latter category, setting the standard as "whether the challenged expenditures are necessarily or reasonably incurred for the purpose of regulating the legal profession or improving the quality of the legal service available to the people of the State." $" 11$ The Court declined to illustrate these categories, although it outlined the extreme ends: government could not expend compulsory dues to endorse or advance a gun control or nuclear

Cantor, supra note 11, at 12-13 (stating that the Court found the impairment of ideological interests justified insofar as the fees were used for contract-related expenses).

62. See Abood, 431 U.S. at 223.

63. See Cantor, supra note 11, at 13.

64. See id.

65. See Abood, 431 U.S. at 235-36.

66. See id.

67. See id. at 235-36; Jacobs, supra note 7, at 136-37.

68. See Abood, 431 U.S. at 238.

69. 496 U.S. 1, 4-5 (1990).

70. See id. at 13-14.

71. Id. at 14 (internal quotations omitted). 
weapons freeze initiative, but it could use those dues for activities connected with disciplining members of the bar or proposing ethical codes for the profession. ${ }^{72}$

In Lehnert v. Ferris Faculty Ass'n, the Court returned to public employee, agency-shop agreements, establishing a three-part test for determining which side of the Abood/Keller line a union expenditure fell. ${ }^{73}$ Chargeable activities (those that may be funded with the dues of all payers) must: '(1) be 'germane' to collective-bargaining activity; (2) be justified by the government's vital policy interest in labor peace and avoiding 'free riders'; and (3) not significantly add to the burdening of free speech that is inherent in the allowance of an agency or union shop." "74 Among "germane" activities were threatening and preparing for a strike (even a strike that would have been illegal) and paying for the chargeable activities of state and national affiliates of the local union that ultimately may inure to the benefit of the local by virtue of membership. ${ }^{75}$ Nonchargeable activities (those that could be financed only with the dues of agreeing, noncompelled payers) included lobbying and other political activities outside the limited context of contract ratification or implementation, as well as establishing a program designed to secure funds for public education in the state. ${ }^{76}$

Arguments have been made for extending Abood-type protections to a superficially similar situation: corporate expressive expenditures using invested moneys of shareholders who object to the corporation's message. These arguments justify restrictions on corporate speech pursuant to a compelling government interest in protecting the free speech interests and values of dissenting shareholders." The idea is that restrictions on corporate political and

72. See id. at 15-16; see also id. at 5 (describing the bar's nonexpressive, germane activities, which included "examining applicants for admission, formulating rules of professional conduct, disciplining members for misconduct, preventing unlawful practice of the law, and engaging in study and recommendation of changes in procedural law and improvement of the administration of justice" (internal quotations omitted)); $i d$. at 5-6 \& n.2 (listing some of the challenged activities, including lobbying against legislation criminalizing the display of drug paraphernalia or creating exclusions from the gift tax and lobbying for state legislation prohibiting possession of armor-piercing handgun ammunition and for creating an unlimited right of action to sue anybody causing air pollution).

73. 500 U.S. $507(1991)$.

74. Id. at 519 .

75. Id. at 524, 531-32.

76. See id. at 522,$527 ; i d$, at 559 (Scalia, J., concurring in the judgment in part and dissenting in part).

77. See Martin H. Redish \& Howard M. Wasserman, What's Good for General Motors: Corporate Speech and the Theory of Free Expression, 66 GEO. WASH. L. REv. 235, 
ideological expenditures are justified by the "need to protect individual stockholders against being forced to choose between contributing to political or social expressions with which they disagree or foregoing opportunities for profitable investment.",78 The lesson of Abood and Keller is that "financial supporters of an association do not give up their own First Amendment rights of freedom of association and speech simply because they supply money to the group" and this lesson protects corporate investors and shareholders. ${ }^{79}$ Commentators have defended requirements that corporations use segregated funds, under which the corporation engages in political and ideological expression only with funds collected separately from explicitly consenting shareholders, as an alternative to an Abood-type pro rata refund. $^{80}$

The compelled-shareholder argument has never attained a majority of the Court; in Bellotti, the majority expressly rejected the position. ${ }^{81}$ The refusal to extend the protections of Abood and Keller to corporations and corporate shareholders is proper. Most importantly, the state does not compel shareholders to invest at all or to invest in any particular company; this contrasts with unions, in which state laws permitting agency-shop agreements may require individuals at least to pay money to the union (even if they do not join as full members) as a condition of holding a job, engaging in an occupation,

271 (1998) (describing the arguments); see also Austin v. Mich. Chamber of Commerce, 494 U.S. 652, 673 (1990) (Brennan, J., concurring) (arguing that requiring a corporation to fund political speech only from a segregated fund of moneys collected from consenting shareholders was justified by the state's interest in protecting shareholders from funding objectionable political speech); id. at 675 (arguing that the state "surely has a compelling interest in preventing a corporation it has chartered from exploiting those who do not wish to contribute" to political expression); First Nat'l Bank of Boston v. Bellotti, 435 U.S. 765, 812 (1978) (White, J., dissenting) (arguing that the state could take steps to protect individual shareholders and to ensure that they are not compelled to support and financially further ideas, beliefs, and positions with which they disagree, at least where the speech did not materially affect the business or property interests of the corporation).

78. Victor Brudney, Business Corporations and Stockholders' Rights Under the First Amendment, 91 YALE L.J. 235, 268 (1981); see id. at 270 (arguing that the First Amendment interests of objecting investors are similar to those of objecting union-dues payers and offer comparable support to restrictions on speech by the private entity); Adam Winkler, Beyond Bellotti, 32 LOY. L.A. L. REV. 133, 200 (1998) ("To the extent the corporation uses a shareholder's money to support political causes he disagrees with, the shareholder may end up feeling abused and powerless.").

79. See Winkler, supra note 78 , at 210.

80. See Brudney, supra note 78, at 272. But see Redish \& Wasserman, supra note 77, at 279 (arguing that the speech of a corporation's segregated fund is not that of the corporation, but of some subset of its shareholders).

81. See Bellotti, 435 U.S. at $794-95$ \& n.34. 
and earning a living. ${ }^{82}$ Absent that government compulsion, there can be no First Amendment violation arising from payments to private organizations, even if those payments are used for expressive purposes. $^{83}$ Where corporate investors are concerned, no state law compels them to invest their money in a particular company; the choice is voluntary, or at least free of government compulsion. ${ }^{84}$

Perhaps one could compare an individual worker's decision to enter a particular occupation in a particular location (such as practicing law in California) to the decision to invest in a company, both of which are equally voluntary. ${ }^{85}$ But that is the wrong analogy, focused on the wrong step. The decision to enter the legal profession is properly analogous to the equally voluntary individual decision to invest money in some manner or form in the first instance, without regard to where.

The compelled-speech inquiry must focus on the presence or absence of government compulsion in the choice to pay money to the relevant private organization (union, bar association, or corporation)in other words, the choice to pay money to the speaker. State law commanded the objecting attorneys in Keller to join the state bar. ${ }^{86}$ But the law does not compel anyone to invest in, or give money to, any particular corporation; investment in the company must be understood as voluntary. If state law compelled individual investment in (or subsidization of), for example, Microsoft and its expression, the analysis arguably would change.

82. See Austin, 494 U.S. at 710 (Kennedy, J., dissenting) ("One need not become a member of the Michigan Chamber of Commerce or the Sierra Club in order to earn a living."); Bellotti, 435 U.S. at 795 n.34 (arguing that no shareholder has been compelled to do anything, that the decision to invest in a corporation is made of the shareholder's own volition); see also Redish \& Wasserman, supra note 77, at 275 ("The difference between labor unions and corporations, then, amounts to the difference between state-compelled membership as a prerequisite to earning a living and voluntary investment.").

83. See United States v. United Foods, Inc., 533 U.S. 405, 413 (2001) ("'A] threshold inquiry must be whether there is some state imposed obligation which makes group membership less than voluntary ...."); Cantor, supra note 11, at 19 ("A first amendment violation would not seem to arise without government prescription of a message or forced identification with, or affirmation of, a message by the payor.").

84. This disposes of the argument that, for example, a member of a pension fund has no knowledge of or real control over where her money will be invested. See Winkler, supra note 78 , at 210 . Accepting that as true, the decision as to where the money goes still is not made by the government and does not raise free speech concerns. To the extent a pensioner's investment in a particular company is compelled, it is compelled by the private operators of the pension fund, not by the government.

85. See Winkler, supra note 78, at 210 ("In none of these scenarios does the state force anyone to join. It is up to the individual to make the free choice whether to go to work at a union shop, practice law as a profession, ... or invest in a corporation.").

86. See Keller v. State Bar of Cal., 496 U.S. 1, 5-6 (1990). 
The Bellotti majority correctly noted that the more relevant and appropriate analogy is between a voluntary corporate shareholder and an employee who joins the union but later comes to disagree with its position on some issue. ${ }^{87}$ Both scenarios entail voluntary membership and subsequent disagreement with some aspect of the organization's message. Objecting payer cases involve an objector who has been made a less-than-voluntary member of the speaking organization. ${ }^{88}$

\section{Compelled Subsidization of Expression Pursuant to Government Programs}

A third category of compelled expression, closely related to the second, involves compelled payments for what might be called semiprivate speech pursuant to a government program. In these cases, a government program establishes a private speaking entity to which individuals in a particular industry must pay money, which money is used by the entity, wholly or in part, for expressive purposes.

In Glickman v. Wileman Bros. \& Elliott, federal law limited competition in the tree-fruit industries in favor of collective industry action, including providing the industry with an antitrust exemption. ${ }^{89}$ The law gave the Secretary of Agriculture the power to issue marketing orders - a species of economic regulation - covering a range of industry activities, implemented by a committee comprised of industry members. ${ }^{90}$ All industry participants paid mandatory assessments to cover expenses, administration, research, and other collective activities. ${ }^{91}$ Among the activities covered (and paid for with the collected assessments) was generic product advertising, designed to serve common industry interests in promoting the sale of tree fruits. The message of the advertisements was that California tree fruits generally (without regard to producer) were "wholesome, delicious, and attractive to discerning shoppers.",92

The Court rejected a First Amendment challenge to the generic advertising program brought by several objecting industry members, emphasizing the unique statutory context at issue, in which a broader collective enterprise constrained individual freedom of action and in

87. See Bellotti, 435 U.S. at 795 n.34.

88. See Lehnert v. Ferris Faculty Ass'n, 500 U.S. 507, 513 (1991) (noting that plaintiffs were members of the faculty, required to pay fees to the union); Keller, 496 U.S. at 6 (noting that plaintiffs were members of the bar, as required by state law).

89. 521 U.S. 457,461 (1997).

90. See id. at 461-62.

91. See id. at 462 .

92. See id. 
which the funding of generic advertising was part of that broader enterprise. $^{93}$ The Court removed the case from the compelledexpression mold, because the marketing program did not compel producers to endorse or to finance any political or ideological views. ${ }^{94}$ Abood "did not announce a broad First Amendment right not to be compelled to provide financial support for any organization that conducts expressive activities," but only a right of "not being compelled to contribute to an organization whose expressive activities conflict with one's 'freedom of belief.", 95 In any event, the Court found that the test as stated in Keller had been met, in part because the assessments were not used to fund ideological activities. ${ }^{96}$ Moreover, the advertising at issue did not form any particular message, "other than encouraging consumers to purchase California tree fruit." extent that was a specific message, the Court assumed that the complaining producers would agree with this general idea. ${ }^{98}$

Taken seriously, Wileman Bros. eliminates the Abood/Keller category of compelled-expression protection. Defined broadly, a union and its dues payers agree with the basic organizational goal of protecting the economic and other interests of the workers, just as a corporation and all its corporate shareholders hold in common the basic goal of maximizing profits and the value of individual shares. Disagreement exists, if at all, only as to the wisest expressive or nonexpressive strategies for achieving that goal. ${ }^{99}$ Under Wileman Bros., the individual payer's First Amendment rights do not extend to a desire to pursue that agreed-upon common goal via a different expressive strategy. ${ }^{100}$ Because any speech funded by any organization presumably will serve (or at least be intended to serve) the ultimate shared purpose, one could assume that any organizational speech in fact reflects the shared goal, be it enhancing worker rights or maximizing corporate profits. ${ }^{101}$ Under this reasoning, a compelled dues payer should have no right to opt out of funding any expressive

93. See id. at 469,475 .

94. See id. at 469 \& n. 14; Jacobs, supra note 7, at 137-38.

95. Wileman Bros., 521 U.S. at 471; Jacobs, supra note 7, at 137 .

96. See Wileman Bros., 521 U.S. at 473; see also Jacobs, supra note 7, at 151 (suggesting that Wileman Bros. eliminated free speech review of governmental action where nonpolitical speech is involved).

97. Wileman Bros., 521 U.S. at 472.

98. See id. at 471 ("[N]one of the generic advertising conveys any message with which respondents disagree.").

99. See Redish \& Wasserman, supra note 77, at 278.

100. See Wileman Bros., 521 U.S. at 472, 474-75.

101. See Redish \& Wasserman, supra note 77, at 278. 
activities, as long as those activities serve, or are intended to serve, that common organizational goal. ${ }^{102}$

In addition, the Court seemed to adopt an all-or-nothing approach, analyzing all expenditures together and considering the predominant purpose of the regulatory program as a whole in determining that First Amendment scrutiny should not apply to any uses of compelled payments. ${ }^{103}$ The Court did not separate expressive and nonexpressive expenditures and apply First Amendment scrutiny and germaneness analysis to the former, as it had in previous cases. In Keller, for example, the state bar's primary purpose was nonexpressive, as were the majority of its activities. ${ }^{104}$ Had the Wileman Bros. approach been applied in Keller, there would have been no need to examine separately the other, expressive expenditures; the predominance of nonideological activities would have been enough to defeat the objectors' claims.

However, in United States v. United Foods, Inc., the Court struck down a similar federal mandatory assessment program, this time in the mushroom industry, where most of the funds collected by the statutorily established Mushroom Council were spent on generic advertising promoting collective sales for the entire industry. ${ }^{105}$ The Court took a broader view of compelled expression, finding that First Amendment interests attached because the producers were required by the government program to subsidize speech with which they disagreed. The fact that the disagreement with the generic message was minor-the objecting producer wanted to convey the message that its mushrooms were better than others-did not alter the fact of that disagreement. ${ }^{106}$ Nor did the Court again confine Abood and Keller to political or ideological speech, backing away from the suggestion that compelled funding of speech on any other subject matter is not subject to First Amendment scrutiny. ${ }^{107}$

The Court distinguished Wileman Bros., where the compelled assessments for generic advertising had been part of a larger statutory scheme that established a cooperative market and deprived tree-fruit

102. This also disposes of the pension fund argument, because the contributing fund member will agree with the general profit-making purpose of the fund manager's decisions. See supra note 84 and accompanying text.

103. See Wileman Bros., 521 U.S. at $469,474-75$.

104. See Keller v. State Bar of Cal., 496 U.S. 1, 15-16 (1990).

105. 533 U.S. 405, 408-09 (2001).

106. See id. at 411 .

107. See id. at 413 (" $[$ S]peech need not be characterized as political before it receives First Amendment protection.”). 
producers of the ability to compete, not only through speech, but through production and sales. ${ }^{108}$ By contrast, the mushroom program did not regulate how mushrooms could be produced, sold, or marketed, did not provide an antitrust exemption, and did not create a cooperative, noncompetitive marketplace. ${ }^{109}$ The only collective action required of mushroom growers was that they pay money to the Mushroom Council to generate the very speech to which some of the growers objected. ${ }^{110}$

The Court also found that generic advertising was not germane to any primarily nonexpressive organization independent of speech, as in Abood, Keller, or Wileman Bros., because there was no overarching nonexpressive program beyond advertising. It was not enough that the speech paid for with compelled funds be germane to itself. ${ }^{11}$ Justice Stevens, who authored the majority opinion in Wileman Bros., joined the majority in United Foods, and, in a short concurring opinion, emphasized the absence of that broader regulatory scheme and the presence of only a naked compulsion to support speech, which is no different than a naked restriction on speech. ${ }^{12}$

\section{Compelled Subsidization of Government's Expressive and Nonexpressive Activities}

The fourth category of compelled funding involves mandatory payments to the government. Governments at all levels collect the greatest amount of mandatory and compelled payments from individuals, through receipt of taxes, assessments, fees, fines, and other contributions to the public fisc. ${ }^{113}$ We can break compelled payments to government into two subcategories, as government uses collected payments for both nonexpressive and expressive purposes. ${ }^{114}$

\section{a. Nonexpressive Government Activities}

It is agreed that no taxpayer may object to the use of her payments for nonexpressive policy activities-war efforts, promotion

108. See id. at 414-15.

109. See id. at 412-13.

110. See id. at 415 .

111. See id.

112. See id. at 417-18 (Stevens, J., concurring).

113. Cantor, supra note 11, at 3 (stating that the taxpayer is the most obvious example of a person having money extracted from her to promote various objects).

114. See Andrew Koppelman, Secular Purpose, 88 VA. L. Rev. 87, 111 (2002) (arguing that government expresses an opinion and point of view through the passage of legislation). 
of reproductive choices, provision of welfare or health insurance benefits to the poor, provision of subsidies to corporations - even if those policies offend her moral, political, or ideological sensibilities. ${ }^{115}$ The First Amendment protects freedom of thought and conscience as a concomitant of the freedom to speak (and not to speak). ${ }^{116}$ The protection of conscience does not extend to objections to supporting nonexpressive governmental actions that, presumably, represent the will of the majority that placed the acting officials in office. ${ }^{117}$ Rather, some incursion on conscience from nonexpressive government activities is "an inevitable concomitant of living in an organized society." 118 The First Amendment does not and cannot elevate "pure peace of mind" to the highest constitutional status in an organized society; the result would be administrative gridlock, as government attempts the impossible task of funding public programs and policies only with taxes or payments collected from those members of the polity who support a particular program or policy. ${ }^{119}$ The result would be a prohibitive restriction on representative government's ability to act at all.

Instead, one must accept that she will lose some electoral and legislative battles, and that the result of losing in a democratic process will be having to live under, and pay taxes and other fees for, some

115. See Cantor, supra note 11, at 3 (arguing that pacifists' taxes fund war efforts and antiabortion activists' taxes further birth control and abortion); see also Bd. of Regents of the Univ. of Wis. Sys. v. Southworth, 529 U.S. 217, 229 (2000) ("The government, as a general rule, may support valid programs and policies by taxes or other exactions binding on protesting parties."); Jed Rubenfeld, The New Unwritten Constitution, 51 DUKE L.J. 289, 297 (2001) ("A person gets no special immunity from the tax code just because he objects to the federal government and wants to communicate this view by not paying.").

116. See Wooley v. Maynard, 430 U.S. 705, 714 (1977) ("The right to speak and the right to refrain from speaking are complementary components of the broader concept of 'individual freedom of mind.'"); Alexander Meiklejohn, The First Amendment Is an Absolute, 1961 SUP. CT. REv. 245, 257 (arguing that a citizen "may not be told what he shall or shall not believe"); see also Ashcroft v. Free Speech Coalition, 122 S. Ct. 1389, 1403 (2002) ("The right to think is the beginning of freedom, and speech must be protected from the government because speech is the beginning of thought.").

117. See Cantor, supra note 11, at 21 ("It is a truism that a minority of citizens ... may be bound by collective judgments which are ideologically repugnant.").

118. Cantor, supra note 11, at 25; see also Southworth, 529 U.S. at 229 ("It is inevitable that government will adopt and pursue programs and policies within its constitutional powers but which nevertheless are contrary to the profound beliefs and sincere convictions of some of its citizens.").

119. See Cantor, supra note 11, at 26 (arguing that, because the range of conscientious objections to public policy is limitless, pure peace of mind cannot be elevated in an organized society without serious administrative entanglements); Greene, supra note 17, at 17 ("[T]he justification for any particular use of tax dollars should not have to overcome these stricter hurdles of legitimacy, but rather merely those of policy."). 
unwanted laws and policies. ${ }^{120}$ Government is indeed by the consent of the governed, and that consent must be voluntarily given. ${ }^{121}$ But having consented to the formation of government and to being part of a majoritarian community, a citizen cannot, via her First Amendment right of conscience, control the way government spends money from its treasury in furtherance of the majority's policy goals. So long as any laws do not infringe some constitutional right, the individual must comply with (and pay for) them, at least until the next electoral measurement of a majority in some political constituency that might bring about a change in public policy. ${ }^{122}$ The First Amendment demands only that the objector maintain her right to dissent from objectionable policies by speaking against the policies and the elected officials who pass and enforce them. ${ }^{123}$

\section{b. Expressive Government Activities}

Government necessarily possesses broad discretion to select and put forward its own message as a way of presenting, explaining, and defending its policies to the People. ${ }^{124}$ Such participation by government in public debate not only is legitimate, but absolutely necessary in a democratic political system. ${ }^{125}$

120. See Greene, supra note 17 , at 18 .

121. See W. Va. State Bd. of Educ. v. Barnette, 319 U.S. 624, 641 (1943); cf. THE DECLARATION OF INDEPENDENCE para. 1 (U.S. 1776) ("Governments are instituted among Men, deriving their just Powers from the Consent of the Governed ....").

122. Cf. Steven G. Calabresi \& Joan L. Larsen, One Person, One Office: Separation of Powers or Separation of Personnel?, 79 CORNELL L. REv. 1045, 1093 (1994) (describing "complex and highly sophisticated" multitiered method for sampling the will of the people, in which different constituencies of the people make majority determinations at set intervals).

123. See Greene, supra note 17, at 17-18 (emphasizing that dissent must be left open and that the government's conception of the good should be only one of many advanced); see also Steven H. Shiffrin, Dissent, InJustice, AND the MEANings of America 10 (1999) (arguing that dissenters, those who challenge existing customs and authorities, are central to the First Amendment); Akhil Reed Amar, Comment, The Case of the Missing Amendments: R.A.V. v. City of St. Paul, 106 HARV. L. REv. 124, 152-53 (1992) (arguing that the Fourteenth Amendment shifted the center of gravity of free speech, towards protection of speech opposed to, and critical of, popularly accepted governmental policies and prevailing social norms).

124. See Legal Servs. Corp. v. Velazquez, 531 U.S. 533, 541 (2001) (emphasizing the latitude that exists where the government's own message is being delivered); Southworth, 529 U.S. at 229 ("[I]t seems inevitable that funds raised by the government will be spent for speech and other expression to advocate and defend its own policies."); Rosenberger v. Rector \& Visitors of Univ. of Va., 515 U.S. 819, 833 (1995) ("When the government disburses public funds to private entities to convey a governmental message, it may take legitimate and appropriate steps to ensure that its message is neither garbled nor distorted by the grantee.").

125. See EMERSON, supra note 17, at 698 ("Participation by the government in the system of freedom of expression is an essential feature of any democratic society."); MARK G. 
In order to represent the People, democratic government-and the elected and appointed public officials through whom democratic government speaks-must be able to speak to the People, to inform, explain, justify, educate, defend, and persuade as to the wisdom and goodness of its policy initiatives and decisions. ${ }^{126}$ Government speech enhances public debate by providing an additional voice and viewpoint in the marketplace, one that enables the People to evaluate government policy and to decide whether to support or oppose that policy, one that

Yudof, When Government Speaks: Politics, LaW, and Government Expression IN AMERICA 41 (1983) ("It is absurd, then, in the modern contexts, to adopt the position that government speech ... is an illegitimate enterprise in a liberal democratic state."); Randall P. Bezanson, The Government Speech Forum: Forbes and Finley and Government Speech Selection Judgments, 83 IowA L. REV. 953, 980 (1998) ("For democracy to function, government and government officials must be able to explain themselves and gather support for collective government action, whether in the form of legislation, adjudication, policy formulation, or the conduct of war."); Bezanson \& Buss, supra note 11, at 1380 ("Government speech, then, must be understood as essential in a republican democracy, and as a necessary inference from the constitutional structure of American government."); Cantor, supra note 11, at 30 (arguing that there are "innumerable ways in which government legitimately speaks"); David Cole, Beyond Unconstitutional Conditions: Charting Spheres of Neutrality in Government-Funded Speech, 67 N.Y.U. L. REv. 675, 703 (1992) ("Government must voice its views in order for the system of self-government to operate ...."); Gard, supra note 27 , at 315 ("[I]t must be recognized that the government does have a legitimate interest in participating in public debate."); Gey, supra note 12, at 1602 (“[C]reating public policy, informing the public about the policy's content, and defending the policy against political opponents is the central purpose of a democratic government."); Greene, supra note 17, at 1718 ("[T]he government may advance particular conceptions of the good and encourage people to follow such conceptions .... .); Martin H. Redish \& Daryl I. Kessler, Government Subsidies and Free Expression, 80 MINN. L. REV. 543, 560 (1996) ("A democratic society must permit the government on occasion to communicate with the populace, both with its own voice and through the voices of others.").

126. See EMERSON, supra note 17, at 698 (arguing that government's ability to speak enables it to "inform, explain, and persuade-measures especially crucial in a society that attempts to govern itself with a minimum use of force" and "provides the facts, ideas, and expertise not available from other sources"); YUDOF, supra note 125, at 41 (arguing that eliminating government speech would deprive government of a primary means of protecting and enhancing democratic values, of enforcing its public policies, and of improving its leadership capacity); Bezanson \& Buss, supra note 11, at 1380 ("Government must explain, persuade, coerce, deplore, congratulate, implore, teach, inspire, and defend with words."); Cantor, supra note 11, at 30 ("Government has legitimate functions in informing, educating, persuading, and leading the public."); $i d$. at 31 ("[I]t is a legitimate government function to 'lead' and thus to promote certain ideological perspectives."); Cole, supra note 125, at 703 ("[G]overnment needs to be able to carry out and rally support for its programs by explaining their benefits."); Greene, supra note 17, at 8 ("[G]overnment communication can assist the execution of law through explaining and supporting the laws that are enacted."); Redish \& Kessler, supra note 125, at 565 ("From the perspective of democratic theory, it is essential that these government employees inform the populace of the government's policies and initiatives."); David A. Strauss, Persuasion, Autonomy, and Freedom of Expression, 91 COLUM. L. REV. 334, 364 (1991) ("If private speakers attempt to manipulate people by omitting information or counter-arguments, the government can supply what is missing."). 
the People take into account in making political decisions such as whether to vote for the same public officials in the next election. ${ }^{127}$ Indeed, the Court has stated that it would be "ironic if those charged with making governmental decisions were not free to speak for themselves in the process." ${ }^{128}$ Ultimately, the ability of democratic government to speak for itself is central to its survival. ${ }^{12}$

Government's unrestricted power to speak in its own voice with taxpayer funds rests on the same majoritarian principles as its power to act in nonexpressive ways with those funds. Speech "by the government" really refers to the speech of whatever majority political constituency won control at the last election. ${ }^{130}$ A government official presumptively espouses the views of that constituency of the People that she represents, or at least the majority of that constituency that placed her in office. ${ }^{131}$ Any government expression necessarily is in furtherance of that majoritarian political representation, just as any nonexpressive policy actions are in furtherance of that majoritarian representation. Individual citizens, having lost the legislative or electoral battle, must accept the burden of paying taxes and fees

127. See YUDOF, supra note 125, at 43 (arguing that speech from institutions such as government "provide[s] information and other prerequisites for the exercise of the citizen's judgment about political issues and candidates" and may increase the citizen's ability to make informed choices); Cole, supra note 125 , at 703 ("[T]he people need to know their representative's views to decide whether to support them ...."); Abner S. Greene, Government Speech on Unsettled Issues, 69 FoRDHAM L. REV. 1667, 1684 (2001) ("We trust the people to distinguish good arguments from bad ones all the time .... Why can't we trust the very same population to weed out bad governmental arguments from good ones?"); Redish \& Kessler, supra note 125, at 565 (arguing that government speech makes citizens better able to hold government actors accountable by providing more information with which to judge the performance of political leaders).

128. See Keller v. State Bar of Cal., 496 U.S. 1, 12 (1990).

129. See YUDOF, supra note 125, at 41 (arguing that restrictions on speech would strip government of a primary means of "securing its ability to survive"); Bezanson, supra note 125 , at 980 ("Without the capacity to act as a speaker, government could not do many of the things it does and must do."); Bezanson \& Buss, supra note 11, at 1380 (arguing that none of government's tasks could be successfully pursued without speech by government); Cole, supra note 125, at 702 ("[G]overnment functions in large measure through communication and persuasion ...."); Greene, supra note 17, at 8 ("It is hard to imagine government functioning without communicating.").

130. Gey, supra note 12 , at 1602 .

131. See YUDOF, supra note 125 , at 152 ("'[I]n a representative democracy public officials must by definition represent the preferences of the majority in some sense, or at least be responsive to citizen preferences in a procedural setting that is recognized as fair and legitimate."); Cole, supra note 125, at 703 ("We elect representatives because we believe they 'speak for us'; it would be perverse to disempower them from speaking once they become government actors."); see also Keller, 496 U.S. at 12 ("Government officials are expected as a part of the democratic process to represent and to espouse the views of a majority of their constituents."). 
towards majority-favored government speech in support of those majority-favored policy choices. ${ }^{132}$ Again, the individual retains her vital First Amendment right to engage in counterspeech and to seek out competing, contrary voices and messages. ${ }^{133}$ Most importantly, government ultimately is accountable to the electorate and the political process if its speech or policies prove unpopular. ${ }^{134}$

There are two primary objections to government speech. One focuses on its power to skew or dominate the marketplace of ideas and the public debate, as a singular, uniquely powerful voice blessed with greater resources and a greater ability to be heard by, and to influence, the People. ${ }^{135}$ Government speech, it is argued, distorts the thinking processes of listeners by capturing the audience, muffling other voices, and forcing listeners to submit to the government's message. ${ }^{136}$ Government power to teach, inform, and persuade necessarily equals the converse power to indoctrinate, distort judgments, and perpetuate the current political regime. ${ }^{137}$

132. See Greene, supra note 17 , at 18 (arguing that one of the burdens on the individual of losing the majoritarian battle is to listen to and help fund speech that she opposes, such as speech by the government).

133. See id. at 17-18; see also id. at 16 ("As a tax/dues/fees payer, a person remains free to speak all she wants or not at all."); id. at 50 (discussing importance of listener, confronted with government speech, being able to seek and find other views).

134. See Bd. of Regents of the Univ. of Wis. Sys. v. Southworth, 529 U.S. 217, 235 (2000) ("When the government speaks ... it is, in the end, accountable to the electorate and the political process for its advocacy. If the citizenry objects, newly elected officials later could espouse some different or contrary position.").

135. See Cole, supra note 125, at 704 (discussing the potential that the government might dominate or skew public dialogue); Greene, supra note 17, at 49 (suggesting that government speech becomes problematic when it monopolizes the area of debate or closes dissent); Greene, supra note 127, at 1682-83 (agreeing that government speech is a problem if it monopolizes the speech market or coerces citizen choices); Robert D. Kamenshine, The First Amendment's Implied Political Establishment Clause, 67 CAL. L. REV. 1104, 1104 (1979) ("The government has the potential to use its unmatched arsenal of media resources and legislative prerogatives to obtain political ends, to nullify the effectiveness of criticism, and, thus, to undermine the principle of self-government."); id. at 1108 ("[T]he government would obviously still bring all of its prestige and economies of scale to bear on the political debate.").

136. See YUDOF, supra note 125, at 168-69; see also Bezanson \& Buss, supra note 11, at 1511 (arguing that government speech should not "have the purpose or effect of dominating expression on a particular subject or expression of a particular point of view, displacing competing speech or private speech choices by the exercise of monopoly power over a forum, or transforming private speech into an expression of government preference"); Kamenshine, supra note 135, at 1105 ("If a government can manipulate that marketplace, it can ultimately subvert the processes by which the people hold it accountable.").

137. See YUDOF, supra note 125, at 42; Cantor, supra note 11, at 30-31; see also Gey, supra note 12, at 1602 (stating that limitations on the manner in which government may speak ensure that the majority does not abuse its power of speech in order to manipulate the results of the next election). 
The second objection concerns governmental "ventriloquism," in which government presents its message not with its own voice, but through private speakers using government funds. ${ }^{138}$ The problem with ventriloquism is that the recipients of the speech, namely the People, are less likely to recognize the governmental source of the message or to understand the connection between a particular message and the policy issues, making them less able to hold government properly accountable for both. ${ }^{139}$ Voters can recognize some level of self-interest in the government's speech and discount the message by considering the source. ${ }^{140}$ Evaluating and discounting the message becomes more difficult, if not impossible, when government deputizes private persons to foster its views and positions and does not clearly present the message itself, as its own. ${ }^{14}$ So, too, does the ability to hold government accountable for its speech. ${ }^{142}$

The point of Barnette and Wooley is that, regardless of government's unquestioned interest in speaking and spreading its message, it may not conscript unwilling private citizens to assist in the dissemination of that message or convert individuals into a billboard or mouthpiece for that message. ${ }^{143}$ Beyond that, challenges to government speech do not proceed from concerns for the rights of objecting taxpayers not to have their tax dollars or other compelled assessments spent for government speech.

138. See Greene, supra note 17 , at 49 (defining governmental ventriloquism as situations in which speech is not clearly defined as that of the government).

139. See Bezanson \& Buss, supra note 11, at 1510 ("[G]overnment should be able to act as a speaker only when it does so purposefully, with an identified message, which is reasonably understood by those receiving it to be the government's message.").

140. See Greene, supra note 17 , at 49 ("[C]lear identification of speech as the government's enhances accountability ....); Redish \& Kessler, supra note 125, at 565 ("[T]he populace can evaluate the message with an eye toward the messenger.").

141. See Bezanson \& Buss, supra note 11, at 1510 (arguing that requiring government to speak through an openly identified message permits the speech to be judged in terms of the audience's receipt of the message and its understanding that the speech is the government's own); Greene, supra note 17, at 50 (arguing that when the source of the speech is masked, such value assessment "will be muted, not as sharp, the tasks not as clearly defined"); Redish \& Kessler, supra note 125, at 570 ("[W]hen government fosters dissemination of its positions by means of funding private party expression, the danger arises that the public will fail to 'discount' the views expressed."); see also Gey, supra note 12, at 1609 ("[G]overnment retains the authority to speak on public issues-it simply must do so with internal governmental resources, using public agencies and employees acting in their official capacity.").

142. See Greene, supra note 17 , at 50 (describing the "risk that the public will not see clearly enough the connection between law and resulting speech to hold the government properly accountable").

143. See Gard, supra note 27, at 318-19. 
The result of "Abood-writ-large,"144 an Abood-type, objecting taxpayer's right grounded in the First Amendment, would be an unworkable administrative scheme and, ultimately, the loss of all government speech. Government only can express itself or disseminate its message by expending taxes and other collected revenues; constraints on the ability to collect and spend money constrains government's sole means of communicating. ${ }^{145}$ It would be prohibitively costly to demand that government speak only with fees collected from its supporting majority or that it establish a scheme of opt-outs or pro rata refunds for taxpayers. ${ }^{146}$ The objection in Keller and $A b o o d$ - that a single recipient used dues to advance its own causes - is absent in the taxpayer situation, where general taxpayer funds are used for a wide array of government speech purposes. ${ }^{147}$

One limited contrary view recognizing an objecting taxpayer's protection from funding government speech suggests a line between government speech intended to inform about policies on one hand and government speech intended to persuade, endorse, or advocate the merits of those policies on the other; only the latter would trigger the objector's right. ${ }^{148}$ Thus, a government agency could inform the People about the details of a government policy or program, but could not tout its merits or seek to garner popular support for it. ${ }^{149}$

This argument ignores the fact that there always is an implicit endorsement in any government speech about public policy. If the relevant officials do not support and endorse the policy, they will not adopt that policy in the first instance. The fact that a particular proposal, program, or policy is passed and presented to the People necessarily means that the government (i.e., a majority of the relevant public officials representing a majority of the electorate in the most

144. Greene, supra note 17 , at 12-13.

145. See Gard, supra note 27, at 320.

146. See Bezanson \& Buss, supra note 11, at 1427 (arguing that Abood requires a remedial means that is unworkable, because any system requiring optional fees or a way for payers to opt out from paying for speech activities would be disruptive, expensive, and ineffective); Cantor, supra note 11, at 26 (arguing that serious administrative entanglements would inevitably result from a general objecting taxpayer's right); Greene, supra note 17, at 13 ("[W] hile it is possible to issue pro rata refunds of the dues of nonunion members, it would be impossible (i.e., prohibitively costly) to do the same for taxpayer refunds."). The administrative burden becomes even greater when we consider the possibility of shifting supporting majorities on different issues - a taxpayer may support (and be willing to pay for) the government's message on one subject matter, but oppose (and demand a refund of her money for) the government's message on another.

147. See Greene, supra note 17, at 15.

148. See Kamenshine, supra note 135 , at 1128-29.

149. See id. at 1129. 
recent electoral counting of some constituency of the People) thinks the program is a good idea deserving public support. ${ }^{150}$ That will be clear to anyone receiving even a purely informational message. It is impossible to draw a line between information and persuasion.

Moreover, such a line is ill advised. Because ultimate approval of the policy rests with the electorate (through its power to change the policy by changing the government), no government speech should merely inform; it should inform and persuade the individual to form some opinion or view on the government's actions. ${ }^{151}$ Indeed, the governmental source of the message assists in the opinion-forming process by permitting the voter to consider that governmental source in evaluating the message, perhaps leading the individual to oppose a particular policy or program simply because of that governmental source. ${ }^{152}$

\section{B. Theoretical Bases of Compelled Expression}

\section{Individual Liberty}

The protection against compelled expression is grounded primarily in concerns for individual liberty underlying freedom of speech. Under the individual liberty model, free speech is protected because of its vital function in contributing to the speaker's individual self-fulfillment and self-realization and to her development as a human being. ${ }^{153}$ Speech develops human faculties of thought and belief,

150. See Koppelman, supra note 114, at 111 ("Through legislation, the government can, and often does, express a point of view.")

151. See Bezanson \& Buss, supra note 11, at 1380 (arguing that in a representative democracy, 'governments' speech must consist not just of information but also of explanation, persuasion, and justification to a polity tethered to the policies and preferences acted upon by its representatives"); Cole, supra note 125, at 703 ("[G]overnment needs to be able to carry out and rally support for its programs by explaining their benefits.").

152. See Greene, supra note 17, at 50 (arguing that knowing the government source of speech enables the listener more readily to assess its value); Redish \& Kessler, supra note 125, at 565 (arguing that the People can evaluate the message with an eye toward the messenger and can discount a governmental message accordingly).

153. See C. Edwin Baker, Human LiberTy and Freedom of Speech 69 (1989) ("Speech is protected because, without disrespecting the autonomy of other persons, it promotes both the speaker's self-fulfillment and the speaker's ability to participate in change."); EMERSON, supra note 17, at 6 ("[F]reedom of expression is essential as a means of assuring individual self-fulfillment."); MARTIN H. REDISH, FREEDOM OF EXPRESSION: A CRITICAL ANALYSIS 20-21 (1984) (arguing that speech facilitates the individual's ability to control her own destiny and to develop human faculties); RODNEY A. SMOLLA, FreE SPEECH IN AN OPEN SOCIETY 9 (1992) ("[F]reedom to speak without restraint provides the speaker with an inner satisfaction and realization of self-identity essential to individual fulfillment.”). 
central to the development of free and individual personhood. ${ }^{154}$ The prohibition on government-compelled expression or support of private expression protects these interests in personhood and individual liberty by prohibiting government interference with individual thought, conscience, or belief through a requirement that one adopt, present, or support any message or idea that she does not wish to adopt, present, or support. ${ }^{155}$ This is the heart of Barnette and the Constitution's command that government may not declare orthodoxy in matters of opinion and may not compel citizens to adopt that orthodoxy as their own. ${ }^{156}$

Government-compelled expression infringes upon individual personhood in several ways. First, such compulsion interferes with an individual's ability to define the persona she presents to the world, depriving her of the opportunity to control, define, and shape her public identity by choosing what to say or what not to say. ${ }^{157}$ The essence of the injury is the deprivation of the individual's freedom to

154. See BAKER, supra note 153 , at 59 ("[R]espect for individual integrity and autonomy requires the recognition that a person has the right to use speech to develop herself or to influence or interact with others in a manner that corresponds to her values."); EMERSON, supra note 17, at 6 ("[S]uppression of belief, opinion, or other expression is an affront to the dignity of man, a negation of man's essential nature."); REDISH, supra note 153, at 21 ("[T] represents a use, and therefore a development, of an individual's uniquely human faculties."); SMOLLA, supra note 153, at 9 (arguing that the right of free speech is "a right defiantly, robustly, and irreverently to speak one's mind just because it is one's mind').

155. See EMERSON, supra note 17, at 30 ("Forcing public expression of a belief is an affront to personal integrity."); Cantor, supra note 11, at 15-16, 21 (arguing that Barnette and its progeny can be explained as protection against forced ideological conformity and against the affront to conscience from having to utter or publicly affirm a distasteful message or support a distasteful cause); Gaebler, supra note 7, at 1004 (arguing that compelled expression "does infringe upon what may be called the individual's interest in selfhood"); Redish \& Kaludis, supra note 44, at 1114 (arguing that the harms wrought by compelled expression disrupt the individual's ability to persuade and interfere with the autonomy of her mental processes); see also Hurley v. Irish-Am. Gay, Lesbian \& Bisexual Group, Inc., 515 U.S. 557, 576 (1995) ("'[W] hen dissemination of a view contrary to one's own is forced upon a speaker intimately connected with the communication advanced, the speaker's right to autonomy over the message is compromised."); Abood v. Detroit Bd. of Educ., 431 U.S. 209, 234-35 (1977) ("For at the heart of the First Amendment is the notion that an individual should be free to believe as he will, and that in a free society one's beliefs should be shaped by his mind and his conscience rather than coerced by the State.").

156. W. Va. State Bd. of Educ. v. Barnette, 319 U.S. 624, 642 (1943) ("If there is any fixed star in our constitutional constellation, it is that no official, high or petty, can prescribe what shall be orthodox in politics, nationalism, religion, or other matters of opinion or force citizens to confess by word or act their faith therein.").

157. See Gaebler, supra note 7, at 1004-05. 
decide how she will present herself to the world, by depriving her of the ability to control the messages she presents. ${ }^{158}$

Second, compelled expression interferes with freedom of conscience, an introspective focus on an individual's self-perception. ${ }^{159}$ The injury arises from the individual's feelings of shame and disgrace resulting from the compulsion to support speech not of her choosing and her inability to defy the state on some matter of principle and to stand up for her personal beliefs. ${ }^{160}$ Professor Redish argues that the injury to self-perception carries with it the further harm of "cognitive dissonance, a psychological process whereby an individual who has been forced to express a view contrary to her own eventually rationalizes her actions by subconsciously adopting the positions she has been forced to express." ${ }^{.161}$ The compulsion indoctrinates the compelled speaker as to the chosen message. ${ }^{162}$ Liberty interests are infringed where the speech uttered, presented, or funded is not the freely chosen expression of the speaker or funder. ${ }^{163}$

Third, being compelled to speak or to support another's speech alters the content and impact of the primary message that the compelled speaker wishes to present. An objecting funder may speak on her own, present her own message, and, perhaps, disclaim and correct any misattribution from the compelled message. ${ }^{164}$ But that does not alleviate the harm to individual liberty interests. First, the responding speech itself is, in some sense, coerced, uttered not

158. Id. at 1005; see Jacobs, supra note 11, at 453 (arguing that compelled speech violates individual autonomy by publicly associating the speaker with the unwanted message); Jacobs, supra note 7, at 156 (discussing the danger that the public will perceive a compelled speaker as affirming some message); Redish \& Kaludis, supra note 44, at 1114 (arguing that being compelled to speak publicly humiliates the speaker, thereby demoralizing him and undermining his resolve to maintain his own positions).

159. See Gaebler, supra note 7, at 1005; see also Wooley v. Maynard, 430 U.S. 705, 714 (1977) ("The right to speak and the right to refrain from speaking are complementary components of the broader concept of 'individual freedom of mind."'); Barnette, 319 U.S. at 642 (holding that compelled flag salute "invades the sphere of intellect and spirit").

160. See Gaebler, supra note 7, at 1005-06.

161. See Redish \& Kaludis, supra note 44, at 1114; see also id. at 1115-16 (describing the use of compelled speech in totalitarian regimes as a tool to establish and maintain public compliance, in part by coercing individuals to adopt propaganda messages as their own).

162. See Jacobs, supra note 11 , at 453 ("[F]orced speech indoctrinates the speaker (...").

163. See BAKER, supra note 153 , at 69 (arguing that speech must be the freely chosen expression of the speaker).

164. See Gaebler, supra note 7 , at 1009 (arguing that government-compelled expression does not restrict the expression of any specific views by individuals); Jacobs, supra note 7, at 155 (arguing that the paraders in Hurley could have disclaimed or answered the objectionable message with their own). 
necessarily as an exercise of the individual's free choice, but as a result of the perceived need to counter the government-compelled message. ${ }^{165}$ Second, the mixed message dilutes the impact of the speaker's own chosen message, confusing the audience as to whether the speaker favors her own message or the message she has been forced to present or fund. ${ }^{166}$

\section{Marketplace of Ideas}

It is somewhat less clear whether the compelled-expression doctrine can be explained with reference to a second rationale for the protection of free speech, the maintenance and enhancement of a marketplace for the free exchange of ideas. Dissenting in Abrams $v$. United States, Justice Holmes first suggested that the Constitution codifies the notion that "the ultimate good desired is better reached by free trade in ideas - that the best test of truth is the power of the thought to get itself accepted in the competition of the market."167 The metaphor of the "marketplace of ideas" has been roundly criticized in scholarly literature. ${ }^{168}$ However, one component of the marketplace of

165. See Cantor, supra note 11, at 28 (discussing argument that a compelled payer is impelled to speak in order to counter the collective voice supported by her funds); Jacobs, supra note 7, at 156 ("The real danger in Hurley was that the compelled speech requirement would provoke exactly the disclaimer or reply which would dispel the misattribution.").

166. See Redish \& Kaludis, supra note 44, at 1115 ("[S]urely there would exist a serious risk that the impact of the speaker's utterance of her own views would be diluted as a result of the publicly degrading experience of having to mouth a position which the speaker finds abhorrent."); see also id. at 1114 (positing hypotheticals in which (1) Martin Luther King was required, prior to his speech at a civil rights rally, to present a governmentally authored defense of the morality of segregation, and (2) antiwar leaders were required to articulate the government's position in support of the war at the start of every rally).

167. 250 U.S. 616, 630 (1919) (Holmes, J., dissenting); see BAKER, supra note 153, at 6 ("According to this classic theory, truth is to be discovered through its competition with falsehood."); EMERSON, supra note 17, at 6-7 ("An individual who seeks knowledge and truth must hear all sides of the question, consider all alternatives, test his judgment by exposing it to opposition, and make full use of different minds."); SMOLLA, supra note 153, at 6 ("The 'marketplace of ideas' is perhaps the most powerful metaphor in the free speech tradition."); Clay Calvert, Where the Right Went Wrong in Southworth: Underestimating the Power of the Marketplace, 53 ME. L. REV. 53, 60-61 (2001) (describing origins of theory); William P. Marshall, In Defense of the Search for Truth as a First Amendment Justification, 30 GA. L. REV. 1, 1 (1995) (suggesting that the marketplace metaphor has been "virtually canonized"); Redish \& Kaludis, supra note 44, at 1083 ("[I]t has not been uncommon for scholars or jurists to analogize the right of free expression to a marketplace in which contrasting ideas compete for acceptance among a consuming public.").

168. See, e.g., BAKER, supra note 153, at 14-15 (rejecting assumptions underlying the marketplace idea, particularly the rationale that people in the marketplace act rationally in the receipt of speech); REDISH, supra note 153, at 46 (arguing that the marketplace rationale creates the danger that someone will decide that she has attained knowledge of truth and is justified in shutting off all contrary expression); SMOLLA, supra note 153, at 6-7 (detailing 
ideas underlies all speech-protective approaches to the First Amendment: the maximum quantum of speech must be disseminated by the greatest number of speakers to the greatest number of listeners, with those participating in the process deciding which ideas, information, and opinions to accept and which to reject. ${ }^{169}$

The marketplace-of-ideas concept cuts in two directions with regard to compelled expression. On one hand, compelling individuals to speak or to support financially other private speakers facilitates a greater amount of speech, likely from a greater number of speakers. Ensuring more speech from more sources arguably ensures the dissemination of a greater amount of speech and a broader, more diverse, and more dynamic marketplace of ideas. ${ }^{170}$ Compelled payments to support private speakers similarly enhance the amount of

problems with marketplace metaphor, including advantages to wealthy speakers, the continued presence of "shoddy ideas," and the infiltration of emotional distortions, such as appeals to hate, into the realm of ideas); Paul $\mathrm{H}$. Brietzke, How and Why the Marketplace of Ideas Fails, 31 VAL. U. L. REv. 951, 953-57 (1997) (criticizing the four implicit assumptions of the marketplace ideal); Calvert, supra note 167, at 61-62 (noting that the economic-based marketplace metaphor has been criticized and attacked, particularly on the grounds that truth does not trump falsehood and that the marketplace is skewed in favor of speakers with greater resources); Stanley Ingber, The Marketplace of Ideas: A Legitimizing Myth, 1984 DuKE L.J. 1,5 (1984) (describing the real-world conditions that interfere with the effective operation of the marketplace of ideas); Charles H. Lawrence III, If He Hollers Let Him Go: Regulating Racist Speech on Campus, 1990 DuKE L.J. 431, 468 (1990) (arguing that the marketplace of ideas permits racism and racist ideas to thrive); Marshall, supra note 167, at 2-3 (describing the argument that objective or transcendent truth is unknowable).

169. See REDISH, supra note 153, at 48 (arguing that "there is probably no expression of opinion or information that would not potentially affect" some individual life-affecting decisions and that the "marketplace-of-ideas concept as a protector of all such expression makes perfect sense"); see also id. at 102 (emphasizing the problem with regulations that impair the free flow of information and reduce the sum total of information or opinion disseminated); SMOLLA, supra note 153, at 5-6 (arguing that the inclusion of more justifications for the "transcendent importance of free expression" will lead an open society to "embrace principles protecting a richer range of expression"); Lillian R. BeVier, Rehabilitating the Public Forum Doctrine: In Defense of Categories, 1992 SUP. CT. REV. 79, 101-02 (1992) (discussing the Enhancement Model of the First Amendment, which assumes that "the widest possible dissemination of information from diverse and antagonistic sources is essential to the welfare of the public, and that individuals have a constitutionally protected interest in effective self-expression" (internal quotation omitted)); id. at 103 (arguing that the Enhancement Model demands rules that "will maximize the opportunities for expression"); Marshall, supra note 167, at 4 ("The value that is to be realized is not in the possible attainment of truth, but rather, in the existential value of the search itself.").

170. See Calvert, supra note 167, at 56-57 (arguing that government efforts to advance the quantity and range of available speech will be viewed favorably); Jacobs, supra note 11, at 446 (discussing "collective majority's power to compel its members to support the common purpose of adjusting the relative weights of the voices in the marketplace of ideas to promote more full dialogue and debate."); Jacobs, supra note 7, at 175-76 (arguing that promoting diverse expression might be a sufficient justification for compelled financing of private speech). 
speech available to listeners in the marketplace, furthering free speech interests of those listeners. ${ }^{171}$

For example, the ability to use all the money collected from dues payers without restriction, and without obligation to refund some portion, might enable the state bar in Keller to speak more often and about more subjects and issues without having to shoulder any administrative burdens in collecting and using moneys. Similarly, an additional voice espousing an additional idea would have been presented and heard as part of the aggregate message of the St. Patrick's Day Parade had GLIB been permitted to march. In this regard, the marketplace-of-ideas theory, while not necessarily requiring government to compel support for private speech, would not prohibit government from compelling support for private speakers if the compelled expression furthers the more-diverse-speech goals. ${ }^{122}$

On the other hand, by restricting government's power to compel expression, the First Amendment prevents government from manipulating, skewing, and distorting the marketplace. ${ }^{173}$ The marketplace remains, in a sense, free and unencumbered by government control of the manner in which speakers and messages are heard. Compelled support for private expression distorts the strength and popularity of the substantive positions advocated by those private entities favored with government-mandated funds. ${ }^{174}$ Money facilitates speech, and a greater amount of money facilitates a greater amount of speech, while a lesser amount of money likely reduces the amount of

171. See Calvert, supra note 167 , at 67 ("Viewed in the context of the audience's right to receive a diversity of messages, the marketplace intervention measure of mandatory fee assessments at public universities to support the speech of a myriad of student groups makes perfect sense.").

172. See Gaebler, supra note 7, at 1009 ("[W]hile compelled expression may infringe upon individual interests it should not be condemned as an interference with the "free marketplace of ideas."'); see also Jacobs, supra note 7, at 157 (arguing that the extent to which government compulsion enhances the expression that enters the marketplace should play a role in evaluating the constitutionality of compelled expression).

173. See Cantor, supra note 11, at 29 ("Potentially then, the free marketplace of ideas could be skewed in directions favored by the government."); Kamenshine, supra note 135, at 1106 (arguing that government support of speakers and ideas threatens the free marketplace of ideas necessary to self-government); id. at 1108-09 (arguing that governmental payment of funds to private speakers distorts the marketplace of ideas).

174. See Gaebler, supra note 7, at 1009 (acknowledging that government can create a false sense of support for a certain view by forcing expression of it); Jacobs, supra note 11, at 467 ("A danger of such speech-conscious government action is that it will distort public perceptions of the support that certain ideas have and thereby distort individual truth-seeking and self-government deliberations."); Redish \& Kaludis, supra note 44, at 1114 (arguing that compelled speech harms the interests of free expression by confusing the people about the actual strength and popularity of the substantive positions favored by the government). 
speech. ${ }^{175}$ If the state bar is able to use money collected from all its dues payers without extra administrative burdens to protect objectors, it will have more resources with which to advocate and spread its message in the name of the union. The greater amount of speech might suggest that the bar's views are more popular and powerful than they in fact are. Further, compelling an individual to support the organization's speech reduces the amount of money that individual has for her own expression, reducing the level of her own speech. ${ }^{176}$

The danger is that government, by choosing the speech that will be funded and heard, will favor some speakers, subject matters, and viewpoints over others, distorting the marketplace. ${ }^{17}$ One commentator suggests that the threshold focus in the compelled speech inquiry should be whether the government's purpose in compelling support for a given message is to manipulate the marketplace of ideas. $^{178}$

\section{Limiting the Category of Compelled Expression}

It is imperative that the category of unconstitutional compelled expression-those situations in which the objector's right is triggered-not extend too far. The compelled speech doctrine, to the extent it prohibits government-mandated utterance, presentation, or support of private expression, rests on a strong and significant theoretical concern for individual liberty interests. ${ }^{179}$ But there areand should be - times in which the political branches of government act as honest agents in support of free speech, facilitating and promoting public discourse, enhancing the ability of private speakers

175. Cf. Buckley v. Valeo, 424 U.S. 1, 19 (1976) (per curiam) (stating that restrictions on the amount of money that a group can spend on communication "necessarily reduces the quantity of expression by restricting the number of issues discussed, the depth of their exploration, and the size of the audience reached").

176. See Cantor, supra note 11 , at 27 (discussing argument that "compelled financial extractions deplete the economic resources of the payor and thereby diminish his expressive capacity"). But see Glickman v. Wileman Bros. \& Elliott, 521 U.S. 457, 470 (1997) ("The fact that an economic regulation may indirectly lead to a reduction in a handler's individual advertising budget does not itself amount to a restriction on speech.").

177. See Cantor, supra note 11 , at 29 (suggesting that, by reinforcing some private institutions, "aggregate expressive and political power accrues to the benefited institutions"); Redish \& Kessler, supra note 125, at 568 ("[G]overnment could choose to fund only those viewpoints with which it agreed, thereby dramatically skewing public debate and undermining First Amendment principles.").

178. See Jacobs, supra note 7, at 183.

179. See EMERSON, supra note 17, at 30 ("Forcing public expression of a belief is an affront to personal integrity."); see also supra notes 153-166 and accompanying text. 
to make their messages heard, and furthering individual liberty interests. ${ }^{180}$

Most obviously, government collects and expends taxes, fees, assessments, and other mandatory payments to establish, maintain, and provide forums dedicated to private expression. ${ }^{181}$ The public forum doctrine, one commentator argues, derives from the most basic mythological image of free speech: "an agitated but eloquent speaker standing on a soap box at Speakers' Corner, railing against injustices committed by the government, whose agents are powerless to keep the audience from hearing the speaker's damning words." ${ }^{.182}$

Public forums, and access to public forums, are essential to preserving individual liberty, democracy, and an open society, all of which can flourish only if citizens are "free to speak Truth to Power.",183 In fact, democratic government is obligated to provide such forums for private speakers and for private expression to ensure that people can speak and be heard, that there is broad, open dialogue, and that the greatest amount of expression is disseminated. ${ }^{184}$ Every community,

180. See Jacobs, supra note 17, at 1366 ("The permissible range of government action is different when it promotes speech, rather than restricts it.").

181. See EMERSON, supra note 17, at 645 ("One important way in which the government can affirmatively promote a system of freedom of expression is by making available to individuals and groups the facilities for engaging in expression."); BeVier, supra note 169, at 103-04 (arguing that under the Enhancement Model, the Public Forum Doctrine demands that government give effect to the broad affirmative command of the First Amendment); Jacobs, supra note 11, at 456 ("'[W] here the government creates and structures a public forum, its speech-conscious action may serve rather than thwart free speech clause values."); Jacobs, supra note 7 , at 176 ("[C]reating a public forum to promote diverse expression should be viewed as a justification that can meet strict review."); Kamenshine, supra note 23, at 110 (" $[\mathrm{W}]$ hen government provides a forum without requiring payment, this is a form of subsidization.").

182. Gey, supra note 12 , at 1538 .

183. Id.; see also BAKER, supra note 153, at 170-71 (arguing that the individual liberty interests underlying free speech mandate that government provide opportunities for expressive activities); SMOLLA, supra note 153, at 208 ("It is vital that an open culture recognize many of these traditional public forums.").

184. See BAKER, supra note 153, at 170 ("[T] he government must exhibit at least a minimal concern for people's freedom of assembly and expression-a mandate surely consistent with the constitutional status of these expressive activities."); SMOLLA, supra note 153, at 208 (arguing that, in a democracy, "[e] very city, village, and hamlet in the nation should have at least one central gathering point that is treated as a traditional public forum"); $i d$. at 209 (arguing that government must provide "green spaces" of discourse); BeVier, supra note 169, at 101 (arguing that the Enhancement Model of the First Amendment "sometimes imposes affirmative duties on government to maximize the opportunities for expression," such as through the creation of public forums); Bezanson \& Buss, supra note 11, at 1402 (arguing that inclusion of streets and parks as public forums "helps to satisfy the requirement in a democratic society that all individuals have some de minimis opportunity for expressing their views freely"); Gey, supra note 12, at 1538-39 ("The larger reality behind the myth of the debate on the public street-corner is that every culture must have venues in which citizens 
regardless of size, must establish-through government expenditure of compelled taxes and other payments to the public fisc-at least one "First Amendment "free-fire zone," locations or programs in which the First Amendment applies with undiminished force. ${ }^{185}$ That commitment carries with it the additional obligation to create new forums (by expending public moneys) when existing governmentowned property, such as parks and sidewalks, are insufficient to satisfy the free speech needs of the community. ${ }^{18}$

Moreover, because the paradigm of compelled expression has changed, so have the interests that must be balanced in the compelledexpression equation. ${ }^{187}$ In Wooley and Barnette, the constitutional problem arose because government compelled an individual to utter or display the government's message. ${ }^{188}$ The Barnette Court emphasized that the sole conflict was between the government and the rights of the individual; the refusal of one individual to present the government's message did not interfere with or deny the rights of others to do so. ${ }^{189}$ In the more recent and subtle cases, government compelled private presentation of, or financial support for, the speech of some private third-party speaker. ${ }^{190}$ A third liberty interest, that of the beneficiary of

can confront each other's ideas and ways of thinking about the world."); id. at 1538 (arguing that the public forum doctrine is a mechanism to effectuate the First Amendment's broad command to protect speech from government interference); Greene, supra note 17, at 66-67 (arguing for an understanding of government's speech power that ensures the robustness and equality of speech commons); Jacobs, supra note 7, at 176 (arguing that government's creation of a public forum to promote diverse expression satisfies strict scrutiny).

185. See SmOLLA, supra note 153, at 211.

186. BAKER, supra note 153, at 171 (arguing that in locations in which weather may prevent outdoor expressive activity, government cannot ban expressive activities in appropriate indoor locations, such as an auditorium); Bezanson \& Buss, supra note 11, at 1409 ("[T] he needs of individuals for free speech opportunities in a modern society have not been fully satisfied by the traditional public forum.").

187. See Kamenshine, supra note 23, at 102 ("'[C]ontemporary settings of coerced expression are generally less dramatic and more complex.").

188. See Wooley v. Maynard, 430 U.S. 705, 717 (1977) (holding that a state's interest in disseminating its own message "cannot outweigh an individual's First Amendment right to avoid becoming the courier for such message"); W. Va. State Bd. of Educ. v. Barnette, 319 U.S. 624, 642 (1943) (holding that compelled flag salute and pledge "invades the sphere of intellect and spirit" protected by the First Amendment); Gard, supra note 27, at 318-19 ("It is simply contrary to the democratic premise of the first amendment to allow the government to compel the unconsenting to use their person or privately owned property as a "mobile billboard' for the State's ideological message." (internal quotation omitted)); supra notes 2343 and accompanying text. at 293.

189. See Barnette, 319 U.S. at 630; Curtis, supra note 27 , at xxxii; Gard, supra note 27 ,

190. See, e.g., Hurley v. Irish-Am. Gay, Lesbian \& Bisexual Group, Inc., 515 U.S. 557, 559 (1995) (defining the issue as whether private citizens who organize a parade may be required by government to include among the marchers a private group imparting a message 
the compulsion-the private speaker whose message will be disseminated with the aid of the government mandate-must be added to the balance of interests, perhaps altering the outcome of that balance in some circumstances.

A broadly applied right to object to compelled presentation or financial support of a message or messenger, while protecting the liberty interests of the compelled speaker, reduces the sum total of expression. It inhibits the ability of the benefiting speakers (the expressive recipients of the benefits of the compulsion) to get out their messages or imposes financial and administrative burdens on the dissemination of that message. In Hurley, GLIB will be deprived of its most advantageous opportunity to present its message, the widely attended and watched St. Patrick's Day Parade, absent the compelled opportunity to march. ${ }^{191}$ A labor union obligated to refund dues payments to some compelled payers will have less money to spend on expression and must establish complicated administrative mechanisms to provide refunds and to oversee its collection and expenditures for expressive activities. ${ }^{192}$ Fewer speakers will be heard in the public forum if government is forced to refund moneys whenever certain objectionable speakers use the resources of that forum; the forum operates with decreased funds and increased administrative hassles. These hassles might compel government simply to shut down the forum, depriving private speakers of their best opportunity for expression. ${ }^{193}$

that the organizers do not wish to convey); Keller v. State Bar of Cal., 496 U.S. 1, 4-5 (1990) (involving individuals compelled to join and pay dues to an integrated state bar, which attempts to finance ideological and political activities with the collected dues); supra notes 44-112 and accompanying text.

191. See Hurley, 515 U.S. at 572.

192. Alternatively, a union or other organization could establish a separate fund to which contributions from members are voluntary and speak only through the resources from that fund. But this removes the organization's voice from the debate altogether; any expression is not that of the organization but of some particular subset of the organization's members. Compare Brudney, supra note 78, at 272 (arguing for segregated funds as an acceptable means of protecting dissenting shareholders), with Redish \& Wasserman, supra note 77, at 279 (arguing, with respect to corporations, that speech through the corporation's segregated fund is that of a subgroup of the corporation, not the corporation itself).

193. See Bezanson \& Buss, supra note 11, at 1427 ("The Abood precedent requires a remedial means that is unworkable because any system requiring optional fees or a way for students to opt out from paying for specified activities would be disruptive and expensive and thus ineffective."); see also Bd. of Regents of the Univ. of Wis. Sys. v. Southworth, 529 U.S. $217,232(2000)$ ("The First Amendment does not require the University to put the program at risk."); infra notes 342-352 and accompanying text. 
This is not to suggest that cases such as Hurley or Keller or Abood were wrongly decided - they were not. ${ }^{194}$ Nor is it to suggest that government should have power to invade individual interests by compelling people to utter messages they do not wish to utter or to provide financial support for private speakers and messages they do not wish to support-it should not.

This is to suggest that we sharply and narrowly define when an individual is, in fact, being compelled to utter or support private speech, so government may at certain times act as an honest agent facilitating broad public discourse by private speakers. As a rule, exceptions to the broadest dissemination of the greatest amount of speech, and any doctrine that will reduce the total amount of expression, must be "narrow, clear-cut, precise, and readily controlled."195 What we define as compelled expression similarly must be narrow, clear-cut, and precise; not every compelled payment from an individual that ultimately may result in private speech qualifies as compelled expression. This balances the liberty interests of compelled payers with the interests of willing expressive recipients of those payments, ensuring the dissemination of the greatest amount of speech within First Amendment bounds. ${ }^{196}$

We must establish limiting principles to define those circumstances in which the objector's right will be triggered. One important limiting principle already discussed is that taxpayers and other compelled funders cannot object to taxes and other mandatory payments made to a governmental entity, when used by government either for its own speech or for its own nonexpressive activities. ${ }^{197} \mathrm{We}$ consider several others.

194. But see Bezanson \& Buss, supra note 11, at 1433-34 (arguing that it is "just barely conceivable" that union membership entails support of the union message and that the objector's right should carry if there is risk of attribution to the payer); id. at 1427 (arguing that $A b o o d$ has been criticized because it is impossible to distinguish, in principle, from other, more pervasive ways in which individuals are taxed to support policies they abhor); Cantor, supra note 11, at 45-46 (suggesting an alternative, looser test for evaluating union expenditures).

195. See EMERSON, supra note 17, at 10 (arguing that the system of free expression must rest on the broadest protections and any narrow exceptions must be "clear-cut, precise, and readily controlled").

196. See REDISH, supra note 153, at 55 (arguing for balancing with a "thumb on the scales" in favor of speech); supra notes 169-178 and accompanying text.

197. See supra notes 113-152 and accompanying text. 


\section{Funds Used for Expression}

There is universal agreement that the activities funded by compelled payments must be expressive in order for objectors to state First Amendment claims. "By definition government cannot infringe upon individual interests by compelling expression unless what it compels constitutes expression.,"198 The liberty interest in individual conscience protected by the prohibition on compelled support for expression does not extend beyond situations in which the activities immediately and purposefully funded with compelled moneys are, in and of themselves, speech. For this reason, objections to government's ideologically objectionable nonexpressive activities, such as waging war or providing reproductive health services, are not constitutionally cognizable. ${ }^{199}$

This distinction between funding expressive and nonexpressive activities is the key to Wileman Bros. The Court there explained that Abood recognized only a right not to be compelled to contribute to an organization's expressive activities that conflict with one's freedom of belief, not a right not to be compelled to provide financial support for an organization that happens to conduct expressive activities. ${ }^{200}$ Where the expressive activity comprises only a small portion of the range of nonexpressive activities engaged in with compelled funds, the program must be understood as nonexpressive, such that payers may not object to any uses of their funds. ${ }^{201}$ This was precisely how the Court in United Foods distinguished Wileman Bros. and held that a different statutory program, funding only generic advertising with no

198. Gaebler, supra note 7, at 1010.

199. See Cantor, supra note 11, at 23 ("Yet such affronts to conscience through forced monetary support of government have never been deemed to be significant first amendment impingements."); see also Redish \& Wasserman, supra note 77, at 276 (arguing that corporate shareholders often must subsidize nonexpressive corporate activities, such as operating with low-wage laborers in foreign countries, which shareholders may find ideologically objectionable).

200. See Glickman v. Wileman Bros. \& Elliott, 521 U.S. 457, 471 (1997).

201. See id. at 469 (discussing "assessments used to fund collective advertising, together with other collective activities"); id. (stressing the importance of the statutory context, in which the objecting funders act as "part of a broader collective enterprise in which their freedom to act independently is already constrained by the regulatory scheme"); $i d$. at 475 ("The basic policy decision that underlies the entire statute rests on an assumption that in the volatile markets for agricultural commodities the public will be best served by compelling cooperation among producers in making economic decisions that would be made independently in a free market."); Jacobs, supra note 7, at 174 (arguing that Wileman Bros. suggests that forced contributions, even for expression, will be constitutional if germane to the presumably nonspeech purposes for the compulsion); supra notes 88-102 and accompanying text. 
complementary nonexpressive activities, triggered free speech interests and could not use objecting payers' moneys to fund those activities. ${ }^{202}$ Thus, where private activities funded through government-mandated payments are entirely (or perhaps primarily) nonexpressive, First Amendment strictures will not apply and the rights of objecting payers will not be triggered.

\section{Disagreement with the Message Funded}

Another potential limiting principle would be a requirement that the objector disagree with the message that she is forced to utter or financially support. Commentators properly reject such a limitation because the existence of an objector's claim should not turn on the presence or absence of disagreement with the compelled message. ${ }^{203}$

The right at issue is the right to refrain from speaking, grounded in the individual's liberty interest in both her self-perception and selfpresentation. ${ }^{204}$ The infringement on those interests results from the compulsion to speak or to pay for the speech of others, regardless of the compelled message and regardless of whether the compelled speaker or payer disagrees with that message. ${ }^{205}$ It is true that the Court has noted and emphasized the presence of substantive disagreement with the compelled message in several cases. ${ }^{206}$ It also is

202. See United States v. United Foods, 533 U.S. 405, 412-413 (2001) (emphasizing the missing features, including the fact that almost all the funds collected were used for generic advertising, that there were no marketing orders regulating the sale or production of mushrooms, and no industry exemption from antitrust laws); id. at 415 (" $[\mathrm{H}]$ ere the statute does not require group action, save to generate the very speech to which some handlers object."); id. ("[T] he compelled contributions for advertising are not part of some broader regulatory scheme."); supra notes $105-112$ and accompanying text.

203. See Gaebler, supra note 7, at 1005 ("Whether or not the individual agrees with the views he is required to express, and whether or not others perceive his coerced expression as sincere make no difference."); see also Wileman Bros., 521 U.S. at 489 (Souter, J., dissenting) ("What counts here, then, is not whether respondents fail to disagree with the generalized message of the generic ads that California fruit is good, but that they do indeed deny that the general message is as valuable and worthy of their support as more particular claims about the merits of their own brands."); W. Va. State Bd. of Educ. v. Barnette, 319 U.S. $624,634-35$ (1943) (suggesting that the right to object does not turn on the objector possessing particular views).

204. See Gaebler, supra note 7, at 1004-05 (grounding the protection against forced expression in an individual's ability to control her presentation to the world and in her individual conscience); see also Wooley v. Maynard, 430 U.S. 705, 714 (1977) (holding that the right not to speak is a component of individual freedom of mind); supra notes 157-163 and accompanying text.

205. See Gaebler, supra note 7, at 1005.

206. See, e.g., United Foods, 533 U.S. at 410-11 ("First Amendment concerns apply here because of the requirement that producers subsidize speech with which they disagree."); Hurley v. Irish-Am. Gay, Lesbian \& Bisexual Group, Inc., 515 U.S. 557, 574 (1995) ("[T]he 
true that the injury to such interests will be greater when the message foisted upon a person is offensive or objectionable. ${ }^{207}$

One presumably would be less likely to object either to uttering a message with which one agrees or to supporting the expressive activities of an organization with which one agrees; perhaps the constitutional challenge does not arise in the absence of disagreement. If, for example, the organizers of the South Boston St. Patrick's Day Parade did not object to GLIB's message, they would not have attempted to bar the group's banner from the parade in the first place. ${ }^{208}$

But that is not tantamount to suggesting that disagreement is the sine qua non of the free speech right. Such a state-of-mind requirement is properly understood as a make-weight, a point strengthening the Court's analysis, without becoming a necessary condition on the right. ${ }^{209}$ For example, it is unlikely that the Maynards would have lost their case if they simply did not wish to promote the state slogan on their car, regardless of whether they found the message "Live Free or Die" morally objectionable. ${ }^{210}$ Similarly, a requirement that an individual give money directly to some private expressive organization, even when she has complete freedom to choose an organization mirroring her ideas and desired messages, nevertheless invades her interests in controlling the time and content of the messages she presents to the world. ${ }^{211}$

Council clearly decided to exclude a message it did not like from the communication it chose to make, and that is enough to invoke its right as a private speaker to shape its expression by speaking on one subject while remaining silent on another."); Wooley, 430 U.S. at 715 ("The First Amendment protects the right of individuals to ... refuse to foster, in the way New Hampshire commands, an idea they find morally objectionable.”).

207. See Kamenshine, supra note 23, at 115 ("Of course, where a party is compelled to utter, display, subsidize, or facilitate an opposed political or religious message, the government's action is especially objectionable."); Redish \& Kaludis, supra note 44, at 1118 ("The publicly humiliating and personally degrading effects may be even greater when private individuals are called upon actually to mouth words and thoughts which they find abhorrent.").

208. Moreover, the parade organizers likely agreed with some portion of GLIB's message, the part about being Irish and proud of their Irish heritage. See Hurley, 515 U.S. at 561,570 .

209. See Kamenshine, supra note 23, at 115 ("[I]t is not surprising that the Court would allude to such disagreement where it exists.").

210. See id. at 115-16 ("Nor is it reasonable to suppose that after Wooley, a motorist could be compelled to display a state's motto as long as he or she agreed with, or was at least neutral as to its sentiment."); $i d$. at 115 (arguing that the flag salute could not be imposed on a student who admitted to agreeing with the sentiments of the Pledge of Allegiance, but chose not to make her sentiments public by reciting it).

211. See Kamenshine, supra note 23, at 115 (" $[\mathrm{I}] \mathrm{t}$ is hard to imagine that the ... Court would have upheld a requirement that during a presidential election, each person must contribute to the candidate or party of his or her choice."). 
The exception to this understanding is Wileman Bros., where the Court emphasized that the central message of the generic advertising was "designed to serve the producers' and handlers' common interest" and that "it is fair to presume that they agree with the central message of the speech."212 In other words, because the objecting funders could not have disagreed with the message of the generic advertisements, they did not have a valid First Amendment claim.

But Wileman Bros. marks a sharp doctrinal departure, arguably taking a step towards undoing all protection against compelled funding of private expression. ${ }^{213}$ The decision contradicted the statement in Hurley, just two years earlier, that there need not be any articulable message presented for an objector to challenge the compulsion. ${ }^{214}$ If there need not be any clear and articulable message, there need not be disagreement with any message for an objecting payer to challenge a funding requirement. In any event, the Court apparently backed away from this notion in United Foods, stating that it is enough that the objecting payer wishes to present a different message, even if she does not entirely disavow the message to be supported by the compelled payments. ${ }^{215}$

\section{Public Connection Between the Funder and the Message}

A third possible limiting factor is a requirement that the compelled speaker be linked publicly with the compelled message or messenger. This is not an issue in cases involving compelled presentation or utterance of a message, where the link will be readily apparent. The nexus concern arises only in compelled funding cases, where the connection between the speech of the organization and the single compelled payer will not always be clear.

Some commentators have been explicit in demanding this element. Professor Cantor argues that the "critical issue for first amendment purposes is whether the payor is required to associate with or appear to endorse in some fashion a distasteful cause selected by the

212. Glickman v. Wileman Bros. \& Elliott, 521 U.S. 457, 462, 470 (1997).

213. See supra notes $89-112$ and accompanying text.

214. See Wileman Bros., 521 U.S. at 488-89 (Souter, J., dissenting).

215. See United States v. United Foods, 533 U.S. 405, 411 (2001) (stating that plaintiff "wants to convey the message that its brand of mushrooms is superior to those grown by other producers," as opposed to the message "that mushrooms are worth consuming whether or not they are branded"); id. ("[T]here is no apparent principle which distinguishes out of hand minor debates about whether a branded mushroom is better than just any mushroom.'); see also Wileman Bros., 521 U.S. at 489 (Souter, J., dissenting) (arguing that it is enough that one "merely wishes to support a different act of expression"). 
government." ${ }^{, 216}$ Professors Bezanson and Buss echo this view, arguing that the real question "should be whether the government places a person in such a relationship with objectionable ideas that a reasonable observer will see the ideas as that person's own."217 Similarly, Professor Gaebler argues that an infringement on free speech interests is established only when the individual somehow is identified with some message. ${ }^{218}$ He envisions a continuum. As the compelled expression becomes less personal and less direct, the payer's association with the message diminishes and it becomes less likely that she or any listeners will ascribe the views expressed to her. ${ }^{219}$ "Eventually a point is reached where the level of personal involvement is so minimal and the resulting nexus between the individual and the message so remote that no legally cognizable infringement of negative first amendment interests occurs. ${ }^{\prime 220}$

Justice Souter, concurring in the judgment in Southworth and finding no compelled speech problem, distinguished Abood and Keller precisely because the relationship between the fee payer and the ultimately objectionable expression was far more attenuated than in those earlier cases. ${ }^{221}$ In the earlier cases, the individual had been required to join or at least pay money directly to the very organization presenting objectionable messages; the "connection between the forced contributor and the ultimate message was as direct as the unmediated contribution to the organization doing the speaking.,2222 This suggests that the presence or absence of some nexus or identification between individual and organizational message will make a difference in the outcome of compelled funder cases.

In fact, such a nexus should not be necessary; "the central point is that compelled subsidization is objectionable even if there is no identification between the contributor and the subsidized expression."223 The right at issue is to refrain from speaking and the

216. Cantor, supra note 11 , at 25.

217. Bezanson \& Buss, supra note 11, at 1433.

218. See Gaebler, supra note 7, at 1011; id. at 1023 ("[T] here can be no infringement of individual interests unless compliance with a government requirement somehow identifies the individual with a message or point of view.").

219. See id. at 1013-14.

220. See id. at 1014; see also id. at 1022-23 (arguing that the Abood Court correctly held that payments for ideological speech violated these free speech interests and that the Court correctly held that this interest was outweighed for some issues by the interest in maintaining agency shops).

221. 529 U.S. 217,240 (2000) (Souter, J., concurring in the judgment).

222. See id. (Souter, J., concurring in the judgment).

223. Kamenshine, supra note 23, at 116. 
sole point is that an individual should not be forced to support private speech. That protection is abridged by the very requirement that the individual do so, regardless of any connection to the message that might or might not be apparent to a reasonable listener. The point of the protection is that, while an individual cannot stop a private speaker from presenting an offensive message, she may decline to pay for it in most circumstances. ${ }^{224}$

Moreover, Professor Gaebler's own model commands that no nexus to the ultimate message is required. The dignitary interest in freedom of conscience rests on an inward focus on the individual's own mind-her self-perception and internal feelings of powerlessness, shame, and disgrace from her inability to remain silent as a result of the government compulsion. ${ }^{225}$ Professor Gaebler concedes that a compulsion to support some idea causes feelings of humiliation, even if no one else witnesses or knows of the payer's actions. ${ }^{226}$ If the very requirement of supporting private speech requires a submission of mind and impinges that internal vision of self - by preventing the payer from controlling the messages that she enables - her freedom of conscience is violated, regardless of whether or not the world or a reasonable person perceives a nexus between payer and a particular message. Moreover, cognitive dissonance, resulting from involuntary internalization and adoption of the government-mandated message, is an entirely personal, internal subconscious process of confusion. ${ }^{227}$ Such dissonance is unaffected by how the reasonable outside world views or understands the message and the individual's connection to it.

\section{A LIMITING TEST FOR COMPELLED EXPRESSION}

We incorporate aspects of these limiting principles into a threepart model for determining when an objecting payer's right has been triggered. This test properly and sufficiently cabins the breadth of what we understand as compelled support for expression, ensuring that the greatest amount of speech is disseminated, striking a proper

224. $C f$. Nat'l Endowment for the Arts v. Finley, 524 U.S. $569,595-96$ \& n.2 (1998) (Scalia, J., concurring in the judgment) ("Avant-garde artistes such as respondents remain entirely free to épater les bourgeois, they are merely deprived of the additional satisfaction of having the bourgeoisie taxed to pay for it." (internal footnote omitted)).

225. See Gaebler, supra note 7, at 1005-06; see also Wooley v. Maynard, 430 U.S. 705, 714 (1977) (stating that the right to refrain from speaking is a component of the individual freedom of mind); supra notes 159-163 and accompanying text.

226. See Gaebler, supra note 7, at 1006.

227. See Redish \& Kaludis, supra note 44, at 1114; supra notes 161-163 and accompanying text. 
balance, and protecting the interests in individual liberty underlying the First Amendment right not to speak.

First, we examine who receives the compelled funds-who is the immediate, direct, and designated recipient of the compelled payments. The objector's right exists only where the recipient is the ultimate speaker; no right is triggered where that recipient is the government. ${ }^{228}$ Second, we look to the immediate, direct, intended, and designated use of those funds. A payer has a free speech objection only if the immediate use of the compelled funds is expressive, only if the funds leave the payer's hands and go directly for purposes or activities that may be understood as, in and of themselves, speech. ${ }^{229}$ Third, the payments by the funders to the private speaker must be compelled or coerced by government, mandated by law or other fiat; absent that compulsion, no free speech right is implicated. ${ }^{230}$

The question, in short, is whether the compelled payer is required by the government to pay money directly to, or for the express benefit of, a private recipient for use by that recipient for expressive activities. The focus must be on where the money goes immediately after it leaves the payer's hands and for what purpose; that is, whether money is paid by the funder either directly to a speaker or to the government but earmarked for immediate transfer to a specific, known, identified speaker. Such funds must be used for expressive activities. Where money is paid to government generally, or alternatively, where funds are used for nonexpressive purposes, the payer has no First Amendment right to object to the compelled payment or the uses of that payment. Moreover, unlike Woodward and Bernstein, we do not "follow the money."231 We do not look beyond the initial transfer of money from the compelled payer to the immediate recipient and the initial use of those funds. Any speech that might occur farther down the road with the help of, or as a result of, the funds transferred in that initial compelled payment is irrelevant to the objector's right.

228. See supra notes 113-152 and accompanying text.

229. See supra notes 198-202 and accompanying text.

230. See United States v. United Foods, Inc., 533 U.S. 405, 413 (2001) ("[A] threshold inquiry must be whether there is some state imposed obligation which makes group membership less than voluntary ....); Cantor, supra note 11, at 19 ("A first amendment violation would not seem to arise without government prescription of a message or forced identification with, or affirmation of, a message by the payor.").

231. See All THE PREsident's MEN (MGM 1974) (depicting conversation between Washington Post reporter Bob Woodward and confidential informant Deep Throat, in which Deep Throat tells Woodward to "follow the money" in uncovering the connection between the Watergate burglary and the Nixon White House). 
This analysis defeats the objector's right in the absence of a close nexus between the individual payer and some private expression by the recipient of the funds. This is not equivalent to requiring a public nexus between the forced contributor and a specific, articulable message or point of view, which is irrelevant to the constitutional injury. ${ }^{232}$ The focus instead is on a direct connection between the funds and speech, some expressive activity. If that connection is lacking because the uses of the money are not speech or because the immediate recipient of the funds is not a speaker, the payer's First Amendment interests are not implicated. However, if the thing funded is expressive, the payer's interests are implicated, whether or not the payer is publicly linked to the content of that expression.

This is a two-step analysis. An objecting payer first must satisfy all three elements of this model in order for her First Amendment interests to be triggered. If she meets all three elements, we next consider whether she prevails on her claim; in the funding context, this means applying the germaneness analysis of Lehnert, Keller, and Abood to determine if the expressive use of the compelled funds is constitutionally permissible. ${ }^{233}$ If the payer does not satisfy all three elements, the objector's right never was triggered, the inquiry ends at the first step, and the compelled payment program survives constitutional scrutiny.

This model justifies the outcomes of some prior compelled funding situations. For example, in Keller, the plaintiffs were compelled by law to join and pay dues directly to the state bar, which used those dues to fund its own expressive ideological and political activities. ${ }^{234}$ To the extent that some of the Bar's activities were nonexpressive-examining applicants for admission to practice, disciplining members for misconduct, formulating rules of professional conduct, and studying changes in court procedures ${ }^{235}$-the objecting dues payers' rights were not triggered. To the extent that the funded actions were expressive-lobbying or litigating on a range of contested political and social issues - the objecting dues payers' rights

232. See supra notes $216-227$ and accompanying text.

233. See Jacobs, supra note 7, at 174 ("[C]ontributions, even for speech, may be constitutional if germane to the (presumptively nonspeech) purpose for the compulsion."); see also Glickman v. Wileman Bros. \& Elliott, 521 U.S. 457, 484 (1997) (Souter, J., dissenting) ("[G]overnment retains its full power to regulate commercial transactions directly, despite elements of speech and association inherent in such transactions."); supra notes 56112 and accompanying text.

234. Keller v. State Bar of Cal., 496 U.S. 1, 4 (1990).

235. See id. at 5. 
were triggered, requiring consideration of which of those expressive activities were germane to its purposes and could be paid for with dues from objecting members. ${ }^{236}$

In United Foods, the objector's right was triggered because the industry assessments mandated by the government were paid directly from industry members to the Mushroom Council, and the Council used the funds exclusively for product advertising, an expressive activity. ${ }^{237}$ Turning to the second step, the program was invalid because the Mushroom Council's sole purpose was the creation of generic advertising, meaning that the compelled expression was not germane to any nonexpressive purpose independent of the speech itself..$^{238}$

Finally, in the corporate speech context, although shareholders pay money directly to the corporation and the corporation uses those moneys for its expressive activities, government never compels individuals to pay money to that corporation. ${ }^{239}$ The compelledshareholder argument fails on the absence of actual government compulsion.

By contrast, in Wileman Bros., tree-fruit industry members paid assessments to committees of industry members appointed by the Secretary of Agriculture, which funds were used for a variety of expressive and nonexpressive activities, pursuant to marketing orders issued by the Secretary through the committees. ${ }^{240}$ Our model partially explains the result because the funded activities primarily were nonexpressive, involving a range of collective nonexpressive industry economic and commercial activities, pursuant to a broad federal regulatory scheme that constrained independent commercial activity. ${ }^{241}$ Such nonexpressive use of compelled funds would not trigger the rights of the objecting payers. ${ }^{242}$

\section{See id. at 5, 15-16.}

237. United States v. United Foods, Inc., 533 U.S. 405, 408 (2001).

238. See id. at $415-17$; id. at 415 (rejecting notion that speech may be germane to itself).

239. See supra notes $77-88$ and accompanying text.

240. Glickman v. Wileman Bros. \& Elliott, 521 U.S. 457, 461-62 (1997).

241. See id. at 468-69; see also United Foods, 533 U.S. at 415 (distinguishing Wileman Bros. because the mushroom subsidies do "not require group action, save to generate the very speech to which some handlers object").

242. This is not to endorse the analysis or outcome in Wileman Bros., because the majority erred with its all-or-nothing approach. The Court should have analyzed the Committee's expressive expenditures separately from its nonexpressive expenditures, as it did in the earlier union and organization cases. See supra notes 56-76 and accompanying text. The Court should have recognized that the plaintiffs' rights were triggered by the expenditures for generic advertising; payers were compelled by federal law to give money to the Committee, which used the money for expressive activities. The Court then should have 


\section{OBJECTORS' Rights IN A NEW CONTEXT .}

Into this doctrinal and theoretical mix came five students from the University of Wisconsin-Madison, who argued that their free speech rights were infringed by the University's use of their mandatory student activities fees to fund private student organizations engaging in political and ideological expression. ${ }^{243}$ An objecting payer's claim in this context was not entirely new; several commentators have analyzed the issue of mandatory student fees at public universities as a compelled-expression concern, reaching varied conclusions. ${ }^{244}$ Southworth became the most visible of these cases.

\section{A. Background and Lower Courts}

The University of Wisconsin required all full-time students to pay a mandatory (students could not receive their grades or diplomas if the fees were unpaid) student activities fee, of approximately $\$ 165$ per semester. $^{245}$ A portion of the fees was placed in a common fund controlled and administered by the student government and distributed to a range of registered student organizations and community-based service organizations for their extracurricular activities, many of which were expressive, political, and ideological in nature. ${ }^{246}$

Registered student organizations obtained funds in any of three ways. First, and most common, the organization received money from the Student Government Activity Fund, which could be used to support operations, events, and travel expenses central to the organization's purpose. ${ }^{247}$ Second, approximately fifteen organizations obtained funds from the General Student Services Fund for on-campus services

proceeded to the second step, of whether those expenditures, although expressive, nevertheless were germane to the organization's primarily nonspeech purposes so as to be permissible.

243. See Bd. of Regents of the Univ. of Wis. Sys. v. Southworth, 529 U.S. 217, 226-27 (2000); Southworth v. Grebe, 151 F.3d 717, 718-19 (7th Cir. 1998); see also Calvert, supra note 167 , at $69-70$; Jacobs, supra note 11 , at $440-41$.

244. See Cantor, supra note 11, at 48 (arguing that the use of mandatory fees by private student groups was permissible, as long as the funds were "available on an equivalent basis to any student group satisfying neutral criteria," the group performed a "neutral service function," and the "funded group's activities [were] primarily directed to a student audience"); Jacobs, supra note 11 , at 442 (noting the conflicting results reached by lower courts in previous mandatory student fees cases).

245. See Southworth, 529 U.S. at 222; Grebe, 151 F.3d at 719.

246. See Grebe, 151 F.3d at 719-20; Bezanson \& Buss, supra note 11, at 1423; Calvert, supra note 167, at 69-70.

247. See Southworth, 529 U.S. at 223-24; Calvert, supra note 167, at 69. 
and for political and ideological activities. ${ }^{248}$ Third, an organization could have its funding approved by a referendum vote of the student body. ${ }^{249}$ Organizations generally received funds on a reimbursement basis, submitting invoices and receipts to the university for expenses incurred, rather than in a lump-sum payment in advance of the expenditures. ${ }^{250}$

It was undisputed that the program distributed funds to the organizations in an entirely viewpoint-neutral manner. ${ }^{251}$ Nevertheless, the complaining students objected to any portion of their fees going to eighteen organizations that engaged in political and ideological activities that conflicted with their politically conservative, Christian beliefs. ${ }^{25}$ The objectionable groups included, among others, the Wisconsin Public Interest Research Group; the Lesbian, Gay, Bisexual Campus Center; the International Socialist Organization; and Amnesty International. ${ }^{253}$ The students sought either a pro rata refund of the money that went to these groups or the opportunity to designate in advance those organizations to which they did not want to give any portion of their moneys. ${ }^{254}$

The district court concluded that the University could not force objecting students to fund private organizations that engage in political and ideological activities, speech, and advocacy; the court enjoined the use of the objectors' fees to fund those groups and required the university to establish an opt-out system. ${ }^{255}$ The United States Court of Appeals for the Seventh Circuit affirmed. The court of appeals first determined that the Supreme Court had instructed it as to the proper analysis, in dicta in Rosenberger v. Rector \& Visitors of University of Virginia, ${ }^{256}$ where the Court noted that the precise issue of student payers objecting to funding a student activities fund was not before it and cited to Keller and Abood. ${ }^{257}$ From this single sentence, the Seventh Circuit concluded that the Supreme Court had "directed" it

248. See Southworth, 529 U.S. at 224; Grebe, 151 F.3d at 720. at 69 .

249. See Southworth, 529 U.S. at 224; Grebe, 151 F.3d at 720; Calvert, supra note 167,

250. See Southworth, 529 U.S. at 225.

251. See id. at 234; Calvert, supra note 167 , at 70.

252. See Grebe, 151 F.3d at 720; Calvert, supra note 167, at 70.

253. See Grebe, 151 F.3d at 720-21; Calvert, supra note 167, at 70.

254. See Grebe, $151 \mathrm{~F} .3 \mathrm{~d}$ at 718.

255. See id. at 718,722 .

256. 515 U.S. 819 (1995) (holding that the University violated the First Amendment by denying a student organization access to money from student activities fund).

257. See Grebe, 151 F.3d at 722 (quoting Rosenberger, 515 U.S. at 840). 
and "led" it to the Kellerl Abood analysis for use when that issue did arise. ${ }^{258}$

The court of appeals then applied the three-part germaneness analysis formalized in Lehnert. ${ }^{259}$ The University argued that funding expressive student organizations was germane to education because the funding program permitted more diverse expression on campus. ${ }^{260}$ But the court held that germaneness could not be construed so broadly as to include the forced funding of private political speech within the concept of education. ${ }^{261}$ Any educational benefit that students might derive from such private political speech was incidental and secondary to the primary goal of the funded organization, the promotion of its ideological beliefs. ${ }^{22}$ Such incidental educational benefit did not justify infringing on the First Amendment rights of the dissenting students. ${ }^{263}$ The court also emphasized that most private student organizations did not even apply for funding, suggesting that funding is not even germane to the existence and activities of the organizations, much less to education. ${ }^{264}$ The funding of such private expression with mandatory fees could not be germane to this constricted view of the University's interest in education.

Second, the court found no "vital policy interests of the government" that could justify the use of compelled fees in this manner. ${ }^{265}$ There was no "common cause" between the private organizations engaging in speech and the objecting students who were funding them, as with the collective bargaining goals of a labor union. $^{266}$ Nor was there a free-rider problem, because the private organizations that the plaintiffs objected to funding did not act in a representative capacity for the students and much of the organizations' expressive activities provided no benefit to the objecting students. ${ }^{267}$

258. See id. at 722-23.

259. Lehnert v. Ferris Faculty Ass'n, 500 U.S. 507, 519 (1991); see supra notes 73-76 and accompanying text.

260. See Grebe, 151 F.3d at 724.

261. See id.

262. See id.; id. at 726 (stating that any training an organization provides its student members is secondary to the stated objective of a "frankly ideological bent") (quoting Galda v. Rutgers, 772 F.2d 1060, 1065 (3d Cir. 1985)).

263. See id. at 726 .

264. See id. at 725 .

265. See id. at 727 .

266. See id. at $727-28$.

267. See id. at 728; see also Cantor, supra note 11, at 48 (emphasizing the requirement that only on-campus activities should be exempt from an objector's challenge). 


\section{B. Southworth in the Supreme Court}

The Supreme Court unanimously reversed. ${ }^{268}$ Justice Kennedy, writing for six justices, began by emphasizing that the University had exacted the mandatory fees "for the sole purpose of facilitating the free and open exchange of ideas by, and among, its students."269 Nevertheless, the objecting students were entitled to insist upon certain operational safeguards with respect to the expressive activities they were compelled to fund. ${ }^{270}$

The student activities fund, the Court said emphatically, is "not a public forum in the traditional sense of the term.,"27! But public forum cases were "instructive here by close analogy" in establishing a standard of protection, even though public forum cases typically involve claims for access to the forum, not objections to funding it. ${ }^{272}$ The requirement of viewpoint neutrality, controlling in public forum cases, also was sufficient to protect the rights of objecting students. ${ }^{273}$

The Kellert Abood germaneness standard, on which the lower courts had relied, was "neither applicable nor workable in the context of extracurricular student speech at a university."274 The Court recognized that the mandatory fees infringed on the speech and beliefs of the compelled student funders, but found that the germaneness standard "becomes all the more unmanageable in the public university setting, particularly where the State undertakes to stimulate the whole universe of speech and ideas.",275 The Court stressed the vast range of speech that the university sought to encourage and enable and the university's power to determine that "its mission is well served if students have the means to engage in dynamic discussions of philosophical, religious, scientific, social, and political subjects" beyond the four walls of the lecture hall. ${ }^{276}$

The requirement of viewpoint neutrality in the funding system became the operational principle and the proper measure of protection

268. Bd. of Regents of the Univ. of Wis. Sys. v. Southworth, 529 U.S. 217, 219 (2000).

269. See id. at 229; see also Calvert, supra note 167, at 73-74 (summarizing majority opinion).

270. See Southworth, 529 U.S. at 229.

271. See id. at 230.

272. See id. at 229-30.

273. See id. at 230, 233-34.

274. Id. at 230; see also id. at 231 ("The standard of germane speech as applied to student speech at a university is unworkable ....").

275. Id. at 232 ("It is not for the Court to say what is or is not germane to the ideas to be pursued in an institution of higher learning.").

276. See id. at 233 . 
for objecting students. ${ }^{27}$ Because the parties had stipulated that the main funding program was viewpoint neutral, the program was consistent with the First Amendment. ${ }^{278}$ However, the Court expressed reservations about the referendum portion of the program and remanded for further inquiry because it was not clear that this funding mechanism was viewpoint neutral. ${ }^{279}$ The referendum process "substitutes majority determinations for viewpoint neutrality", undermining the minority views it is intended to protect. ${ }^{280}$

Justice Souter, joined by Justices Stevens and Breyer, concurred only in the judgment, suggesting that "the First Amendment interest ... here is simply insufficient to merit protection by anything more than the viewpoint neutrality already accorded by the University." The question was not whether the University was required to adhere to viewpoint neutrality, but whether, having done so, the plaintiffs were entitled to relief from that specific scheme. ${ }^{282}$ The concurring opinion agreed that the main portion of the student activities fund program was constitutionally valid. ${ }^{283}$

Justice Souter focused on how closely the circumstances of mandatory student activity fees resembled the Court's previous compelled speech cases, concluding that in the prior cases "the government was imposing far more directly and offensively on an objecting individual than collecting the fee that indirectly funds the jumble of other speakers' messages in this case."284 Justice Souter agreed that Keller and Abood did not control. ${ }^{285}$ The relationship between the fee payer and the ultimately objectionable expression was "far more attenuated," with the student funding only a distributing agency having no social, political, or ideological character and itself engaging in no expression. ${ }^{286}$ Further, the challenged fees supported a program aimed at broadening public discourse. ${ }^{287}$

277. See id. at 233-34.

278. See id. at 234.

279. See id. at 235-36.

280. See id. at 235 ("Access to a public forum, for instance, does not depend upon majoritarian consent.").

281. Id. at 236 (Souter, J., concurring in the judgment).

282. See id. (Souter, J., concurring in the judgment).

283. Id. (Souter, J., concurring in the judgment).

284. See id. at 239-40 (Souter, J., concurring in the judgment); see also id. at 239 (Souter, J., concurring in the judgment) (arguing that the fee program did not modify any message that the objecting student wishes to make and did not require the student to bear the offensive message personally, let alone affirm a moral or political commitment).

285. See id. at 240 (Souter, J., concurring in the judgment).

286. See id. (Souter, J., concurring in the judgment).

287. See id. at 240-41 (Souter, J., concurring in the judgment). 
Finally, Justice Souter emphasized the government's interest in education and the fact that some educational value will be derived from the expressive activities supported by mandatory fees. ${ }^{288} \mathrm{He}$ noted that this dispute occurred within the university setting, where students inevitably are required to support the expression of personally offensive viewpoints. ${ }^{289}$ Course offerings, even more directly and obviously offensive and funded by tuition payments, need not be viewpoint neutral; ${ }^{290}$ neither should a similarly expressive extra curricular program.

\section{Problems with the Court's Approach to Southworth}

Commentators have suggested that the Supreme Court's decision in Southworth reflects the triumph of the marketplace of ideas and of the governmental interest in enabling a broad range of diverse expression - particularly in the unique context of the university-over the interests of objecting funders. ${ }^{291}$ Justice Kennedy's opinion arguably suggests that, at least in some cases, the marketplace metaphor compels rejection of an objector's claim in favor of an enhanced and broader range of voices and ideas in the marketplace. ${ }^{292}$ The University manipulated the marketplace through the funding program, but in a way that sought to further the "common purpose of adjusting the relative weights of the voices in the marketplace of ideas to promote more full dialogue and debate. ${ }^{2033}$ In essence, the argument goes, where government, particularly a university, seeks to encourage diverse public expression, the arguments of objecting funders will fail. ${ }^{294}$

288. See id. at 242 (Souter, J., concurring in the judgment).

289. See id. at 242-43 (Souter, J., concurring in the judgment).

290. See id. at 243 (Souter, J., concurring in the judgment) ("The University need not provide junior years abroad in North Korea as well as France, instruct in the theory of plutocracy as well as democracy, or teach Nietzsche as well as St. Thomas.").

291. See Calvert, supra note 167 , at 58 ("The bottom line, then, is that the entire decision in Southworth can be interpreted through a basic understanding of one principlethe privileged and well-ensconced position of the marketplace of ideas in both First Amendment jurisprudence and, in particular, academia."); Jacobs, supra note 11, at 443 ("The difference relied upon by the Court in rejecting application of the germaneness standard to the student fee context is the 'vast unexplored bounds' of the speech public universities seek to encourage.").

292. See Southworth, 529 U.S. at 234.

293. Jacobs, supra note 11, at 446; see Calvert, supra note 167, at 77 ("Mandatory fee assessments ... serve to help place more ideas in the university marketplace.").

294. See Calvert, supra note 167, at 75-76 (arguing that Southworth"signals a triumph for the concept of tolerance within the university marketplace" and that people must "tolerat[e] the speech of others with whom [they] may disagree"); Jacobs, supra note 11, at 
There are several problems with the Court's analytical model. First, Justice Kennedy's opinion can be read not as rejecting application of the germaneness standard of Keller/Abood, but simply as applying that standard more liberally than did the Seventh Circuit. According to the majority, the university possesses broad power to define its educational mission and interest, to determine that this mission includes dynamic discussions on a limitless range of subjects outside the four walls of the classroom, and to impose the mandatory fee to sustain the dialogue to those ends. ${ }^{295}$ It was not for the Court to second-guess that determination of germaneness. ${ }^{296}$

But this merely restates the idea that the private speech funded by compelled student fees is germane to the university's educational mission and purpose, under an expansive definition of that educational mission and purpose. In other words, the Supreme Court did not decline to ask what speech is germane. Instead, it asked the question and found a far broader understanding of what private expression is germane to the unique setting of the public university. ${ }^{297}$

The Court did not grasp the real reason to completely reject the application of the germaneness test. The university is in no way analogous to a union or professional association and the university's funding system is in no way analogous to the system of organization dues. In Abood and its progeny, government required individuals to join, or give money to, private organizations which used that money for their own expressive purposes. ${ }^{298}$ In the student activities program, government required individuals to give money to it, but did not engage in any expression or in the creation of any message of its own. ${ }^{299}$ The essential features of unions that warrant the germaneness

460 ("[T]he public purpose of creating diversity in the marketplace of ideas justifies using public resources to pursue it.").

295. See Southworth, 529 U.S. at 233.

296. See id. at 232 ("It is not for the Court to say what is or is not germane to the ideas to be pursued in an institution of higher learning.").

297. See id. (stating that the University seeks to encourage discussion of "vast, unexplored bounds" and to stimulate the universe of speech and ideas); id. at 242 (Souter, J., concurring in the judgment) ("No one disputes the University's assertion that some educational value is derived from the activities supported by the fee ...."); Bezanson \& Buss, supra note 11, at 1427 (arguing that the Court's failure to set a standard of germaneness stems from the breadth of the university's mission).

298. See supra notes 56-76 and accompanying text.

299. See Southworth, 529 U.S. at 229 (emphasizing that the University had disclaimed any funded speech as its own); id. at 240 (Souter, J., concurring in the judgment) (emphasizing that students funded only the distributing agency having no social, political, or ideological character and itself engaging in no expression of any distinct message). 
test - the representative relationship and the existence of a common cause between the funders and the funded entity - are entirely absent.

The larger defect is the majority's emphasis on viewpoint neutrality in the funding programs. This requirement rests on the notion that an individual should not object to having her money support an expressive program as long as she, or an organization to which she belongs or supports, has equal access to the resources of the program, the same access as the objectionable speakers have. ${ }^{300}$ The problem is that the Court never explains at what point a funding program becomes viewpoint-discriminatory. That is, the opinion does not explain whether the funding program must be viewpointdiscriminatory on its face or in its actual application and operation. This ambiguous standard is either meaningless or results in the elimination of university activities funding programs.

On one hand, it might be enough that the program's rules and regulations afford competing speakers equal access to the funds and that any discretionary decisions about granting requests for funds must be based on specific, objective, neutral criteria. Perhaps a program that facially provides funding to all requesting organizations, regardless of viewpoint, satisfies the objector's right. Perhaps the objecting payer's right to challenge the program will be triggered only if the program, on its face and in its express regulations, excludes certain speakers or certain viewpoints. ${ }^{301}$ But this amounts to no protection at all, because a program could immunize itself from objecting-payer attack by simply adopting viewpoint-neutral terms and rules, without regard to how the fund actually is administered. This cannot be the proper understanding, given the Court's stated goal of providing meaningful safeguards for student payers. ${ }^{302}$

Logically, then, a single viewpoint-discriminatory decision, even one made in disregard for the plain, viewpoint-neutral language of the program regulations, is sufficient to render the program viewpointdiscriminatory and to trigger the objector's right. Suppose that the

300. See id. at 233 ("Viewpoint neutrality is the justification for requiring the student to pay the fee in the first instance and for ensuring the integrity of the program's operation once the funds have been collected.").

301. Compare Southworth, 529 U.S. at 234 (stating that the parties concede that student activities fund is viewpoint neutral), with Rosenberger v. Rector \& Visitors of Univ. of Va., 515 U.S. 819, 825 (1995) (discussing a student activity fees program in which regulations explicitly exclude religious activities).

302. See Southworth, 529 U.S. at 229 ("[T]he objecting students may insist upon certain safeguards with respect to the expressive activities which they are required to support."). 
Federalist Society is denied funds to bring Kenneth Starr onto campus for a speech, an event that should be reimbursable under the program's regulations, while the Sierra Club and the International Socialist Organization both receive funds for similar speaker events. The funding program now arguably can be understood as viewpoint discriminatory, at least in this single decision. For the Court's standard to have any meaning, that must trigger the objector's right. Thus, a student should be able to return to court to argue that the funding program is not, in fact, viewpoint neutral and that she is entitled to a refund of that portion of her fees that went to objectionable organizations such as the Sierra Club or International Socialist Organization. On this understanding, the Court's model blew open the courthouse doors for an objecting payer to challenge the entire administration of a student activities fee program on the basis of that single, improper funding decision.

The question of disagreement with the funded message as a prerequisite to bringing an objector's claim also looms. The Southworth majority mentioned that the plaintiffs objected to funding particular organizations and sought refunds of the portions of their fees that went to eighteen specified groups with which they disagreed. ${ }^{303}$ But the Court did not explain how the issue of disagreement determines the scope of the objector's right. This further muddies the Court's standard, because disagreement with the funded message should be irrelevant to the existence of a compelled speech violation. ${ }^{304}$

Assuming a single viewpoint-discriminatory denial of funds to one group, may an objecting student opt-out from providing funds only to those organizations with which she disagrees? Or may she optout of funding any student group, regardless of its message and her disagreement with that message? Moreover, must the objecting student be sympathetic to the group that was denied funding in order for her right to be triggered? Or is it enough for a student to argue that simply because some student organization was denied funding in a viewpoint-discriminatory fashion in a particular instance-regardless of the group and regardless of whether her beliefs are consistent with those of the group - she now may object to being required to fund some or all groups?

303. See id, at 231 ("It infringes on the speech and beliefs of the individual to be required, by this mandatory student activity fee program, to pay subsidies for the objectionable speech of others ...."); Southworth v. Grebe, 151 F.3d 717, 720-21 (7th Cir. 1998) (naming the objectionable organizations and describing their activities).

304. See supra notes 203-215 and accompanying text. 
Return to the unfunded Federalist Society event. Who may challenge this nonviewpoint-neutral programs: those students who are active members of the Federalist Society (and who actually were denied access), those students who are sympathetic to the Federalist Society, or all students who simply object to funding other private speech and speakers? And for what payments are they entitled to refunds or opt-outs - payments to groups arguably on the other side of the political spectrum (such as the Sierra Club) that received funds and whose messages the payer finds objectionable, or all groups that received funds through the program?

These questions all remain open after Southworth and nothing in the Supreme Court's opinion indicates how they should be resolved. The answers determine how wide the Court's opinion opens the gates to objector's claims. But regardless of the outcome in Southworth itself, the doors have been opened to a broad range of objecting payer challenges to the operation of university student activities funds. And it may be that the Court itself created a standard that could be "so disruptive and expensive that the program to support extracurricular speech would be ineffective," despite the Court's stated desire not to "put the program at risk." 305

Justice Souter criticized the majority for creating a new, but entirely undefined, category of free speech interests. ${ }^{306}$ The interest exists in a twilight zone. It is not government speaking with the funds collected from its constituents, to which no objector's right attaches. ${ }^{307}$ Nor, according to the Court, is the program a public forum. ${ }^{308}$ This "speaker" appears to be the funding program itself, although the program neither forms nor presents its own message. The Court never explains the origins or nature of this speaker. But it nevertheless recognizes a payer's right not to fund it, in some unexplained or undefined circumstances involving some unexplained or undefined group of plaintiffs, if the program does not speak in a viewpointneutral manner.

305. Southworth, 529 U.S. at 232.

306. See id. at 236 (Souter, J., concurring in the judgment) (stating that the majority recognized "a new category of First Amendment interests and a new standard of viewpoint neutrality protection").

307. See id. at 234-35 (emphasizing that the University is not speaking, but explaining the different standard that would prevail if it were); see also supra notes 113-152 and accompanying text.

308. See Southworth, 529 U.S. at 230. 


\section{OBJecting PAYERS' Rights IN THE PUBlic Forum}

There should be no doubt that the outcome in Southworth was correct. But the Court's reasoning is problematic, establishing an unexplained, undefined, and unworkable standard with the potential to undermine all student activities funds. This problematic reasoning leaves open the possibility that similar objectors could prevail on future claims, simply by showing viewpoint discrimination in the actual administration of the program. We suggest a different basis for rejecting such claims, using reasoning that eliminates the possibility of future challenges to student activity programs and precludes similar objector's challenges to expressive places and programs outside the university community.

\section{A. Student Activities Funds as Public Forums}

\section{Southworth Reconsidered}

The Supreme Court erroneously rejected the notion that the University of Wisconsin's student activities fund was a public forum. ${ }^{309}$ Rather, the Court's analysis should have proceeded from the starting point that the program is indeed a limited public forum, dedicated to providing resources with which student organizations may engage in expression on a range of political and ideological subject matters and viewpoints. Three arguments lead to this point.

The first argument follows a fortiori from Rosenberger v. Rector $\&$ Visitors of University of Virginia. ${ }^{310}$ The free speech aspect of Rosenberger rested on two distinct, but related, grounds. First, a public university's student activities fund is a metaphysical public forum that must be treated in the same way as a physical forum. ${ }^{311}$ Second, the metaphysical public forum of the student activities fund is not to be

309. See id. ("[T]he student activities fund is not a public forum in the traditional sense of the term ...."); see also Bezanson \& Buss, supra note 11, at 1424 ("[T] he Court's opinion seems anxious ... to avoid characterizing the Wisconsin student activities fund as a public forum.").

310. 515 U.S. 819 (1995).

311. See id. at 830 ("The SAF is a forum more in a metaphysical than in a spatial or geographic sense, but the same principles are applicable.”); Bezanson \& Buss, supra note 11 , at 1406 (arguing that public forums include not only physical spaces but metaphysical and metaphorical realms that can be the locus of individual speech opportunity); Gey, supra note 12, at 1563 (discussing Rosenberger as one of the first cases to show how public forum analysis can be used in cases involving more than the traditional context of parks and sidewalks); see also Bezanson \& Buss, supra note 11, at 1407 ("Rosenberger has now become the standard bearer for one of two poles in the Court's government speech jurisprudence," the pole in which government creates a forum for individual speech). 
operated in a viewpoint-discriminatory manner in determining which speakers should have access to the forum. ${ }^{312}$ The Court emphasized the special problem of viewpoint discrimination in the public forum, of government targeting speech because of the particular views taken by the speaker on an otherwise permissible subject matter, resulting in a more blatant and egregious form of impermissible content discrimination. ${ }^{313}$ Viewpoint-discriminatory laws, the Rosenberger Court seemed to suggest, are per se unconstitutional. ${ }^{314}$

The Southworth Court's fundamental error is that it seized on the second element of Rosenberger, the import of viewpoint neutrality, but ignored the first. The idea that a university student activities fund should be understood as a neutral forum for expression is not new. ${ }^{315}$ But the point assumes particular import after Rosenberger, where the

312. See Rosenberger, 515 U.S. at 831 (finding a free speech violation in the program's decisions, because the "prohibited perspective, not the general subject matter, resulted in the refusal" to fund speech "for the subjects discussed were otherwise within the approved category of publications"); Frederick Schauer, Principles, Institutions, and the First Amendment, 112 HARV. L. REv. 84, 105 (1998) (discussing the increasing importance of viewpoint discrimination in government enterprise cases).

313. See Rosenberger, 515 U.S. at 829; see also Martin H. Redish \& Gary Lippman, Freedom of Expression and the Civic Republican Revival in Constitutional Theory: The Ominous Implications, 79 CAL. L. REV. 267, 282 (1991) ("[A]t least in its theoretically pure state, the principle disallowing viewpoint regulation stands as the cornerstone of our democratic theory."); Schauer, supra note 312, at 105 (describing the distinction between subject matter and viewpoint discrimination as one of the important advances of recent free speech doctrine); Geoffrey R. Stone, Comment, Anti-Pornography Legislation as ViewpointDiscrimination, 9 HARV. J.L. \& PUB. POL'Y 461, 464 (1986) ("[G]overnment may not restrict speech because it disapproves of a particular message. In a democratic society, it is for the people and not the government to decide what ideas are 'good' or 'bad."'); Susan H. Williams, Content Discrimination and the First Amendment, 139 U. PA. L. REV. 615, 655 (1991) (describing viewpoint discrimination as the "most biased end" of a continuum of content discrimination).

314. See Rosenberger, 515 U.S. at 829; see also Stone, supra note 313 , at 475 (" $[\mathrm{A}]$ lthough the Court has never expressly held that such restrictions are per se unconstitutional, one might fairly read that lesson into the actual record of the Court's decisions."). But see Schauer, supra note 312 , at 105 ("[I]t is hardly clear that the line between viewpoint and other forms of content discrimination can be sustained, except possibly in extreme cases.").

315. See Cantor, supra note 11, at 48 (arguing that, "so long as funds are available on an equivalent basis to any student group satisfying neutral criteria," a forum for expression had been created); Greene, supra note 17, at 14 (arguing that the pool of money consisting of the student fees is correctly characterized as a viewpoint-neutral and subject matter-neutral forum); see also Southworth v. Grebe, 157 F.3d 1124, 1129 (7th Cir. 1998) (Wood, D., J., dissenting from denial of rehearing en banc) (arguing that the fees at the University of Wisconsin fund a neutral public forum). 
Court explicitly and unequivocally applied a public forum understanding to this very type of student activities fund. ${ }^{316}$

The Court's failure to grasp this first point is particularly surprising because in Rosenberger, while recognizing the student activities fund as a public forum, the Court expressly noted that the issue of a paying student's right not to contribute to that forum remained an open question. ${ }^{317}$ Rosenberger explicitly anticipated Southworth, the failure to follow the precise earlier reasoning on the public forum point is inexplicable. Moreover, two years prior to Southworth, all nine Justices expressed their understanding that Rosenberger was a case in which government had created a limited public forum through the student activities fund. ${ }^{318}$ Most importantly, the program in Southworth was materially identical to the program in Rosenberger. In both, the university collected fees, placed the money in a central fund controlled and administered by the student government, and distributed grants to qualifying student organizations to reimburse expenditures incurred for expressive activities. ${ }^{319}$

The Rosenberger Court described the student activities fund as a "forum more in a metaphysical than in a spatial or geographic sense," but subject to the same principles as a physical public forum. ${ }^{320}$ But the Southworth Court stated that the materially identical student activities fund "is not a public forum in the traditional sense of the term." ${ }^{321}$ The only way to reconcile the cases on this point is to recognize that the student activities fund in Southworth, like the fund in Rosenberger, is a limited metaphysical public forum, governed by ordinary public forum principles. ${ }^{322}$

316. See Gey, supra note 12, at 1563 (arguing that Rosenbergeropened the door to the use of a broader understanding of public forum analysis, "far removed from the traditional context of parks and sidewalks").

317. See Rosenberger, 515 U.S. at 840 ("[W]e do not have before us the question whether an objecting student has the First Amendment right to demand a pro rata return to the extent the fee is expended for speech to which he or she does not subscribe."); see also id. at 851 (O'Connor, J., concurring). ("I note the possibility that the student fee is susceptible to a Free Speech Clause challenge by an objecting student that she should not be compelled to pay for speech with which she disagrees.").

318. See Nat'l Endowment for the Arts v. Finley, 524 U.S. 569, 586 (1998) (O'Connor, joined by Rehnquist, C.J., and Stevens, Kennedy, Ginsburg, and Breyer, JJ.); id. at 598-99 (Scalia, J., joined by Thomas, J., concurring in the judgment); id. at 615 \& n.10 (Souter, J., dissenting).

319. Compare Bd. of Regents of the Univ. of Wis. Sys. v. Southworth, 529 U.S. 217, 221-24 (2000), with Rosenberger, 515 U.S. at 823-27.

320. See Rosenberger, 515 U.S. at 830.

321. See Southworth, 529 U.S. at 230.

322. See Bezanson \& Buss, supra note 11, at 1424 (stating that the student activities fund "looked a lot like a public forum"); Greene, supra note 17, at 14 ("It is the open forum 
The second argument establishes the fund as a public forum by analogy. Imagine that, rather than collecting student fees and placing the moneys in a fund to be distributed to student organizations, the University uses the funds to build, maintain, and staff a physical forum - an on-campus park or stage or auditorium - at which these student organizations' expressive activities occur. Collected funds are used to build and maintain the physical structure, purchase sound and light systems for speakers' use, and pay for and provide security, maintenance, and cleanup after events. The student government administers the location, establishing objective, viewpoint-neutral rules as to which student organizations can have access to the park or stage and for what types of expressive activities at what times. In other words, imagine that the university collects and spends student fees to establish a physical public forum and to provide student organizations with access to that physical forum for expressive activities. ${ }^{323}$

In both situations, the university uses mandatory student fees to provide a subsidy that enables private speakers to present and make heard their messages. ${ }^{324}$ With the physical forum, the university provides a physical resource and associated services for the speaker's use; with the funding forum, the university provides financial resources for that speaker's use. Given Rosenberger's insistence that the same principles apply to physical and metaphysical forums, government's use of funds to provide a physical place for private expression is no different for public-forum and compelled-expression analysis than the use of funds to provide a monetary subsidy for private expression. Using mandatory student fees to do either must be understood as using those fees to establish and operate a public forum on campus. ${ }^{325}$

that is funded ...."); see also Southworth v. Grebe, 157 F.3d 1124, 1129 (7th Cir. 1998) (Wood, D., J., dissenting from denial of rehearing en banc) ("Here, both the ASM and the University are doing nothing more than creating the forum for the expression of other people's views.').

323. See Southworth v. Grebe, 157 F.3d 1124, 1129 (7th Cir. 1998) (Wood, D., J., dissenting from denial of rehearing en banc) ("It is the same as if they simply built a large auditorium and held it open for everyone."); see also Greene, supra note 17, at 14 ("We can therefore analogize to other public forums funded by many people-a public park, a municipal auditorium, a public library, a public museum.").

324. See Kamenshine, supra note 23 , at 110 (arguing that the provision of a physical forum for speech is a form of government subsidy); see also Rust v. Sullivan, 500 U.S. 173, 200 (1991) (stating that the provision of access to government-owned property is a government subsidy).

325. See Gey, supra note 12, at 1603 (arguing for the need to "take Justice Kennedy's notion of a 'metaphysical' public forum seriously" and to apply forum analysis to subsidy cases as well as physical-property forum disputes). 
The third argument adopts a modified analysis of the public forum. According to Professor Gey, public forum analysis should consider "whether expressive activity would tend to interfere in a significant way with the government's own activities in that forum., $\mathrm{He}$ argues that any place or program "specifically used for the communication of information and ideas," is a forum; unless government establishes a strong likelihood of significant interference with that instrumentality from expression, the forum must be deemed public, and expressive access permitted, subject only to narrow, neutral time, place, and manner restrictions. ${ }^{327}$

Professor Gey extends this analysis to subsidy programs, such as in Rosenberger, specifically created for the communication of information and ideas. Such a funding program is an instrumentality of communication because it "facilitates the dissemination of information or ideas," the equivalent of Justice Kennedy's metaphysical public forum. ${ }^{328}$ The student activities fund at the University of Wisconsin also is an instrumentality of communication, and therefore a public forum, in that it expressly provides funds from the public university to enable and facilitate private expression and the dissemination of information and ideas by private student speakers to the university community.

The issue in Southworth thus should have been whether an individual payer may object to having the government use her portion of mandatory fees to create, maintain, and administer a public forum where the payer objects to, disagrees with, or does not wish to support some particular speaker having access to the forum. Justice Souter's

326. See Gey, supra note 12, at 1576; id. at 1570 (stating the test as whether "granting members of the public a right to free expression would significantly interfere with the government's own uses of public property"); see also Int'l Soc'y of Krishna Consciousness, Inc. v. Lee, 505 U.S. 672, 698 (1992) (Kennedy, J., concurring) (arguing that if expressive activity would be appropriate and compatible with the ordinary uses of property, the property is a public forum); BAKER, supra note 153, at 163 ("The government cannot restrict the use of government facilities in a manner that prohibits substantively valued first amendment conduct unless the conduct interferes with the constitutionally permissible purposes to which the government has dedicated the space or facilities.").

327. See Gey, supra note 12, at 1576 (quoting U.S. Postal Serv. v. Council of Green's Civic Ass'ns, 453 U.S. 114, 137 (1981) (Brennan, J., concurring in the judgment)); see also BAKER, supra note 153, at 170-71 ("[W]hen regulations that restrict the expressive use of public resources are not necessary to further dedicated uses, they should be understood as withdrawing those resources from expressive uses, and, therefore, as abridgements of people's freedom.").

328. See Gey, supra note 12, at 1604 ("An instrumentality of communication would therefore be equivalent to what Justice Kennedy's Rosenberger opinion termed a 'metaphysical' public forum."). 
concurring opinion hints at this understanding, emphasizing that the fees went only to the governmental distributing agency and only indirectly funded the jumble of other speakers' messages. ${ }^{329}$ But neither he nor the majority frames the issue specifically in public forum terms. ${ }^{330}$

A public forum understanding carries the analysis outside the university setting. Public universities are uniquely committed to the free exchange of ideas. ${ }^{331}$ But government at large establishes and maintains public forums similarly dedicated to the free exchange of ideas, to broadening public discourse, and to providing people an opportunity to speak and to be heard. ${ }^{332}$ The public forum doctrine finds its origins and its primary application in the community at large; after all, the quintessential public forums are the streets, sidewalks, parks, and village square, those places that "time out of mind, have been used for purposes of assembly, communicating thoughts between citizens, and discussing public questions.", ${ }^{933}$ Municipal governments spend public funds to maintain these quintessential traditional public forums and to provide police and fire services, security, crowd control, sanitation services, and sound amplification equipment so private groups may hold parades and rallies in public spaces.

Moreover, governments at all levels and in all communities may establish expressive subsidy programs that, like the student activities funds in Southworth and Rosenberger, function as instrumentalities of private dissemination of information and ideas. Consider the National Endowment for the Arts (NEA), which provides public grants to support the work of deserving artists. ${ }^{334}$ Under Professor Gey's

329. See Bd. of Regents of the Univ. of Wis. Sys. v. Southworth, 529 U.S. 217, 239-40 (2000) (Souter, J., concurring in the judgment).

330. See Bezanson \& Buss, supra note 11, at 1424 (arguing that the majority in Southworth wanted to rely on public forum analysis without calling the student activities fund a public forum).

331. See Southworth, 529 U.S. at 233 ("The University may determine that its mission is well served if students have the means to engage in dynamic discussions of philosophical, religious, scientific, social, and political subjects in their extracurricular campus life outside the lecture hall."); Calvert, supra note 167, at 58 (emphasizing the import of the marketplace of ideas in the unique setting of academia); Jacobs, supra note 11, at 443 (emphasizing the “"vast unexplored bounds' of the speech public universities seek to encourage").

332. See supra notes 179-186 and accompanying text.

333. See Int'l Soc'y of Krishna Consciousness, Inc. v. Lee, 505 U.S. 672, 679 (1992) (quoting Hague v. Comm. Indus. Org., 307 U.S. 496, 515-16 (1939)); Perry Educ. Ass'n v. Perry Local Educators' Ass'n, 460 U.S. 37, 45 (1983); SMOLLA, supra note 153, at 208; see also Gey, supra note 12, at 1538 (arguing that the public forum doctrine derives from the basic mythology of the lone speaker standing on a soapbox on the street corner).

334. See Nat'l Endowment for the Arts v. Finley, 524 U.S. 569, 573 (1998) (describing the NEA's purpose as helping to create a climate encouraging freedom of thought, 
approach, the NEA is an instrumentality of communication dedicated to providing government funds for private artistic expression that should be treated as a public forum. ${ }^{335}$ Government may establish a program such as the NEA as a limited public forum, dedicated only to art or artistic expression, but government cannot limit the program to funding only decent art (as it did in Finley), which directs a preferred subject matter (art) towards the government's favored viewpoint (decent and respectful). ${ }^{336}$

The Court and most commentators reject the notion that the NEA is a public forum akin to Rosenberger, relying on the fact that student activities funds are available generally to all qualifying organizations for purposes related to the mission of the university, while the NEA involves a competitive grant process, requiring government to make inherently content-based discretionary aesthetic and qualitative judgments about which expression to fund. ${ }^{337}$ But that distinction need not mean that an arts funding program cannot be analyzed as a public forum. Nor does the fact that discretionary, subjective, and qualitative decisions must be based on nonneutral standards such as artistic

imagination, and inquiry and to provide the material conditions facilitating the release of creative content).

335. See Gey, supra note 12, at 1604; id. at 1608-09 \& n.331 (arguing that requirement that NEA consider "decency and respect for ... diverse beliefs and values" runs afoul of the interference analysis of public forums, understanding the NEA as a traditional sphere of free expression); see also Cantor, supra note 11, at 36 (arguing for special status for any program that receives compelled funds in order to perform a "substantial 'service' function").

336. See Gey, supra note 12, at 1608-09; see also Finley, 524 U.S. at 613-14 (Souter, J., dissenting) (arguing that the NEA is a subsidy scheme created to encourage expression of a diversity of views from private speakers and decisions as to provision of those subsidies cannot be based on viewpoint popularity).

337. See Finley, 524 U.S. at 586 (stating that the competitive process involved in allocating grants, which was inherently content-based, distinguished the Endowment from the student activities fund, which involved general access and was a limited public forum); id. at 599 (Scalia, J., concurring in the judgment) ("[T]he government [in Rosenberger] had established a limited public forum-to which the NEA's granting of highly selective (if not highly discriminating) awards bears no resemblance."); see also Bezanson \& Buss, supra note 11 , at 1453 (arguing that the NEA's "selection process will reveal that some artistic communications are more valued than others and the decision that favors one artistic work over another will depend on what the artist 'expresses' in that work"); Lackland H. Bloom, Jr., NEA v. Finley: $A$ Decision in Search of a Rationale, 77 WASH U. L.Q. 1, 46 (1999) ("[T] he subsidy in [Rosenberger] was widely available while the one at issue in Finley was awarded on a competitive basis."). In a similar vein, Professor Schauer argued:

If access is mandatory, then the focus on content discrimination is redundant. But if access is not mandatory, then the existence (or not) of a public forum is superfluous. What is not superfluous is the question whether this is one of the government enterprises which may control for content or viewpoint, and as to this question public forum doctrine offers no assistance.

Schauer, supra note 312 , at 99 . 
excellence, artistic and cultural significance, or artistic worth. Government discretion in making these subjective decisions can be cabined by the "Professionalism Principle," a requirement that contentand value-based decisions about which art to fund be committed to the sound discretion of those people with the professional expertise in that area to judge the excellence and merit of art, applying established criteria applicable to the art world, removed from the prime political actors in government and from partisan political influence. ${ }^{338}$ Decisions as to which art to fund are neither neutral nor objective, but they may be made without regard to partisan political influences or to nonprofessional, nonartistic ideas. ${ }^{339}$

The NEA thus may be understood as a limited public forum for artistic expression, access to which is subject to professional judgments of artistic merit based on established and accepted criteria. There is no substantive difference between the NEA and the student activities fund. As Justice Souter suggested, if the latter also relied on competitive grants of a finite amount of funds to only a small percentage of student applicants, it still could be understood as a public forum. ${ }^{340}$

The point of this detour is to recognize a broader range of government funding programs in different political communities that function as instrumentalities of communication of information and ideas and that should be analyzed as public forums. This public forum status determines the proper analysis to apply to all compelled-payer challenges to such programs. It means the analysis that should have controlled in Southworth also controls in expressive subsidy programs outside the university setting.

338. See Smolla, supra note 153, at 195; Bezanson \& Buss, supra note 11 , at 1511 (arguing that expressive choices as to which speech to fund must be "made by professional and nonpolitical actors pursuant to an established and consistent process free of ideological or political considerations"); id. at 1466 ("By structuring the decision-making process in a way that moves the actual deciders outward from the prime political actors in government, the likelihood that artistic expression will be screened for its political acceptability is reduced.").

339. See SMOLla, supra note 153, at 195; Bezanson \& Buss, supra note 11, at 1466; Gey, supra note 12 , at 1608-09.

340. See Finley, 524 U.S. at 615 (Souter, J., dissenting) (arguing that, had the student activities fund in Rosenberger relied on competitive, merit-based allocations, "it is obvious beyond peradventure that the Court would not have come out differently"); see also Bezanson \& Buss, supra note 11, at 1452 (suggesting that a strong public forum dimension is present in an arts funding program if one assumes that government is creating a speaking opportunity for individual members of the public). 


\section{Objector's Rights in the Public Forum}

Having reformulated Southworth as an objecting payer's challenge to compelled funding of a public forum, the Court should have rejected the plaintiffs' claims. In collecting mandatory fees for the purpose of creating that public forum, the university acts as an honest agent in support of free speech, enabling private speakers to present their messages and allowing those messages to be heard. ${ }^{341}$ It would be a "deep misunderstanding" of the compelled speech doctrine to require that an objecting payer be able to opt out of supporting a public forum, which essentially would permit the rights of objectors to trump the rights of speakers making use of the forum. ${ }^{342}$

Rather, the payer who objects to the message being presented in the public forum stands in the same position as anyone who objects to the message being presented in the forum: neither has a right to have that speech halted or burdened because it offends her and neither has a right to veto speech in the public forum. ${ }^{343}$ The burden on both the objecting listener and the objecting funder is to avert their eyes in order to avoid the offending message. ${ }^{344}$ The objecting payer also may exercise her right to protest or speak out against those using the forum, particularly by gaining her own access to the forum and its resources in order to engage in counterspeech.

The objecting payer may not force government to constrict (or ultimately close) a public forum by burdening government's ability to collect and use community funds to operate it. Requiring government

341. See supra notes 179-186 and accompanying text.

342. See Greene, supra note 17 , at 14 .

343. See Forsyth County v. Nationalist Movement, 505 U.S. 123, 134-35 (1992) (holding that speech cannot be financially burdened, punished, or banned simply because it might offend a hostile listener); Cohen v. California, 403 U.S. 15, 21 (1971) ("The ability of government, consonant with the Constitution, to shut off discourse solely to protect others from hearing it ... would effectively empower a majority to silence dissidents simply as a matter of personal predilections."); Terminiello v. City of Chicago, 337 U.S. 1, 6 (1949) (overturning conviction under statute prohibiting speech that stirred people to anger or invited public dispute); see also Bloom, supra note 337, at 38 ("To the extent that indecent art sends a message or expresses a point of view that deeply offends some significant segment of the public, this type of harm is simply a legitimate cost of freedom of speech that the offended viewers must bear."); Gey, supra note 12, at 1586 ("[T] he principle of unrestricted public speech is unmediated by the fact that the expression will be heard or seen by unwilling listeners or viewers . . . ."); Geoffrey R. Stone, Content Regulation and the First Amendment, 25 WM. \& MARY L. REV. 189, 215-16 (1983) ("The Court's reluctance to accept the "heckler's veto,' and its refusal to permit one group of citizens effectively to 'censor' the expression of others because they dislike . . their ideas, seems well-grounded in the central precepts of the first amendment.").

344. See Cohen, 403 U.S. at 21. 
to refund moneys supporting the forum whenever an objectionable speaker uses that forum decreases the amount of money available to operate the forum and increases the administrative hassles involved in operating it, as government attempts to determine which payers object to which speakers and to grant pro rata opt-outs or refunds accordingly. ${ }^{345}$ This is true for the funding forum at issue in Southworth, for our hypothetical campus auditorium, and for all physical and metaphysical public forums in all political communities.

The Southworth Court's requirement of viewpoint neutrality as a structural safeguard is incoherent under a public forum understanding. If a public forum, whether physical or metaphysical, is administered in a viewpoint-discriminatory manner, it does not cease to be a public forum. To be sure, it is a viewpoint-discriminatory public forum, an unconstitutionally administered public forum, subject to challenge by any speaker denied or burdened in her access on the basis of her message or point of view. ${ }^{346}$ However, it remains a public forum, regardless of its viewpoint-discriminatory administration. From the payer's standpoint, lack of viewpoint neutrality in the operation of the forum cannot transform the compulsion to fund the government's management of the forum into a compulsion to fund directly the private speech that occurs there.

The viewpoint-neutrality rule becomes especially problematic under a public forum understanding. That logically demands that a single viewpoint-discriminatory denial of access to the forum to one speaker open the floodgates for objector's claims from every payer who does not wish to fund the speech of some or all speakers and

345. See Bd. of Regents of the Univ. of Wis. Sys. v. Southworth, 529 U.S. 217,232 (2000) (holding that establishing a refund system for the student activities fund "could be so disruptive and expensive that the program to support extracurricular speech would be ineffective"); Bezanson \& Buss, supra note 11, at 1427 ("The $A b o o d$ precedent requires a remedial means that is unworkable because any system requiring optional fees or a way for students to opt out from paying for specified activities would be disruptive and expensive and thus ineffective."); Cantor, supra note 11, at 26 (arguing that "[s]erious administrative tangles would inevitably result" from according a broad freedom of conscience a high constitutional status against government expenditures); see also supra notes 144-147 and accompanying text.

346. See Ark. Educ. Television Comm'n v. Forbes, 523 U.S. 666, 669 (1998) (involving an action brought by a candidate excluded from government-sponsored debate); Rosenberger v. Rector \& Visitors of Univ. of Va., 515 U.S. 819, 825-26 (1995) (involving an action brought by a student organization dedicated to publishing campus newspaper and denied funding from student activities fund); Nationalist Movement, 505 U.S. at 127 (involving an action brought by an organization seeking to hold demonstration and rally on courthouse steps). 
organizations otherwise entitled to access to that public forum. ${ }^{347}$ That is, of course, in addition to the First Amendment claim that the denied speaker may assert to gain access to the forum. Faced with such a multitude of challenges to the operation of the fund-both from those who want access to the forum and from those who wish not to provide money to it - the university likely will close the forum, discontinue the funding program, resulting in no voices being heard ${ }^{348}$ This is precisely what the Southworth Court was trying to avoid when it asserted that the "First Amendment does not require the University to put the program at risk.",349

The reliance on viewpoint neutrality in evaluating objecting payers' rights produces the perverse result of an overall decrease in the amount of speech, contrary to the very purpose of establishing public forums, which is to increase the sum total of available expression in the marketplace. ${ }^{330}$ If government makes a single improper viewpointdiscriminatory denial of access, it now must refund some portion of the collected funds to any objecting payer or payers; this decreases the amount of money available to operate the forum, thereby reducing the size and viability of the forum and the amount of speech it can accommodate. By contrast, the ordinary remedy where a speaker unconstitutionally is denied access to a public forum is to require government to admit that speaker to the forum; this broadens access and increases the sum total of expression facilitated by the forum and available in the marketplace. ${ }^{351}$

The reliance on viewpoint neutrality as a structural safeguard appears to rest on the notion that the objecting payer has no claim as long as she and her organization have equal access to the student activities fund for their own speech. ${ }^{352}$ Perhaps the Court's intention was to create an alternate remedy for the denied speaker-she may request access or she may request a refund. However, access should be the only remedy for a speaker denied access to a public forum; this remedies the constitutional violation while furthering the goal of

347. See supra notes $300-308$ and accompanying text.

348. Cf. Forbes, 523 U.S. at 681 (suggesting that, faced with a choice between an unwieldy forum and First Amendment liability, government might choose to present no voices at all).

349. Southworth, 529 U.S. at 232.

350. See supra notes 179-186 and accompanying text.

351. See supra notes 169-172 and accompanying text.

352. See Southworth, 529 U.S. at 233 (stating that a university supports extracurricular expression from its students through compelled fees in the interest of open discussion in a viewpoint neutral manner and that same viewpoint neutrality ensures the integrity of the program's operation once the funds have been collected). 
disseminating the greatest amount of speech. The remedy should not be a refund of fees paid to maintain the forum, having the opposite effect and potentially endangering the existence and administration of the forum itself.

\section{B. Application of the Compelled-Expression Doctrine to Public Forums}

We have recognized that the student activities fund in Southworth is a public forum and that objector's claims against funding this, and other, public forums must fail. We also have recognized that the protections imposed by the Southworth Court are unworkable on this understanding of the university's student activities fund. The next question is why the right not to be compelled by government to provide financial support for objectionable private speech does not extend to government-compelled financial support for the public forum in or through which that objectionable private speech will occur.

Under the analytical model for compelled expression established here, an objecting payer's free speech right is triggered if, and only if, she is compelled by the government to pay fees directly to a private speaker and that speaker uses those payments for expressive purposes. The focus of the inquiry is narrow. We look at where the money goes immediately after it leaves the payer's hands and for what purpose, whether the funds are paid directly by the funder to a private speaker for something that is expressive or whether paid by the funder to some other entity for something that is not expressive. ${ }^{353}$ This three-part model best explains why the objectors' claims properly failed in Southworth and why any challenges to the compelled funding of public forums, physical or metaphysical, in the university or in the community at large, similarly must fail.

First, and foremost, is the basic structural point of public forums. No speech is, in fact, funded with any fees charged and collected by the government in maintaining a public forum. Only the forum is funded ${ }^{354}$ that is, only the physical place and the services associated with that place or only the pool of money. That physical place and pool of money are, in and of themselves, nonexpressive things and no free speech rights attach to compelled payments for nonexpressive

353. See supra Part III.

354. See Greene, supra note 17, at 14 ("It is the open forum that is funded ...."); see also Southworth v. Grebe, 157 F.3d 1124, 1129 (7th Cir. 1998) (Wood, D., J., dissenting from denial of rehearing en banc) (" $[\mathrm{B}]$ oth the ASM and the University are doing nothing more than creating the forum for the expression of other people's views."). 
things. ${ }^{355}$ The forum itself, distinct from any uses of that forum, is not expressive in nature. Establishing and maintaining the forum is not an intrinsically expressive act and the use of the funds to establish and maintain the forum is not an intrinsically expressive expenditure. This is the touchstone of the analysis.

Further, the immediate recipient of the funds in the public forum situation is the government, not the private speaker. Money moves from the compelled payer to the government, without any knowledge, thought, or notion, by payer or government, of the ultimate private speaker who later will use these funds or the product of these funds. The payer funds the governmental distributing agency. ${ }^{366}$ Payers have no right to object to payments that do not go directly to the private speaker, particularly when those funds go to government for nonexpressive expenditures. Any incursion on conscience resulting from expression that occurs in the forum, as a remote result of nonexpressive government expenditures on the public forum itself, must be understood as a necessary "concomitant of living in an organized society. ${ }^{335}$ This is particularly true of an organized society that is committed to the enhancement of free speech and public discourse. ${ }^{358}$

Consider the example of the on-campus auditorium or park paid for with collected mandatory student fees. Moneys compelled from the student payers go to the university and the student governmentthe relevant government entities - neither of which is a speaker. The university uses those funds to erect and maintain the building or physical space, to pay the costs of administering the space, and to pay for services associated with the use of the space, such as security and crowd control during events, sound systems, and maintenance. None of these expenditures is for speech; the physical place or structure is not expressive, nor is the campus police force that provides security and crowd control.

355. See supra notes $198-202$ and accompanying text.

356. See Southworth, 529 U.S. at 240 (Souter, J., concurring in the judgment) (arguing that payers fund only the governmental distributing agency, which itself engages in no expression).

357. See Cantor, supra note 11 , at 25.

358. See BAKER, supra note 153, at 170 (arguing that government must exhibit a level of concern for ensuring private speech and assembly in government-owned areas); SMOLLA, supra note 153, at 208-09 (arguing for a community's duty to provide public forums dedicated to free expression and the exchange of ideas); BeVier, supra note 169, at 101 ("The Enhancement model ... sometimes imposes affirmative duties on government to maximize the opportunities for expression."). 
In other words, the compelled payments are spent directly and immediately only on the nonexpressive place and associated services. The objector cannot be understood as paying for the speech that occurs in that physical forum and with the aid of those services, and she cannot be understood as giving anything to the speaker. ${ }^{359}$ The payer cannot challenge the portion of her funds paying the salary of a campus police officer-a nonexpressive actor engaging in nonexpressive activities - simply because that officer is assigned to provide security for a private expressive event in the public forum that presents a message with which the payer disagrees.

This analysis carries outside the university to physical forums in the community at large. ${ }^{360}$ When a municipal government uses dollars

359. See Greene, supra note 17, at 14 ("[M]any voices are then heard in the forum, none specifically attributable to any one citizen or citizens, none specifically fostered by any one citizen or citizens.").

360. We put to one side the question of whether a payer has standing to challenge the expenditure of her tax dollars and other mandatory payments in establishing and maintaining a public forum. See Massachusetts v. Mellon, 262 U.S. 447, 487-88 (1923) (rejecting standing of single taxpayer to enjoin operation of statute unless he can show that "he has sustained or is immediately in danger of sustaining some direct injury as the result of its enforcement, and not merely that he suffers in some indef inite way in common with people generally"). We note several points that render the standing point less than absolute and that justify proceeding to the First Amendment merits of an objecting taxpayer's challenge to the use of compelled payments to fund a physical public forum.

First, a public forum could be funded by compelled payments that do not qualify as taxes, such as assessments imposed on members of a particular industry, as in United Foods and Wileman Bros. That would be sufficient direct injury to confer standing on a payer Second, the rule against taxpayer standing is considerably more relaxed at the municipal level, suggesting that a municipal taxpayer more easily could establish standing to object to a local program designed to provide resources and a physical place to private speakers. See Mellon, 262 U.S. at 486 ("The interests of a taxpayer of a municipality in the application of its moneys is direct and immediate and the remedy by injunction to prevent their misuse is not inappropriate."). Third, and most importantly, taxpayer standing rules are different when the government expends funds in a manner that may violate the Establishment Clause of the First Amendment. As the court stated in Flast v. Cohen, 392 U.S. 83, 105-06 (1968):

[A] taxpayer will have standing consistent with Article III to invoke federal judicial power when he alleges that congressional action under the taxing and spending clause is in derogation of those constitutional provisions which operate to restrict the exercise of the taxing and spending power. The taxpayer's allegation in such cases would be that his tax money is being extracted and spent in violation of specific constitutional protections against such abuses of legislative power.

The Establishment Clause often is understood as a structural restraint on government power, preventing government from imposing on individuals certain religious messages, at least through the expenditure of public funds. See Carl H. Esbeck, The Establishment Clause as a Structural Restraint on Governmental Power, 84 lowA L. REV. 1, 4 (1998); see also id. at 5-6 (arguing that relaxed standing requirements under Establishment Clause support this structural understanding); Neal R. Feigenson, Political Standing and Governmental Endorsement of Religion: An Alternative to Current Establishment Clause Doctrine, 40 DEPAUL L. REv. 53, 64 (1990) (describing argument that by "expending tax 
collected from members of the community to provide police security, traffic and crowd control, and sanitation services for the Gay Pride Parade through the streets of the city, tax money is spent on police, traffic, and sanitation services, as well as on the general maintenance of streets themselves. Again, these are nonexpressive expenditures; neither paying to pave a street nor paying a police officer's salary is expressive. Importantly, these expenditures do not become expressive merely because the streets are used for offensive private speech or because the police officer protects those offensive speakers. Moreover, these are government expenditures, further removing them from objector's challenge.

The Supreme Court should have used this precise reasoning in rejecting the challenge to the student activities fund in Southworth. Under the primary portion of the University of Wisconsin program, which the Court upheld as constitutional, students paid their mandatory activities fee of $\$ 165$ to the University, which placed the money in one of several funds controlled and administered by the student government. ${ }^{361}$ The immediate recipients of the moneys are the relevant government bodies, the university and the student government, neither of which is acting as a speaker. ${ }^{362}$ The immediate use of the money is to establish and maintain the fund itself, the pot of money, a nonexpressive thing. The individual student funds only that nonexpressive pool of cash; she does not fund the private speakers who receive money or the private expression that ultimately occurs with the resources from that pot. ${ }^{363}$ The payer's free speech right is not triggered by compelled payment to government for nonexpressive uses.

revenues to assist religion, government effectively compels some people to support religion against the dictates of conscience'). The compelled speech doctrine arguably reads a similar structural restraint into the Free Speech Clause, prohibiting government from imposing certain private messages on individuals by requiring them to pay money to fund or support such messages. If so, then the same relaxed standing rules also might apply when a taxpayer objects to the expenditure of at least her portion of tax dollars to support private speech.

361. See supra notes 245-250 and accompanying text.

362. See Bd. of Regents of the Univ. of Wis. Sys. v. Southworth, 529 U.S. 217,229 (2000) ("The case we decide here, however, does not raise the issue of the government's right, or, to be more specific, the state-controlled University's right, to use its own funds to advance a particular message."); $i d$. at 240 (Souter, J., concurring in the judgment) (arguing that student activities fees fund only the distributing agency presenting no distinct expression or message). Under our analysis, of course, the objecting students could not challenge the University's use of compelled funds for its own expression. See supra notes 124-134 and accompanying text.

363. See Greene, supra note 17 , at 14 ("[M]any voices are then heard in the forum, none specifically attributable to any one citizen or citizens, none specifically fostered by any one citizen or citizens."); see also Southworth, 529 U.S. at 239-40 (Souter, J., concurring in 
We can illustrate the analysis further by comparing a situation in which the objector's right might be triggered: the secondary portion of the Wisconsin program in Southworth, in which a majority of the student body votes to award funds to a specific student organization. ${ }^{364}$ In this situation, the student in effect pays her compelled fees directly to a favored private organization, as determined by majority vote, and that organization immediately uses those fees for expression. ${ }^{365}$ Under our test, the objector's right is triggered. The student in this portion of the program is not funding the public forum; she is funding a specific, majority-determined expressive organization in the dissemination of its private (and perhaps, although not necessarily, objectionable) message. She is compelled by government to provide funds for the immediate benefit of a known speaker. This is what the compelled speech doctrine prevents; even under our analysis, the Court was correct in remanding for further inquiry into this aspect of the University of Wisconsin program.

Finally, we look outside the university to the NEA and similar expressive subsidy programs, properly understood as metaphysical public forums subject to cabined discretionary judgments under professionalism principles. ${ }^{366}$ An objecting payer's challenge to the moneys going to a particular offensive art project funded by an NEA grant would fail for the same reason a challenge to the primary student activities fund fails. The individual taxpayer gives money to the government, not to the artist. Tax or assessment dollars fund a central pool of money controlled and administered by the Endowment, the governmental distributing agency, not the individual artist's expression. Taxpayers are compelled to fund only that nonexpressive pot of money, not the ultimate expressive use of some portion of these resources by

the judgment) (arguing that the collected fees indirectly fund the jumble of other speakers' voices).

364. See Southworth, 529 U.S. at 224; see also supra note 249 and accompanying text.

365 . It is likely that the funds awarded to an organization via voter referendum do not go directly to the organization, but actually pass through the government first, which then passes the funds to the favored group. But the analysis is the same. When government collects compelled fees explicitly earmarked for a private speaker, it effectively orders payment from the compelled payer to that designated private organization. This is why the second prong of our model looks to whether funds are paid directly and immediately to, or for the express benefit of, a private speaker. See discussion supra Part III. Payment of funds for a designated speaker might be akin to a situation in which the government establishes and maintains a physical forum for the exclusive long-term use of one particular private speaker. See Kamenshine, supra note 135, at 1141.

366. See supra notes $334-340$ and accompanying text. We again put to one side whether a federal taxpayer lacks standing to challenge the expenditure of her tax dollars for such an expressive program as the NEA. See discussion supra note 360. 
the individual artist who receives an NEA grant and produces art with the aid of that grant. Once more, such nonexpressive expenditures by government cannot trigger an objecting payer's right.

\section{Other Explanations for the Denial of Objector's Rights}

This analytical model provides the most coherent and consistent explanation for why objecting payers cannot challenge the use of compelled payments to establish and maintain physical public forums and expressive subsidy programs understood as metaphysical public forums. Commentators have suggested other explanations, none satisfactory. The problem is that all ignore the public forum point and the fact that funding a public forum means funding a nonexpressive government program, rather than any private speech or speaker. These commentators rely instead on explanations that are inconsistent with compelled-expression principles, public forum principles, or both.

\section{Justice Souter}

Justice Souter's concurring opinion in Southworth suggests that he understood the outlines of the public forum nature of the student activities fund, even though he did not speak in public forum terms. ${ }^{367}$ $\mathrm{He}$ focused on two reasons for rejecting Southworth's free speech claim, which might be understood as providing a basis for rejecting all objections to funding public forums: (1) the attenuated, indirect connection between the funders and any objectionable message ultimately produced with moneys from the activities fund, ${ }^{368}$ and (2) the governmental purpose of broadening public discourse. ${ }^{369}$ These factors, Justice Souter argues, render the plaintiffs' claims weaker than the successful objectors' claims in Abood and Keller (as well as United Foods, which would be decided one year later). ${ }^{370}$

367. See Southworth, 529 U.S. at $239-40$ (Souter, J., concurring in the judgment) (describing the student activities fund as requiring payers to fund the distributing agency and to "indirectly fund[] the jumble of other speakers' messages").

368. See id. at 240 (Souter, J., concurring in the judgment); see also Bezanson \& Buss, supra note 11, at 1434 (" $[\mathrm{N}]$ o reasonable person, knowledgeable of the student fee system and its purposes, would attribute the views of any single group supported by the fees to individual students whose only connection with the group was their payment of a mandatory fee."); Cantor, supra note 11, at 20 ("Nor can the views of a university organization be fairly attributed to the individual students whose fees support the central organization and its funded beneficiaries."); Greene, supra note 17, at 14 ("[M]any voices are then heard in the forum, none specifically attributable to any one citizen or citizens, none specifically fostered by any one citizen or citizens.").

369. See Southworth, 529 U.S. at 240-41 (Souter, J., concurring in the judgment).

370. See id. at 242-43 (Souter, J., concurring in the judgment). 
Neither of these rationales, alone or in combination, sufficiently explains the rejection of the compelled-expression claim in Southworth. First, as previously argued, a close connection between funder and message should not be a constitutional necessity in the ordinary compelled funding case..$^{371}$ It certainly should not be an issue where the forum itself and its jumbled multitude of voices, rather than a specific private speaker, is funded.

Second, government-compelled direct support for private expression is impermissible even if supported by an important government interest. The state of West Virginia wanted to foster national unity by requiring the Pledge of Allegiance. ${ }^{372}$ The agencyshop laws in Abood and Lehnert were supported by concededly important government purposes of ensuring labor peace and enabling unions to avoid free riders. ${ }^{373}$ In United Foods, Congress sought, through the Mushroom Council, to pursue the goals of promoting and supporting the mushroom industry and providing information about mushrooms to consumers. ${ }^{374}$ In Hurley, the Gay, Lesbian and Bisexual Group sought access to the parade pursuant to the state's public accommodations law, a statute specifically designed to prevent and remedy invidious discrimination against identifiable, vulnerable minority groups. ${ }^{375}$ None of these government purposes-particularly the interests underlying the antidiscrimination law-seems less compelling than the interest in broadening public discourse, yet all were held insufficient to justify direct compelled utterance or support of political and ideological speech.

Even assuming that broadening public discourse is a uniquely important government purpose ${ }^{376}$ such purpose could not justify a true compulsion that an individual directly fund the speech of another private entity. Imagine that the government, concerned that the ACLU

371. See Kamenshine, supra note 23, at 116 (describing this as a "make-weight" in the Court's analysis); see also supra notes 216-227 and accompanying text.

372. See W. Va. State Bd. of Educ. v. Barnette, 319 U.S. 624, 640 (1943) (stating that there is no question or debate as to "[n]ational unity as an end which officials may foster").

373. See Lehnert v. Ferris Faculty Ass'n, 500 U.S. 507, 520-21 (1991); Abood v. Detroit Bd. of Educ., 431 U.S. 209, 224 (1977); see also Keller v. State Bar of Cal., 496 U.S. 1,12 (1990) (stating that the state's bar membership requirement was aimed at regulating the legal profession and at preventing free-riders from reaping benefits of their unique status as a lawyer licensed to practice in the state).

374. See United States v. United Foods, Inc., 533 U.S. 405, 408 (2001). (1995).

375. See Hurley v. Irish-Am. Gay, Lesbian \& Bisexual Group, Inc., 515 U.S. 557, 571

376. See Jacobs, supra note 11, at 446 (arguing in support of the "collective majority's power to compel its members to support the common purpose of adjusting the relative weights of the voices in the marketplace of ideas to promote more full dialogue and debate"). 
or the Rutherford Institute will be unable to get its message out, requires every adult citizen to donate $\$ 1000$ directly to each organization. The underlying interest is broadening and diversifying public debate, ensuring that those two speakers have the resources and ability to be heard in the marketplace, adjusting the relative weights of voices in the marketplace. Such a requirement almost certainly would and should violate the payers' free speech rights. ${ }^{377}$ The requirement that GLIB be permitted to march in the private parade arguably was supported by a government interest in broadening the discourse of the parade, ensuring that an additional, vulnerable minority voice would be presented and heard by the large crowd that would witness the event. But the Hurley Court emphatically rejected the imposition of such a burden on the private parade organizers. ${ }^{378}$

It is at best disputable whether government's interest in broadening and diversifying public discourse ever justifies compelled private expression. ${ }^{379}$ It certainly is disputable whether such an interest provides a greater justification for compelled expression than any of the interests the Court has rejected.

\section{Robert Kamenshine}

Professor Kamenshine offers an explanation containing two separate, but related points. First, he argues that most traditional public forums, such as streets, sidewalks, and parks, are "primarily designed, funded, and constructed to serve a non-communicative purpose, and are used only incidentally for First Amendment activity." ${ }^{380}$ Streets and sidewalks primarily are used for transportation and movement, the steps of the courthouse primarily are used for egress and ingress from the courthouse, parks primarily provide recreation, beauty, and open space. ${ }^{381}$ In compelling funding of such physical places (through mandatory taxes, fees, and assessments), government compels funding for primarily nonexpressive purposes

377. The compelled payment would be unconstitutional regardless of whether the individual agreed or disagreed with the organization that she was forced to fund. See Kamenshine, supra note 23, at 115 (arguing that it is hard to imagine that the Court would uphold a requirement that each person contribute to the political party of her choice). This illustrates why disagreement with the funded message is more a make-weight than a true element of compelled-expression analysis. See supra notes 203-215 and accompanying text.

378. See Hurley, 515 U.S. at 574-75.

379. See Redish \& Kaludis, supra note 44, at 1122.

380. Kamenshine, supra note 23, at 108.

381. See Int'l Soc'y of Krishna Consciousness, Inc. v. Lee, 505 U.S. 672, 696-97 (1992) (Kennedy, J., concurring in the judgment). 
and the objector's right is not implicated by the secondary expressive purposes or uses.

This argument is on the right track, but it does not go far enough. The issue is not whether the use of the forum is primarily or secondarily expressive. The issue is that the designated public forum in and of itself, distinct from the private use of that forum, is not expressive. ${ }^{382}$

Professor Kamenshine leaves an analytical gap between traditional public forums, those places that "immemorially time out of mind" have been preserved for expression (primarily or incidentally), ${ }^{383}$ and designated public forums, those places that government specifically and intentionally has established, opened, and maintained primarily for expressive purposes, by opening a nontraditional space for public discourse. ${ }^{384}$ However, access requirements are the same for traditional and designated public forums. ${ }^{385}$ It follows that such forums should be treated the same when considering whether an objecting payer may challenge the use of her compelled fees to establish and maintain either type of forum. This is particularly true given that traditional public forums, such as streets and parks, cannot alone satisfy individual free speech needs in a private society; this obligates

382. See supra notes $354-355$ and accompanying text.

383. See Ark. Educ. Television Comm'n v. Forbes, 523 U.S. 666, 677 (1998) ("Traditional public fora are defined by the objective characteristics of the property, such as whether, 'by long tradition or by government fiat,' the property has been 'devoted to assembly and debate."') (quoting Perry Educ. Ass'n v. Perry Local Educators' Ass'n, 460 U.S. 37, 45 (1983)); Int'l Soc'y of Krishna Consciousness, Inc., 505 U.S. at 679 (describing streets and parks as places that have traditionally been available for public expression, that have "immemorially been held in trust for the use of the public and, time out of mind, have been used for purposes of assembly, communicating thoughts between citizens, and discussing public questions"') (quoting Hague v. Comm. for Indus. Org., 307 U.S. 496, 515-516 (1939)); SMOLLA, supra note 153, at 208.

384. See Forbes, 523 U.S. at 677 ("“ [T] The Court has looked to the policy and practice of the government to ascertain whether it intended to designate a place not traditionally open to assembly and debate as a public forum."') (quoting Cornelius v. NAACP Legal Def. \& Educ. Fund, Inc., 473 U.S. 788, 802 (1985)); Int'l Soc'y of Krishna Consciousness, Inc., 505 U.S. at 678 (describing a designated public forum, either of limited or unlimited character, as property that the state has opened for expressive activity by all or part of the public); SMOLLA, supra note 153, at 210; Gey, supra note 12, at 1547; see also id. at 1570 (arguing for the elimination of the designated or limited public forum category in favor of consideration of whether the speech at issue is compatible with the typical usage of the government property).

385. See Int'l Soc'y of Krishna Consciousness, Inc., 505 U.S. at 678 (stating that regulation of a designated public forum property is subject to the same limitations as that governing a traditional public forum); SMOLLA, supra note 153, at 210 ("The same legal standards for regulating speech thus apply to Category I 'traditional' forums and Category II 'designated' forums."); Gey, supra note 12, at 1547 (“'OO]nce a court deems a non-traditional forum 'public,' the speaker is well on the way to gaining access to that forum."). 
government to create new forums, physical or otherwise, in order to fulfill its constitutional duty to provide sufficient opportunities for private expression. ${ }^{386}$

Under Professor Kamenshine's approach, an objecting payer arguably could prevail if she shows that the designated public forum funded by her compelled fees was intentionally opened by the government for the express, primary, or even sole purpose of supporting private speech. This makes expressive subsidy forums, such as the NEA or the university student activities fund, uniquely vulnerable to compelled-expression challenge, even if other forums, such as city sidewalks, are not.

Further, this would require different treatment of different designated forums, depending on the primary purpose behind the establishment of that physical space. For example, an objecting payer would be unable to challenge the use of her money where objectionable private speech occurs in a classroom used as an public forum after school hours. The primary use of the classroom (and the primary reason the government expends collected funds to maintain that classroom) is public education; the private expressive use is secondary and incidental. ${ }^{387}$ However, that same objecting payer would be able to challenge the use of a public auditorium that has been built, funded, and maintained primarily, specifically, and exclusively to provide a forum for private expression, such as theatrical productions. ${ }^{388}$ And that payer would be able to challenge funds going to any metaphysical forum, such as a student activities fund or the NEA, programs having no existence and no purpose outside of the

386. See BAKER, supra note 153, at 171 (arguing that in a location in which weather may prevent outdoor expressive activity, government cannot ban expressive activities in indoor locations); Bezanson \& Buss, supra note 11, at 1409 ("[T]he needs of individuals for free speech opportunities in a modern society have not been fully satisfied by the traditional public forum.").

387. See Good News Club, Inc. v. Milford Cent. Sch., 533 U.S. 98, 106 (2001) (assuming, based on stipulation, that school district established a limited public forum when it opened classrooms for after-hours uses for a range of expressive purposes).

388. Cf. Southeastern Promotions, Ltd. v. Conrad, 420 U.S. 546, 555 (1975) (holding that a municipal auditorium is a public forum designed for and dedicated to expressive activities); id. at 563 (Douglas, J., concurring in part and dissenting in part). Justice Douglas argued:

A municipal theater is no less a forum for the expression of ideas than is a public park, or a sidewalk; the forms of expression adopted in such a forum may be more expensive and more structured than those typically seen in our parks and streets, but they are surely no less entitled to the shelter of the First Amendment.

Id. (Douglas J., concurring in part and dissenting in part). 
government decision to create them in order to facilitate the dissemination of expression by providing funds to private speakers.

Professor Kamenshine's second point is that, "to the extent that the First Amendment itself compels free access to public fora for purposes of engaging expression, there is no basis for complaint by dissenting taxpayers. ${ }^{9389}$ This again creates different outcomes, depending on whether the objecting payer challenges a traditional or designated public forum.

This also permits an objecting payer to challenge government's decision to establish the designated forum in the first instance, that is, government's determination that the designated forum is necessary to fulfill the community's obligation to provide opportunities for expression. Government's primary purpose in establishing a subsidy program or other nontraditional public forum is to facilitate private expression, some of which might be objectionable to the individual payer. If an individual payer could establish that the designated forum is not, in fact, necessary to fulfill the community's expressive needsbecause, for example, the community has enough other forums to accommodate private expression - she could argue that the First Amendment does not, in fact, compel access to a particular place or program. Under Professor Kamenshine's rule, that forum becomes subject to challenge by an objecting payer on the ground that the First Amendment does not mandate it.

\section{Lackland Bloom}

Professor Bloom shadows the second Kamenshine point about government having no choice but to provide access. He suggests that a broad congressional interest in protecting taxpayer sensibilities may justify viewpoint discrimination in certain subsidy programs, such as the NEA. ${ }^{390}$ Professor Bloom defends the result in Finley, where the Court upheld the requirement that the NEA fund only works that reflect decency and respect for ordinary American values, arguing that the restriction serves the governmental interest in protecting taxpayer sensibilities by not forcing taxpayers to fund offensive art. ${ }^{391}$

389. See Kamenshine, supra note 23, at 108.

390. See Bloom, supra note 337 , at 37 .

391. See id. ("[T]he First Amendment should tolerate the decency and respect clause ... because the harm to the taxpayer from being forced to fund indecent and disrespectful art is a distinct and cognizable type of harm from which Congress should be able to provide protection."); id. at 39 (arguing that the "interest in not forcing taxpayers to financially support objectionable speech is a distinct and cognizable injury worthy of legal recognition 
He argues that this reasoning would not apply to the university student activities funds in Rosenberger and Southworth. In such broad-based, nondiscretionary subsidy programs, government has no choice but to fund a particular speaker; taxpayers simply must understand that government has no choice but to provide funds to a particular speaker. ${ }^{392} \mathrm{He}$ argues that

[a]llowing speakers to use a public forum is a type of subsidy, but because it is made available on a nondiscretionary basis, the taxpayer should understand that the Government is not using public funds to select and prefer an offensive assault on community norms; rather, it is simply playing host to all points of view. ${ }^{393}$

Although this understanding "may not wholly eliminate the indignity of being forced to subsidize offensive speech," it "should go a long way toward minimizing it."394

Professor Bloom's distinction between these two different subsidy programs fails once we recognize the NEA and other discretionary subsidy programs as public forums, instrumentalities specifically used for the communication and dissemination of information and ideas, albeit governed by somewhat different principles in making access decisions. ${ }^{395} \quad$ Professor Bloom's approach, like Professor Kamenshine's, impermissibly demands different rules for different types of public forums. This results in different analysis for different compelled speech claims, depending on the operational specifics of the particular forum. This similarly ignores the more basic point that

and respect"); id. ("In arts funding, the Government allocates the funds in a way that attempts to take account of taxpayer sensibilities.").

Professor Bloom disclaims the suggestion that recognition of this interest means "every disgruntled taxpayer has the right to complain about any disbursement of federal funds to promote a message or cause with which he disagrees." Id. at 39 . He argues that this interest in protecting taxpayer sensibilities is asserted not by the individual taxpayer, but by the majority through the legislative process, and that the doors are not open to every malcontent to bring the government to a halt. See id. But there is no reason for this limitation. If taxpayers have a First Amendment interest in not having objectionable art funded with government funds, there is no reason that the individual taxpayer may not assert that interest on her own. If there is an interest in sensibilities, liberty, and conscience to be protected through the legislature, there is no reason individuals should not be able to protect those same interests through the courts, at least assuming satisfaction of standing requirements. See discussion supra note 360 .

392. See Bloom, supra note 337 , at 46 .

393. Id.

394. See id; see also Bezanson \& Buss, supra note 11, at 1434 (arguing that no reasonable person, knowledgeable of the student fee system and its purpose, would attribute the views of any speaker to individual students whose only connection is a compelled payment).

395. See supra notes $334-340$ and accompanying text. 
payers fund only the nonexpressive government-controlled pool of money that constitutes the forum, not the private speakers, their private speech, or any assault that the private speech might impose on payers' sensibilities.

\section{Leslie Jacobs}

Professor Jacobs recognizes that the governmental purpose in creating the student activities fund is to create a forum specifically to support speech. ${ }^{396}$ She argues, as Justice Souter did, that the balance of interests changes precisely because government's purpose is to foster exposure to a wide range of views, promote fairness in the presentation of views, and protect disfavored speakers. ${ }^{397}$ The key is that the forum (i.e., the subsidy fund) and the speech that will occur with the aid of that fund are linked, that "where creating a public forum is the purpose, funding speech in the university context is not incidental to some other nonspeech objective. Funding speech is the objective."398

This distinguishes the student fees case from prior compelledexpression cases. In the union cases, government mandated membership in an organization designed to serve a primarily nonspeech collective function, with expressive activities only tangentially related to that purpose. ${ }^{399}$ Any speech by the union was incidental to the primary, nonexpressive purpose for which it collected dues; such speech was dispensable and there would be no harm to the union's central, nonexpressive function if it could not speak with compelled funds. ${ }^{400}$ By contrast, funding speech is the very purpose for compelling the student fees. Speech is indispensable and directly related to the central purpose of the university's program, which would

396. See Jacobs, supra note 11 , at 456 .

397. See id. at 470 (arguing that a university is justified in expending compelled fees to create a forum, because its purpose is to foster intellectual diversity linked to its educational mission and to promote fairness in the presentation of views to its students); id. at 456 ("[W]here the government creates and structures a public forum, its speech-conscious action may serve rather than thwart free speech clause values."); Jacobs, supra note 7, at 176 ("[C]reating a public forum to promote diverse expression should be viewed as a justification that can meet strict review."); see also Bd. of Regents of the Univ. of Wis. Sys. v. Southworth, 529 U.S. 217, 240-41 (2000) (Souter, J., concurring in the judgment) ("Southworth's objection has less force than it might otherwise carry because the challenged fees support a government program that aims to broaden public discourse.").

398. Jacobs, supra note 11 , at 444 (footnote omitted).

399. See id. at 443-44.

400. See id; see also Jacobs, supra note 7, at 174 ("[C]ontributions, even for speech, may be constitutional if germane to the (presumptively nonspeech) purpose for the compulsion."). 
be harmed if government could not use mandatory fees to fund speakers. In other words, the use of compelled payments is valid where speech is the main purpose of the compulsion, as in Southworth, but not where it is an incidental or tangential purpose of that compulsion.

One problem with this explanation is that two recent decisions turn it on its head. In Wileman Bros., the Court rejected the objecting compelled payer's claim precisely because any generic advertising funded by the mandatory assessments on tree-fruit growers was incidental to the broader nonexpressive purpose of the economic regulatory scheme. ${ }^{401}$ In United Foods, the Court accepted the objector's claim precisely because virtually all the funds collected were used for a single expressive purpose, generic advertising, and the organization had no nonexpressive purpose independent of the speech itself. $^{402}$ The United Foods Court insisted that it could not uphold "compelled subsidies for speech in the context of a program where the principal object is speech itself., ${ }^{, 403}$ In other words, compelled speech problems arise where the purpose of the compelled payment is supporting speech, but do not arise where the primary purpose is nonexpressive; this contradicts Professor Jacobs' model. The outcome in Southworth, and other cases of funding public forums, cannot rest on this rationale.

Our more basic departure from Professor Jacobs should be apparent. Compelled funding of public forums is not, as she argues, immune from objector's challenge because funding speech is the explicit, permissible government objective in collecting the funds to operate the forum. ${ }^{404}$ Her explanation suffers from the same weaknesses as does Justice Souter's explanation. First, an important government interest never has justified compelled expression. ${ }^{405}$ Second, the same government interest in enhancing expression or aiding, some private speakers cannot and would not justify the paradigmatic government compulsion that payers give money directly to a private speaker to be used for that speaker's own private message. ${ }^{406}$

401. Glickman v. Wileman Bros. \& Elliott, 521 U.S. 457, 477 (1997); see supra notes 89-104 and accompanying text.

402. United States v. United Foods, Inc., 533 U.S. 405, $412-17$ (2001); see supra notes 105-112 and accompanying text.

403. See United Foods, 533 U.S. at 415.

404. See Jacobs, supra note 11, at 470; Jacobs, supra note 7, at 176.

405. See supra notes $372-375$ and accompanying text.

406. See supra notes 376-379 and accompanying text. 
The funding of public forums must be immune from objector's challenge for a different reason. No private expression is funded with the compelled fees, taxes, or payments. Where a public forum, physical or metaphysical, on-campus or in the community at large, is funded, payers give money to a government agency, not to any private speaker, and the payers fund only the forum itself, the physical place, the pot of money, and associated services, none of which are expressive. The payers do not fund the private speech that ultimately occurs in or through that forum. Their free speech interests have not been impinged and their free speech rights have not been triggered.

\section{CONCLUSION}

The Southworth Court's reasoning carried it to a correct decision. But that reasoning leaves just enough room for potential plaintiffs to wreak havoc with similar university student activities fund programs, as well as with all manner of public forums, physical and metaphysical, subsidy programs, streets, sidewalks, parks, and auditoriums, on- and off-campus. Whether such challenges arise remains to be seen. But that does not obviate the need to establish a more proper and workable analytical model.

Under a more proper model for addressing objecting payer challenges to funding public forums, the Court should reject the plaintiffs' claims because the compelled-expression doctrine does not extend to situations in which individuals pay money to a government body for a nonexpressive expenditure, such as maintaining a public forum. Such an approach would be most consistent with the theory and doctrine underlying the protection from compelled expression; it places acceptable, and necessary, limits on how far objecting payers' interests go, while not destroying the vital protections against compelled expression. Most importantly, this model preempts future challenges to public forums and other government programs designed to promote, enhance, and facilitate public discourse that do not involve the direct, compulsory funding or support of private expression. 
**** 